\title{
KUML 2020
}
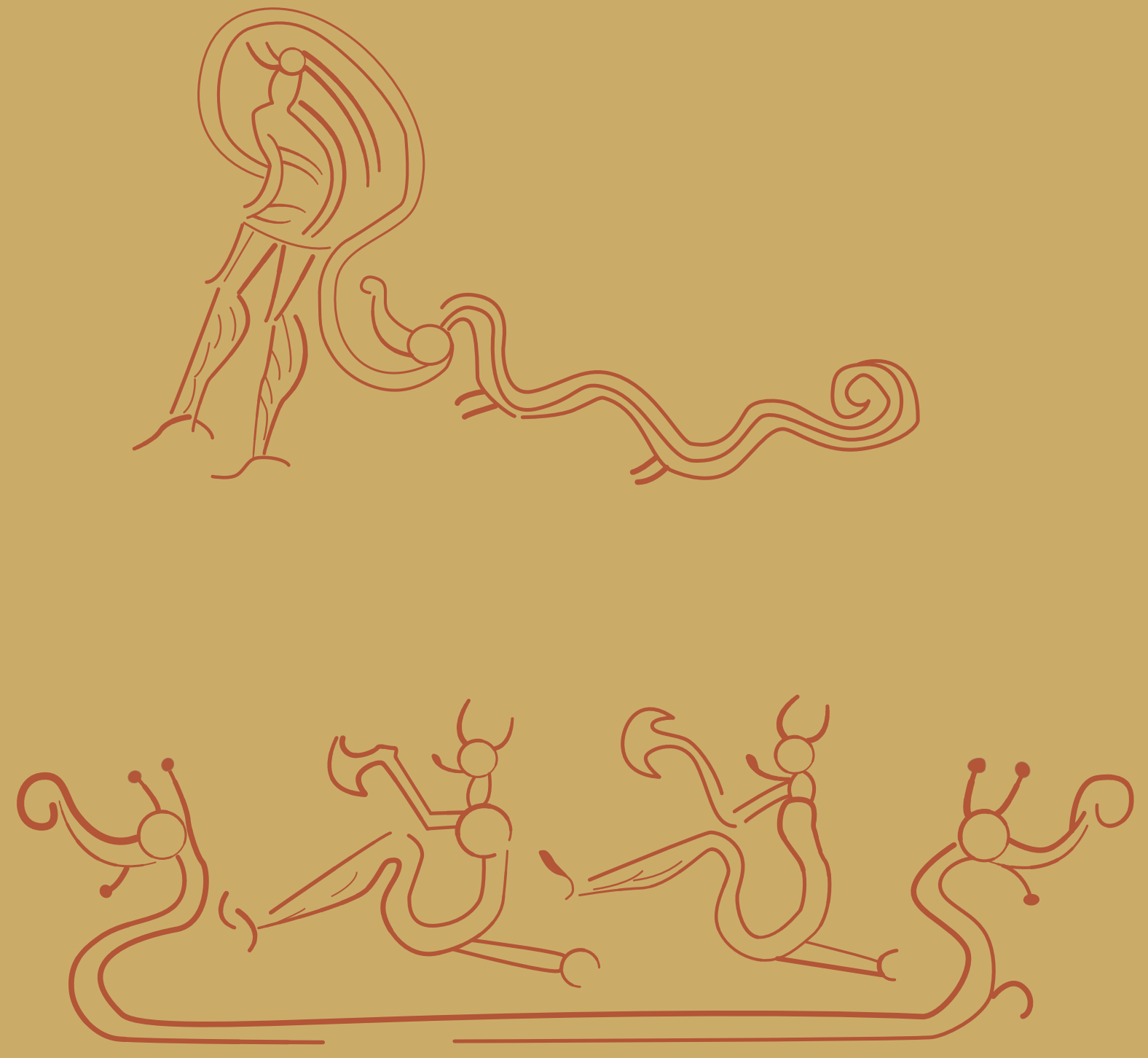


\section{KUML 2020 \\ Årbog for Jysk Arkæologisk Selskab}

With summaries in English

I kommission hos Aarhus Universitetsforlag 


\section{Frie og ufrie bønder \\ Landsbyer, gårde og socialstruktur på den jyske vestkyst i la longue durée}

Målet med denne artikel er - med udgangspunkt i Sydvestjyske Museers udgravninger i Esbjerg Kommune - at arbejde på tværs af periodeskellet imellem forhistorie og middelalder til fordel for et mere kontinuitetsbåret blik på det agrare landskab og de bønder, der skabte det. Hvordan er den overordnede udvikling i bebyggelseshistorien i de to årtusinder fra landsbyernes opståen i førromersk jernalder og frem til den første præcise kortlægning på matrikelkortene fra omkring år 1800? Løber der en rød tråd igennem bebyggelseshistorien i de to årtusinder fra landsbyernes opståen i førromersk jernalder og frem til den første præcise kortlægning på matrikelkortene fra omkring år 1800? Og hvad er de gennemgående træk i det lange tidsperspektiv, la longue durée? Blikket for samspillet mellem bl.a. økonomiske og sociale faktorer over lange tidsrum, er især kendetegnende for Annales-skolen, i dens bestræbelser på at blotlægge og forstå de grundlæggende samfundsstrukturer. ${ }^{1}$

En anden problemstilling, som vil blive diskuteret, er, i hvilket omfang de naturligt forløbende landskabs- og klimaforandringer havde indflydelse på samfundet? Og hvordan er forholdet mellem disse ikke-menneskeskabte processer i forhold til de menneskeskabte? Hvordan blev det agrare landskab påvirket af teknologiske landvindinger som muldfjælsplove og vandmøller eller sociale forandringer som fremkomst af kongemagt og kirke og de hermed forbundne økonomiske byrder?

I artiklens anden del rettes blikket mod den middelalderlige landbebyggelse og mere specifikt relationen imellem de middelalderlige gårdes arkitektur - toften og bygningernes størrelse, konstruktion og fremtoning - og det samfund, gårdene indgik i. I hvilket omfang er det muligt at koble de fåtallige skriftlige kilders omtaler af bønder, bryder, landboer, gårdsæder, fæstebønder m.m. med de arkæologiske levn af bøndernes levesteder? Og hvad skal man lægge i begreberne "frie" og "ufrie" bønder? 
Det er et hovedsynspunkt i teksten, at de arkæologiske undersøgelser i det agrare landskab igennem de seneste årtier har nået et omfang og antal, som muliggør, at også de overordnede sociale modeller for jernalderens, vikingetidens og middelalderens samfund kan holdes op imod udsagnene fra de udgravede levn. Og denne sammenligning peger i retning af en meget stærk kontinuitet, hvor landsbyer bestående af jævnstore familiebrug befolket af relativt frie bønder udgjorde den dominerende gruppe i samfundet helt fra jernalderen og frem til tidlig moderne tid.

\section{Landskab, klima og katastrofer}

Den jyske vestkyst udgør i dag et varieret landskab, som veksler fra Vadehavets udbredte marskdannelser i syd til udligningskyster med aktiv kysterosion i nord. Denne udvikling er slået igennem i de seneste århundreder, mens forholdene i jernalder, vikingetid og middelalder (500 f.Kr.-1500 e.Kr.) var væsentligt anderledes. ${ }^{2}$ Som de seneste årtiers forskning med stadig større sikkerhed har kunnet fastslå, har heller ikke klimaet været konstant, men derimod gennemgået forskellige forandringer med væsentlige implikationer for menneskets mulighed for at sikre sig et udkomme ved landbrug. Særligt to klimaperioder synes at have haft negativ indvirkning på levevilkårene. Den senantikke lille istid, (536-ca. 660 e.Kr.) (Late Antique Little Ice Age, LALIA), som var forårsaget af voldsomme vulkanudbrud, der udspyede så meget aske i atmosfæren, at solens indstråling blev markant forringet i lang tid derefter. ${ }^{3}$ Virkningen blev forstærket af, at solaktiviteten i samme periode var forholdsvis lav, og oven i det hele ramtes i hvert fald dele af Europa også af den såkaldte justinianske pestepidemi, men om denne nåede Skandinavien vides endnu ikke.

Den næste klimakrise var den mindre voldsomme, men betydeligt længerevarende lille istid (Little Ice Age, LIA), hvis effekter særligt påvirkede Danmark i 15-1700-årene. ${ }^{4}$ Klimaet imellem disse to perioder (Medieval Warm Period, MWP) var til gengæld gunstigt og er først i de seneste år overgået af nutidens stigende temperaturer.

Dannelsen af marsken, det vil sige frugtbare, græsklædte kystenge bestående primært af marint aflejret ler, indledtes ved den jyske vestkyst i bronzealderen som følge af en aftagen i havets stigningstakt (fig. 1). Marskengene kunne understøtte et stort dyrehold, primært får/geder og kvæg, og i ældre jernalder var der dannet så udstrakte marskflader, at man på kanten til det højereliggende, tørre land, geesten, som består af bakkeøer og hedesletter, kan iagttage en kraftig vækst i antallet af bebyggelser. Denne tætte, agrare bebyggelse præger Vadehavsområdet i de følgende to årtusinder frem til den moderne periode. 


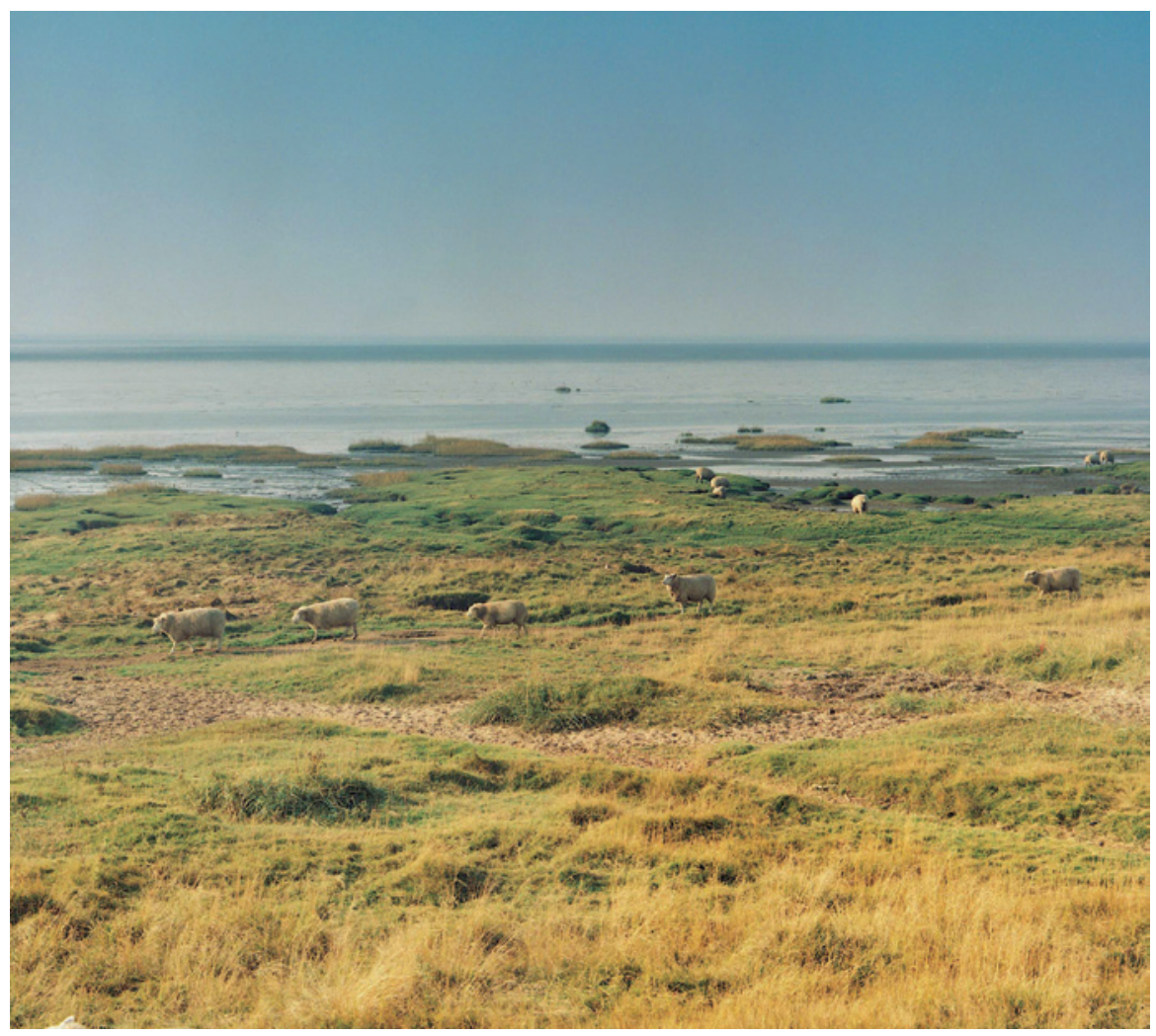

Fig. 1. Marsken ved Novrup øst for Esbjerg. - Efter Siemen \& Stoumann 1996.

Coastal marshland at Novrup, east of Esbjerg.

Når de successivt voksende marskflader nåede et omfang, så de ikke rationelt kunne udnyttes fra den højere liggende geest, flyttede bønderne ud i marsken og anlagde deres gårde på værfter. I det nuværende Danmark anlagdes kun værfter i Ballum- og Tøndermarsken, men på de langt større marskflader længere ned langs kysten i Nordfriesland og Ostfriesland er det kystnære bebyggelsesmønster helt præget af værfter. Generelt bliver de ældre og ældre, jo længere man kommer mod syd, hvilket afspejler marskens dannelseshistorie - altså tidspunktet, hvor marsken de pågældende steder havde nået et omfang, som krævede udflytning.

En anden væsentlig faktor i marskens dannelseshistorie er den landsænkning, det såkaldte vippelinjefænomen, som er en afledt effekt af afsmeltningen af den seneste istids ismasser over den Skandinaviske halvø. ${ }^{5}$ Sænkningen betyder i praksis, at Ribeområdet er sunket omkring $1 \mathrm{~m}$ i det seneste årtusind. Det vil sige, at den øverste meter marskdannelse er dannet siden da. For det 
tørre land betyder det, at det, som i år 1000 var kote $3 \mathrm{~m}$ over havet, i dag er kote $2 \mathrm{~m}$ over havet. Med andre ord er hele landskabet gradvist blevet mere og mere eksponeret for havets oversvømmelser. Det er den store baggrund for de historisk kendte stormfloder, hvoraf "den store mandedrukning” i 1362 er den bedst kendte, og antagelig også værste. ${ }^{6}$ Der er ikke meget, som tyder

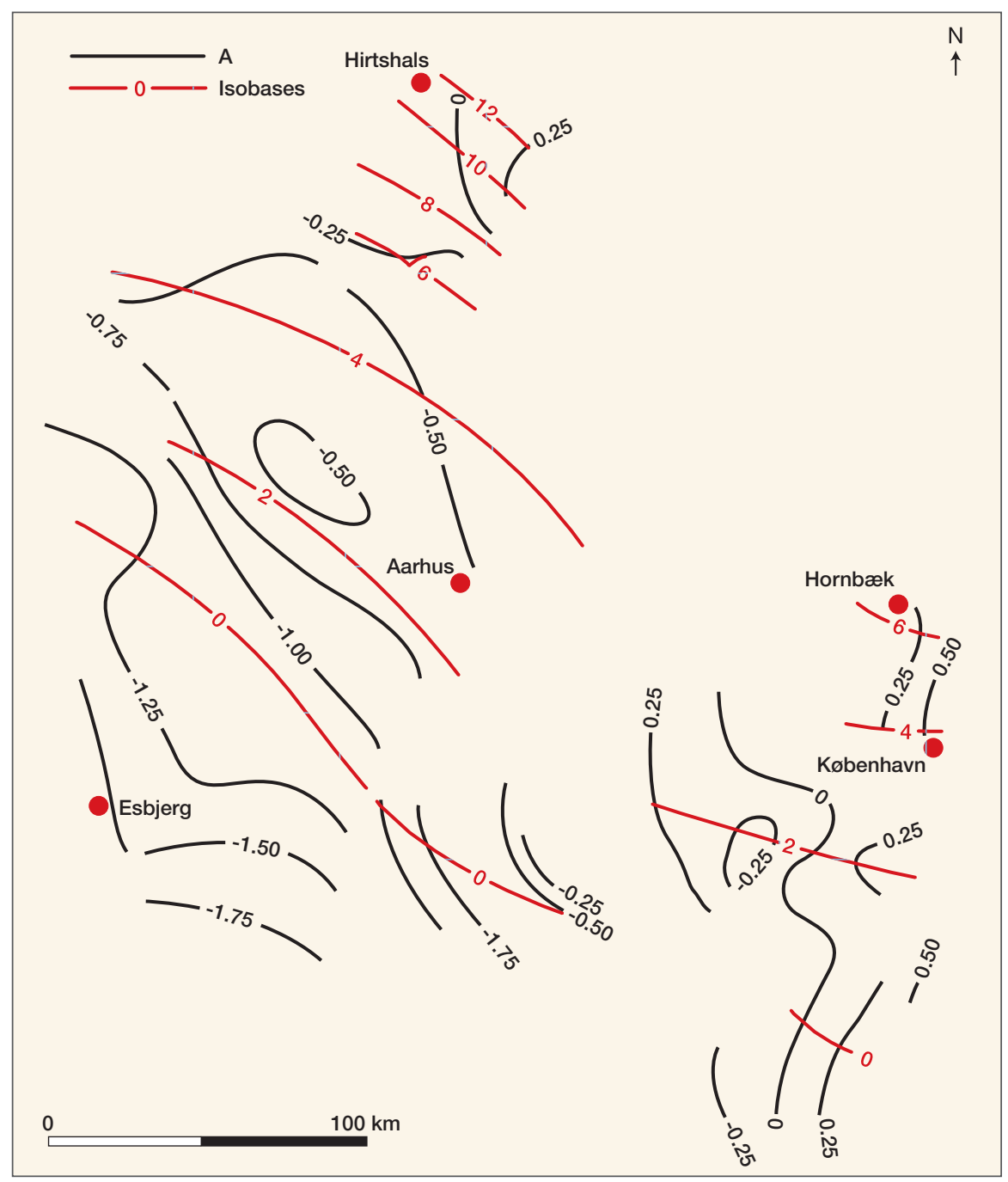

Fig. 2. Linjerne med rødt er isobaser, som viser den anslåede landhævning siden stenalderen i meter. De sorte linjer viser målte niveauforandringer i mm/år gennem de sidste 100 år. $1 \mathrm{~mm}$ om året bliver således til $1 \mathrm{~m}$ på et årtusinde. - Efter Møller 2000.

The red contour lines are isobases showing the inferred rise in land level in metres since the Stone Age. The black lines show measured changes in land level in millimetres per year over the last 100 years. $1 \mathrm{~mm}$ per year will give $1 \mathrm{~m}$ over a millennium. 
på, at stormfloder har udgjort et problem i tiden før højmiddelalderen. Landsænkningen er årsagen til, at der i Tøndermarsken kan findes hustomter helt nede i kote $1 \mathrm{~m}$, omkring Ribe kendes de ned til omkring kote $2 \mathrm{~m}$, mens de omkring Ho Bugt ikke findes under kote $4 \mathrm{~m}$ (fig. 2).

Marskdannelserne strakte sig tidligere meget længere mod nord end i dag. Søkort fra 1500-årene afbilder en Vadehavslignende vestkyst helt op til Nissum Fjord, men nord for Ho Bugt er de tidligere marskenge i vidt omfang dækket af sandflugt, som i århundrederne efter middelalderen var en plage for områdets bønder.?

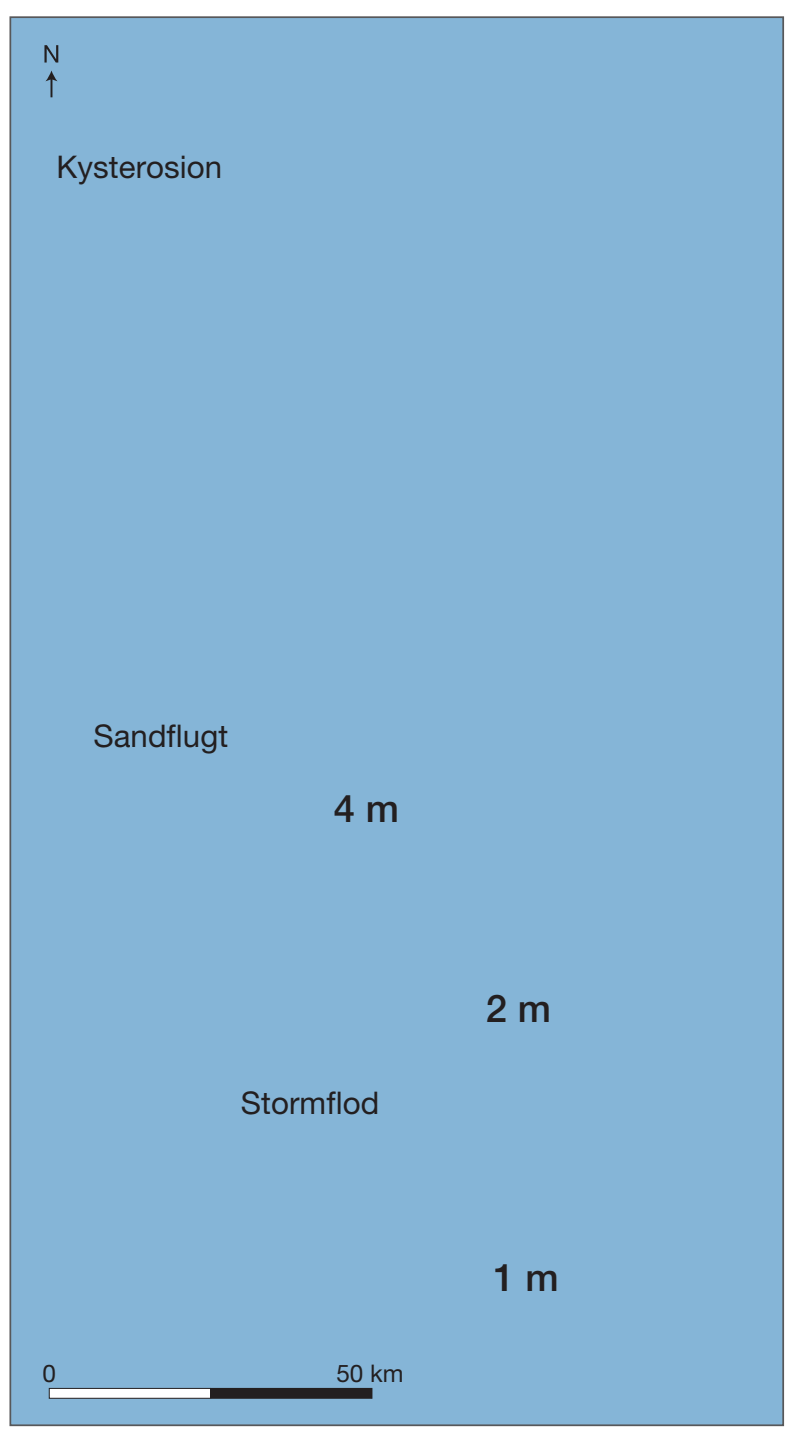

Fig. 3. Den jyske vestkyst er et foranderligt landskab, som i historisk tid har været udfordret af både stormfloder, sandflugt og kysterosion. Udbredelsen af disse fænomener forklares for en stor dels vedkommende af isostatiske ændringer. De lavest kendte bosættelsesniveauer i marsken er desuden markeret. Kort af forf.

The west coast of Jutland is a dynamic landscape that has undergone radical changes during the last millennium due to floods, sand drift and coastal erosion. The geographical distribution of these phenomena is intricately linked to isostatic changes. The lowest known settlement levels in the marshland areas are marked in metres above sea level. 
Det Horns Rev, som har lagt navn til flere herreder, er i dag kun en undersøisk forekomst, men må på navngivningstidspunktet have været synligt og fungeret som en enorm bølgebryder, hvis nedbrydning antagelig var en forudsætning for dannelsen af den nuværende udligningskyst.

Nord for Nissum Fjord finder der aktiv kysterosion sted, hvis omfang ud fra kirkestrukturen kan anslås at have opslugt omkring $1 \mathrm{~km}$ land, siden kirkerne blev bygget i ældre middelalder (fig. 3).

Som det fremgår, har landskabsudviklingen på den jyske vestkyst været dynamisk. På den sydligste del af halvøens vestkyst har landsænkningen betydet, at store marskflader og de her liggende bebyggelser er helt eller delvist gået under i stormfloder, og af samme årsag er det kystnære landskab præget af digebyggerier, landvindingstiltag og bebyggelse på værfter. Imellem Ho Bugt og Nissum Fjord har "Den lille istids" sandflugt i vidt omfang opslugt marskengene og forringet områdets agrare potentiale, og i endnu højere grad er dette naturligvis tilfældet længere mod nord, hvor havet æder af landet. Fælles for alle forandringerne er, at de på hver deres måde har forringet livsvilkårene i kystzonen, som i middelalderen og før endnu må have været væsentligt mere gunstige end senere.

Kirkelisten i kompendiet Ribe Oldemoder, hvis affattelse dateres til omkring 1325, rummer en komplet liste over stiftets kirker samt med angivelse af den afgift, hver kirke skulle svare til bispestolen, antagelig i forbindelse med sysselprovstens årlige visitats. ${ }^{8}$ Landsognenes afgifter er gradueret imellem to og otte skilling sterling, og med udgangspunkt i listens kirker er det muligt at rekonstruere et præcist sognekort over Ribe stift og sætte afgiften i forhold til sognets størrelse. På den måde dannes et økonomisk kort over Ribe stift fra omkring 1325 - altså tiden før forværringerne, som de voldsomme stormfloder og den lille istids sandflugt førte med sig. ${ }^{9}$ Ved denne kortlægning fremstår hele den vestjyske kystzone, som betaler af en afgift, der i niveau svarer til niveauet på Østjyllands fede lerjorder (fig. 4).

Kystzonens afgiftsniveau svarer fint til samme områdes rige bestand af store og fint udstyrede romanske kirker, hvilket antyder, at den relative velstand $\mathrm{i}$ hvert fald rækker tilbage til kirkebyggeriets tid i 11- og 1200-årene.

En historisk kendt katastrofe, som må have haft en markant indflydelse på skabelsen af fortidsminder, er den sorte døds hærgen i $1350 .{ }^{10}$ Hvis denne epidemi, som antaget, slog halvdelen af landets indbyggere ihjel, må det have betydet, at en enorm mængde både bygninger og andre akkumulerede ressourcer var tilgængelige $\mathrm{i}$ landskabet $\mathrm{i}$ lang tid fremover. Overflødige bygninger kunne levere både byggematerialer og brændsel i årtier. Gode agre lå ubenyttede hen, stævningsskovene bugnede, og utallige husdyr havde ikke længere en ejer. Det må have lettet arbejdet med at sikre sig føden for de overlevende, og forbruget af 


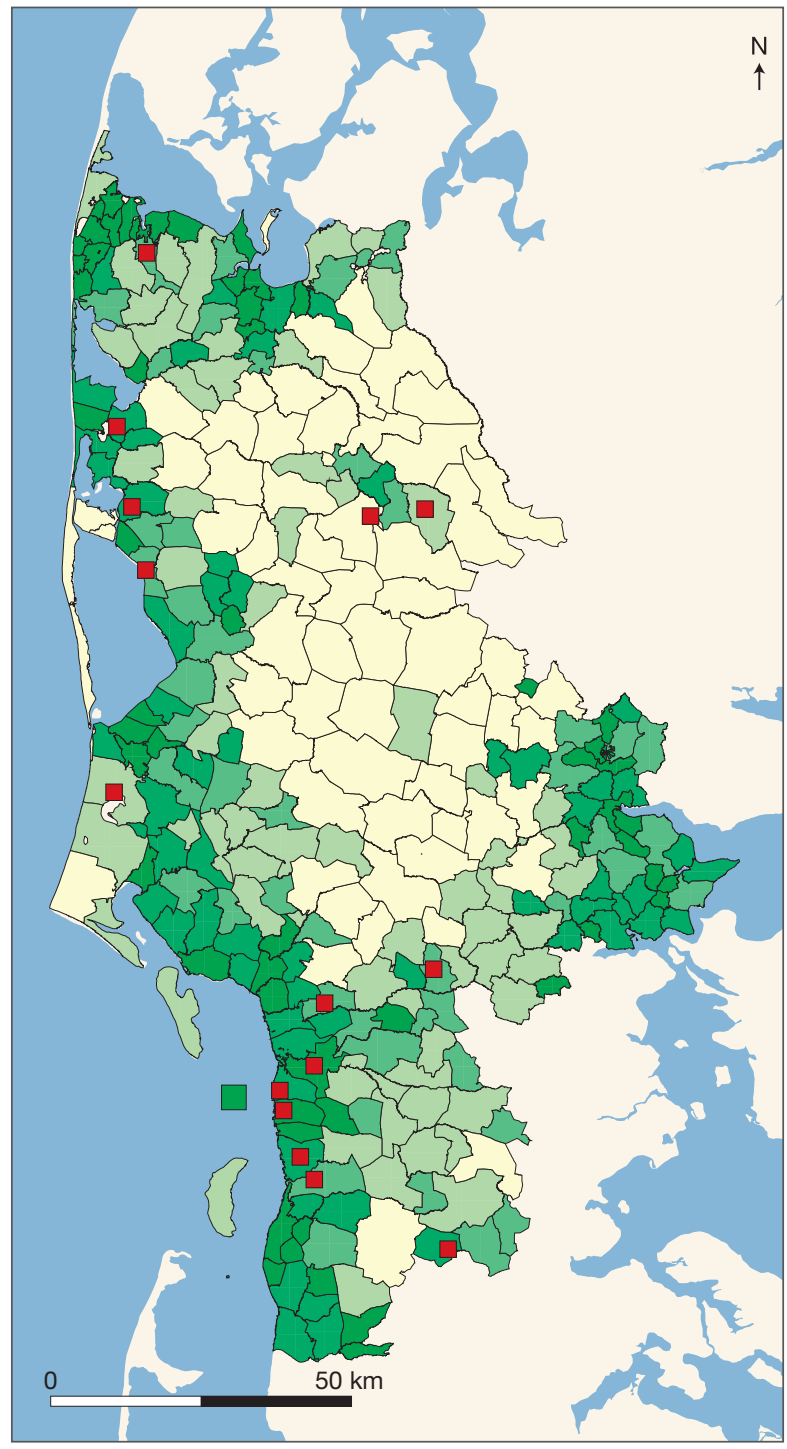

Fig. 4. Sognekort over Ribe stift på baggrund af kirkelistens oplysninger. De enkelte sognes afgiftsniveau er sat i forhold til sognets areal. Lysgule farver viser den laveste afgiftsprocent, mens de mørkgrønne viser den højeste. Som det fremgår, har hele den vestjyske kystzone svaret afgifter på niveau med de østjyske morænelandskaber, formodentlig som afspejling af en tilsvarende befolkningstæthed. Med rød prik er angivet kendte romanske kirketårne. - Kort og databehandling af forf.

Map showing the dues of the individual parishes adjusted according to the size of the parish. The light yellow zones show the lowest proportional yield while the dark green ones show the highest. As can be seen, the whole of the coastal zone of western Jutland was responsible for returns at the same level as the moraine landscapes of eastern Jutland, presumably reflecting a similar density of population. The red dots mark the known Romanesque church towers.

hele denne opsparede pukkel af ressourcer kan være én årsag til det svage arkæologiske aftryk af den senmiddelalderlige gård ud fra devisen, at færre mennesker med flere allerede tilgængelige ressourcer betyder færre arkæologiske levn.

I forhold til brugen af jordgravede stolper i byggeriet synes der at kunne iagttages en sammenhæng. Generelt var der i hele oldtiden og frem til højmiddelalderen rigelig adgang til tømmer i hele Sydvestjylland. Det bruges i udstrakt og ikke økonomiserende grad til huse, hegn og brønde, og egetræ synes at have været næsten enerådende. 
I højmiddelalderen ser de jordgravede stolper ud til at gå ud af brug, men i 16. århundrede genoptages skikken. ${ }^{11}$ Bag dette mønster kan skjule sig det forhold, at presset på skovene øgedes i takt med den middelalderlige varmeperiodes befolkningstilvækst, indtil der ikke var mere tilgængeligt tømmer. Efter pestens hærgen lettedes presset, og skovene kom sig i et sådant omfang, at de igen kunne udnyttes, lige indtil de igen var mere eller mindre fæeldede.

\section{Jernalderens og vikingetidens bebyggelse i Vestjylland}

I takt med det voksende antal og omfang af arkæologiske udgravninger, synes det i stigende grad klart, at oldtidens og i særdeleshed jernalderens bebyggelse var mere udbredt og omfattende, end nogen havde turdet gætte på. ${ }^{12}$ Det samme indtryk understøttes af metalfundene, som Danmarks mange detektorbrugere indleverer i tusindvis af til museerne. Isoleret betragtet udgør de løsfund, men de færreste vil være uenige $i$, at det altovervejende flertal af detektorfundene fra et givet ejerlav også er genstande, hvis brugsliv udspillede sig i det pågældende ejerlav. ${ }^{13}$

De seneste årtiers enorme tilvækst af data om forholdene i oldtiden er kun $\mathrm{i}$ meget beskedent omfang analyseret og publiceret, hvorfor den følgende fremstilling af forholdene rummer visse impressionistiske træk, som fremtidige arbejder må vurdere holdbarheden af.

I Esbjerg Kommune er der siden 1970'erne udført serier af meget omfattende fladeudgravninger, som omfatter flere hele landsbyer og ejerlav. Kun et fåtal af disse undersøgelser er publicerede i større eller mindre grad, men de udgør alligevel i arkæologisk forstand det uden sammenligning mest intensivt undersøgte område langs Jyllands vestkyst. ${ }^{14}$

Igennem de senere år har museet målrettet arbejdet på at digitalisere og georeferere de xldre udgravninger for at skabe et detaljeret, opdateret og komplet billede af udgravningsaktiviteten og dens resultater (fig. 5). Omkring Ribe er omfanget af fladeudgravninger relativt begrænset, og de, som er udført, er generelt små. Til gengæld er der kendskab til et meget stort antal bebyggelser både fra luftfotos, læhegnsrekognosceringer og detektorbrug.

Fra førromersk jernalder og fremefter kan der i Esbjerg Kommune dokumenteres en markant koncentration af bebyggelse i kystzonen, som antagelig afspejler en befolkningstilvækst, der blev til på baggrund af marskens dannelse og de hermed forbedrede græsningsmuligheder for dyr. Bebyggelsen i ældre førromersk jernalder var generelt små gårde, oftest énfasede, der flyttede rundt i landskabet, som det var typisk for perioden. ${ }^{15}$ I yngre førromersk jernalder 


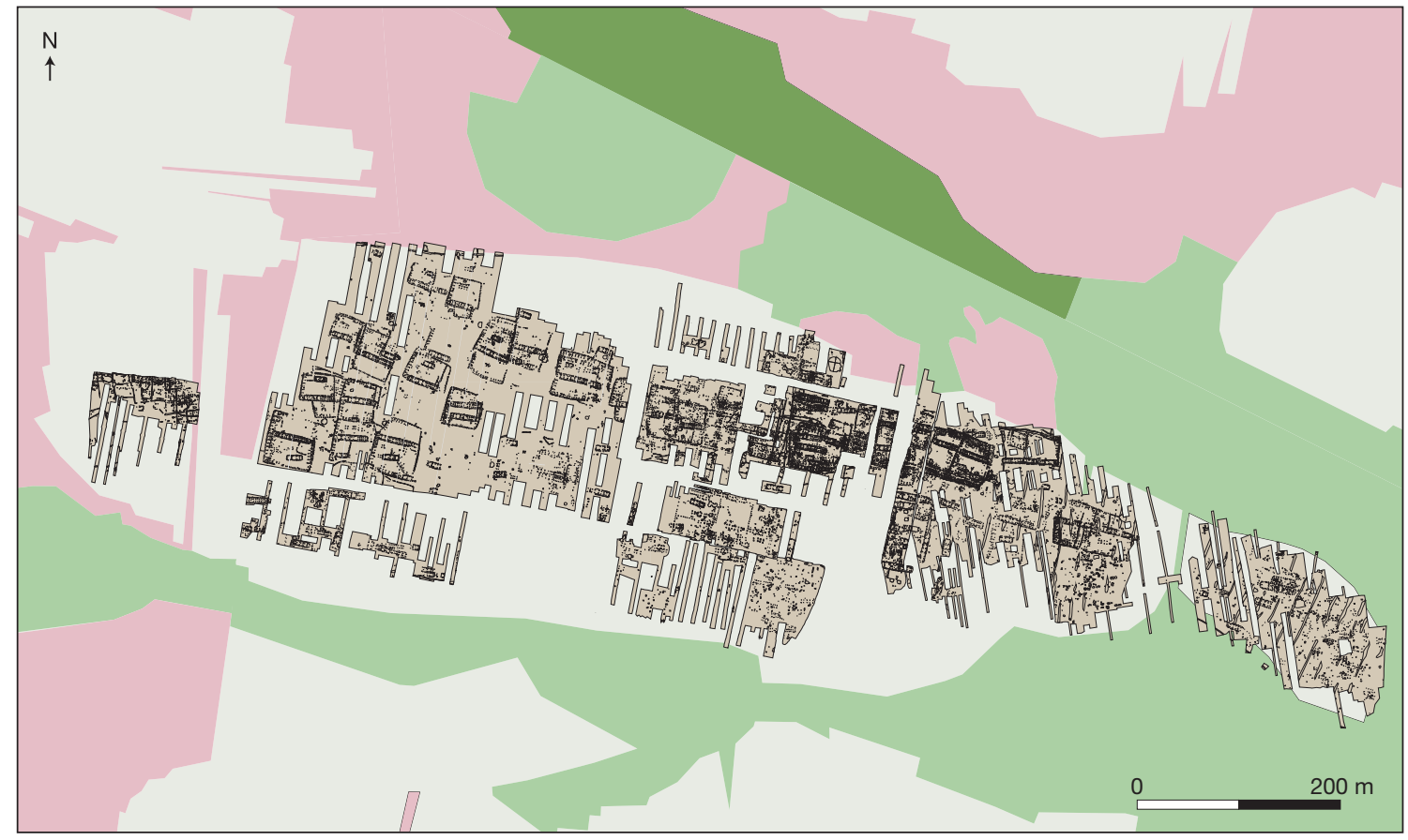

Fig. 5. De omfattende udgravninger i ejerlavet Uglviggård i Jerne sogn v. Esbjerg (se fig. 6). Der er undersøgt flere faser af en landsby, som af udgraveren blev anslået til at bestå af 3-5 gårde. Den vestligste fase er dateret til 4. årh., og længere mod øst er undersøgt både ældre og yngre faser af samme, mindre torp-landsby. Udgravningerne ESM 1661 og ESM 1697 Grønnegård samt ESM 1698 Tovrup.

The excavations at Uglviggård in Jerne parish, east of Esbjerg (cf. fig. 6). Several phases of a small village consisting of three to five farmsteads dating from the Late Roman and Early Germanic Iron Ages have been excavated. A typical thorp-type settlement. Excavations ESM 1661, ESM 1697 and ESM 1698.

opstod landsbyerne, hvor flere samtidige gårde lå tæet sammen, og uden at det kan bevises, må man antage, at indgåelse af en form for dyrkningsfællesskab har været ét centralt motiv for den ændrede driftsform. I modsætning til tidligere blev gårdene også mere stedfaste og kunne ligge på samme sted igennem mange faser.

I de følgende 2000 år var landsbyen den dominerende sociale organisationsform. Hele perioden igennem var driftsenhederne i altovervejende grad husstande struktureret som familiebrug, der i dyrkningsfællesskab med andre gårdsenheder udnyttede et naturligt afgrænset landskabsareal. Små ressourceområder kunne rumme enestegårde. Der kan være mindre forskelle på gårdstørrelsen i den samme landsby, men ud fra både gårdenes arkitektur 
og de tilhørende gravpladser er der kun svage vidnesbyrd om eksistensen af for eksempel flere klasser i datidens landsbyer, altså den eventuelle eksistens af en gruppe "ufrie" bønder, som man kunne knytte betegnelserne slaver, trælle, landboere eller husmænd til. ${ }^{16}$ Men der er dog det forbehold, at selv i velundersøgte tilfælde er antallet af grave langt mindre end det antal mennesker, der levede i et givet ejerlav. Til gengæld udviser samtidige bebyggelser en overraskende ensartethed, hvor det er vanskeligt at indplacere en større mulig underklasse.

Men der hersker ikke tvivl om, at der eksisterede et aristokrati og/eller præsteskab, som fra deres gårde varetog (måske primært) sakrale centerfunktioner i forhold til blot, ofringer og de frugtbarhedsritualer, som præger agrart baserede samfund. ${ }^{17}$ Stednavne, markante votivfund og godskoncentrationer fra senere tider udpeger disse lokaliteter, som ofte udviser en forbløffende lang kontinuitet. I Vestjylland tilhører pladser som Dankirke, Dejbjerg og det nyopdagede kompleks i Harreby/Fæsted denne kategori. ${ }^{18}$

I ældre jernalder fremstod markerne som små afgrænsede lodder, som pløjedes med ard, men allerede i romersk eller germansk jernalder synes muldfjælsploven at være slået igennem, og en konsekvens heraf er dannelsen af marksystemer bestående af langstrakte, nogle gange højryggede agre. ${ }^{19}$

\section{Ejerlavenes morfologi og opståen}

Den digitale adgang til de ældste matrikelkort, primært Original 1-kortsættet, betyder, at det i dag er muligt i GIS-miljøer at rekonstruere et meget præcist billede af landskabsudnyttelsen omkring år 1800, før dræning og mekanisering i landbruget tog fart, og sammenligne dette med de langt ældre, udgravede bebyggelser. Sydvestjyske Museer har georefereret hele Original 1-kortsættet for museets ansvarsområde, Esbjerg, Fanø og Billund kommuner og vektoriseret landskabstypen og gårdenes placering. På den måde er dannet et operationelt og uhyre detaljeret kortlag, som viser udbredelsen af agerjord, hede, vådområder, vandløb, søer, skove, lergrave, fortidsminder m.m. samt også mange stednavne (fig. 6).

Ved at betragte denne kortlægning og i første omgang sammenholde ejerlavsgrænserne med landskabsudnyttelsen og -formerne er det tydeligt, at to overordnede principper for grænsedragning synes anvendt. Enten følger skellet en naturlig forekomst som et vandløb eller et vådområde, men hvis ikke sådanne var til stede, forløber skellet i stedet overvejende lineært over længere afstande, for eksempel hedestrækninger, og er placeret i sigtelinjer mellem for eksempel gravhøje. Omkring år 1800 var skelhjørnerne ofte også markeret af 


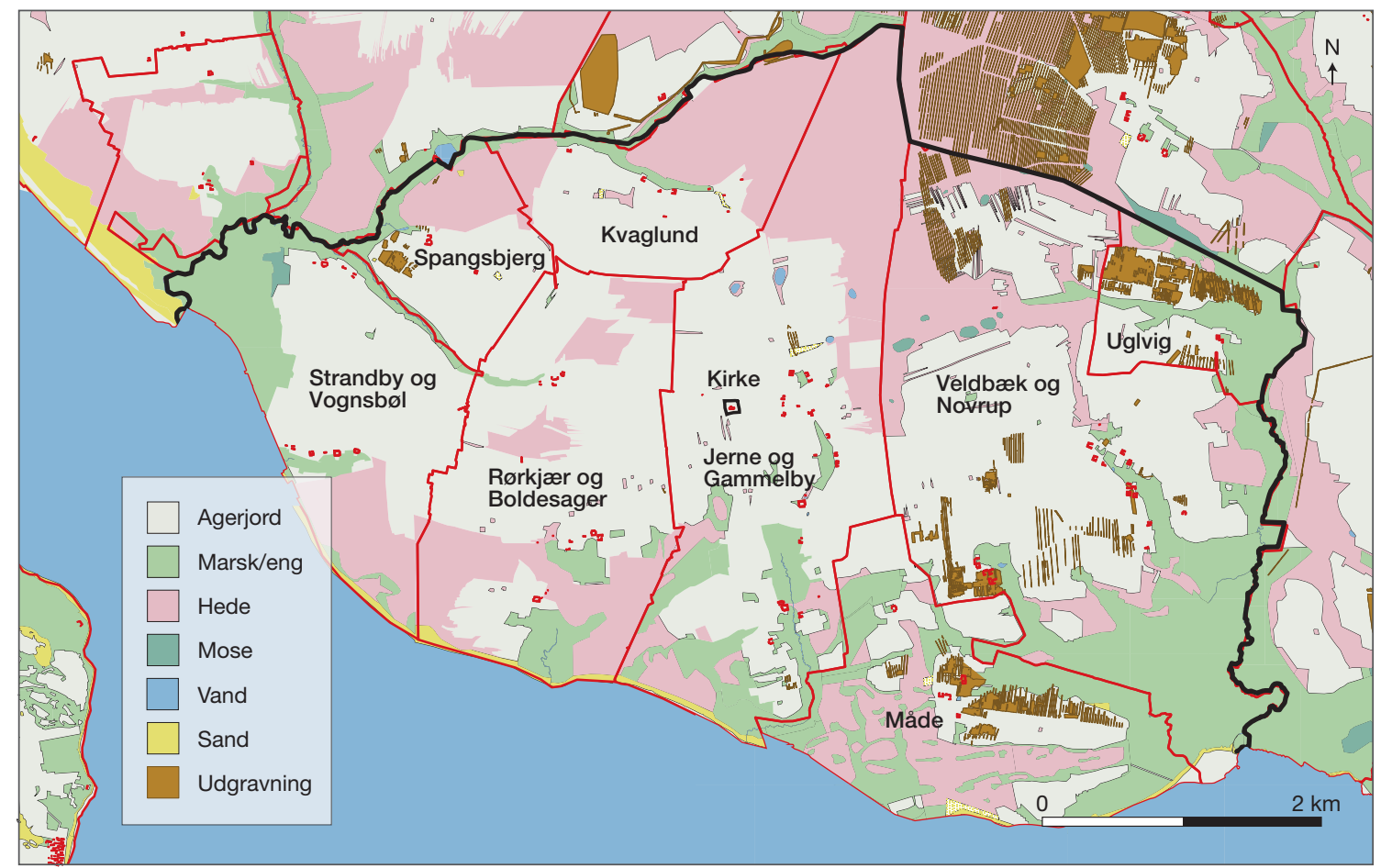

Fig. 6. Jerne sogn under det nuværende Esbjerg. Landskabsudnyttelse, ejerlavsgrænser og bebyggelse efter Original 1-matrikelkortene. Den let bølgede bakkeø er opdelt i mange mindre bebyggelser. Med brunt er udgravningsfelter markeret. - Kort af forf.

In Jerne parish, the clayey and slightly undulating Saalian moraine hill offered numerous minor settlement areas divided by small watercourses and heathlands. The settlement in the area was consequently divided up into many small vills (grey lines). A series of excavations (brown) have shown that this situation extends back to the Iron Age.

sten. Inden for det område, et ejerlav udgør, vil et centralt område udgøres af agerjorden, hvor gårdene ofte ligger nogenlunde i midten, og rundt omkring findes de mere marginale jorder i form af primært hedestrækninger.

Hvis man foretager en diakron sammenligning imellem landskabsudnyttelsen omkring år 1800 og forekomsten af bebyggelse og detektorfund fra jernalder og vikingetid, fremkommer et iøjnefaldende mønster. Både bebyggelse og detektorfund koncentrerer sig meget markant på de arealer, som også var agerjord omkring år 1800, mens hedearealerne har en langt lavere forekomst af fortidsminder og i givet fald kun bebyggelse fra ældre forromersk jernalder og bagud i tid. Ved inddragelse af jordartskortene fra GEUS ${ }^{20}$ synes dette sammenfald ikke at have noget at gøre med undergrundens beskaffenhed. Indtil videre må konklusionen være, at kernen i ejerlavenes agerjord går mere eller 
mindre ubrudt tilbage til landsbyernes opståen. Mens landsbyerne i jernalder, vikingetid og middelalder har efterladt et tydeligt arkæologisk aftryk, er næsten alle synlige spor af de tilhørende marksystemer, som udgjorde grundlaget for fødevareproduktionen, for længst borte. Men skabelsen og vedligeholdet af dem rummer i sig en række selvforstærkende dynamikker, som kunne underbygge den lange kontinuitet. Rydning af marker for sten, gødskning på agerjordene, tørveskrælning på marginaljordene, brug af stævningsskove m.m. er alt sammen investeringer, som tjener til at bevare det én gang etablerede dyrkningssystem, som ikke udgør en konstant størrelse, men kan vokse eller skrumpe i takt med samfundskonjunkturer og befolkningstallets udvikling.

Iagttagelserne fra Sydvestjyske Museers udgravninger omkring Esbjerg tyder på, at ejerlavene i betydningen adskilte dyrkningsfællesskaber med agerjorde omgivet af mere marginale jorde, går mere eller mindre ubrudt tilbage til landsbyernes opståen i yngre førromersk jernalder. ${ }^{21}$ Til gengæld tyder mindre indtil videre på, at de har haft klart markerede grænser. I hvert fald er det endnu ikke lykkedes at påvise jordfaste ejerlavsgrænser fra oldtiden.

\section{Adelbyer og torper}

I landskabslovene, som blev nedskrevet i 13. århundrede, skelnes mellem adelbyer og torper uden nærmere definition af begreberne, men torperne synes at være aflæggere af adelbyerne og kunne stå i en vis form for afhængighedsforhold til disse. ${ }^{22}$ I forskningen generelt sættes grundlæggelsen af torperne i forbindelse med vikingetidens og den tidlige middelalders bebyggelsesekspansion og hermed forbundne udflytterlandsbyer. ${ }^{23}$ Omtalen i landskabslovene viser, at begreberne må have været velkendte i samtiden, og som med ejerlavene kunne man stille spørgsmålet, om denne skelnen også giver mening, når man kigger længere bagud i tid?

I første omgang kan det være vanskeligt at afgøre, om en given landsby er en adelby eller en torp, og om begreberne muligvis også kunne være dynamiske, så tidligere adelbyer under andre historiske rammer kunne blive til torper eller omvendt? Navnestoffet giver et første fingerpeg, og typisk vil adelbyens efterled tilhøre det ældre navnelag, mens torpens enten vil være af gruppen torpnavne eller tilhøre det yngre navnelag. ${ }^{24}$ Andet led i undersøgelsen kunne være at se på administrative inddelinger af religiøs, militær eller juridisk art som sogne, skibener, herreder, birk m.m., hvor landsbyer med disse funktioner tilknyttet oftest også ville være en adelby. Herefter kan man undersøge de enkelte ejerlav. Landskabets muligheder synes mere end noget andet forhold at have dikteret de enkelte ejerlavs størrelse. I den nordlige del af Sydvestjyske Museers ansvars- 


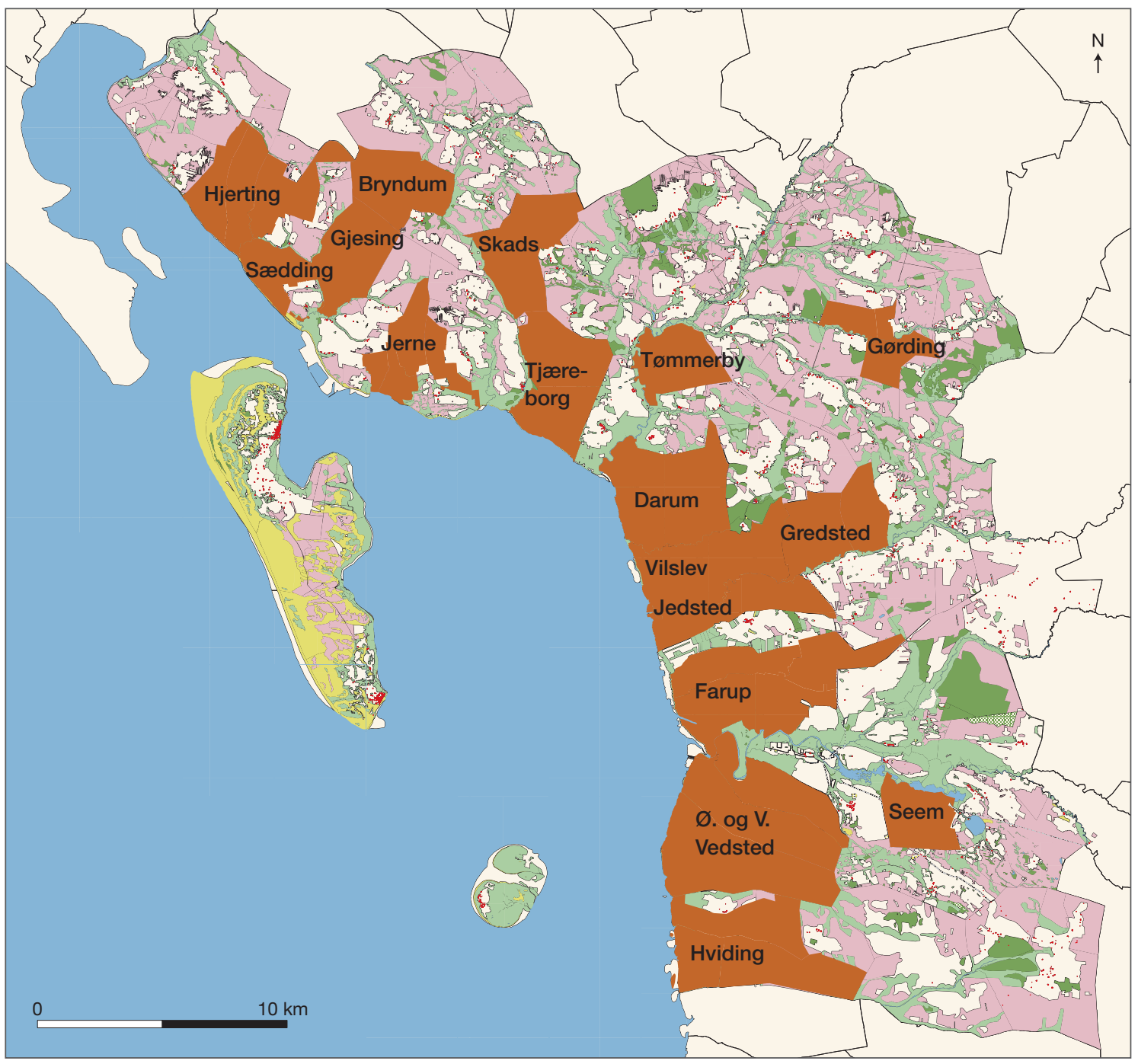

Fig. 7. Kort med tentativ udpegning af adelbyer og deres ejerlav i Esbjerg kommune. Udvalget baserer sig på stednavnestoffet, kendte fortidsminder og topografi. - Kort af forf.

Tentative mapping of main villages (adelbyer) and their vills in Esbjerg municipality, based on place names, archaeological sites and monuments and topography.

område, Esbjerg Bakkeø, har denne gamle moræneflade udstukket rammerne for mange mindre torp-ejerlav, mens den sydlige del af ansvarsområdet, Ribemarsken, har færre naturlige skel og består af færre og langt større landsbyer. Med inddragelse af navnestof, sognestruktur og landskabsformer er en sådan tentativ kortlægning af adelbyer forsøgt på fig. 7. 
Nogle landsbyer fremstår som sikre adelbyer eller torper, mens - afhængig af landskabets morfologi - en større eller mindre gruppe indimellem kan være knap så sikre. Men for Sydvestjyske Museers ansvarsområdes vedkommende afslører analysen også, at landskabsformerne mere end noget andet forhold synes at have været placeringsangivende for de forskellige bebyggelser, og at de mange størrelsesforskelle og variationer har et selvgroet præg.

\section{Eksempler}

Vores viden om jernalderens og vikingetidens bebyggelse baserer sig fortsat i udstrakt grad på de store udgravningskampagner, som Det Arkæologiske Bopladsudvalg under Statens Humanistiske Forskningsråd i 1970'erne gennemførte i blandt andet Hodde, Sædding, Vorbasse og Nørre Snede, men det er fortsat et problem, at særligt nøglelokaliteten Vorbasse, som antages at dække hele tidsrummet fra 3.-11. århundrede, kun er foreløbigt publiceret. ${ }^{25}$

\section{Vorbasse}

I ejerlavet Vorbasse i sognet af samme navn blev et stort areal på omkring 20 ha nord for den historiske landsby udgravet i årene 1974-1987 under ledelse af Steen Hvass. Her fandtes landsbyens forgængere rækkende helt tilbage til 3. århundrede, og på baggrund af udgravningerne formuleredes teorien om den

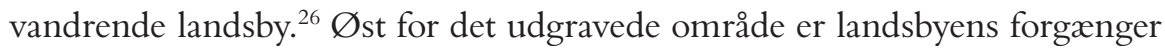
fra ældre romersk jernalder påvist, men ikke udgravet (fig. 8).

Trods hundredvis af andre udgravninger af jernalderlandsbyer har ingen i hverken afdækningsgrad eller bevaringstilstand kunnet matche Vorbasselandsbyen, men bebyggelsesmodellen blev udviklet på et dateringsmæssigt spinkelt grundlag, som baserede sig primært på typologier og stratigrafier.

Vorbasse ligger på den jyske hede i et magert landskab, hvis ydeevne lå langt under for eksempel den vestjyske kystzone, sammenlign fig. 4. Det omfattende ejerlav på ca. $15 \mathrm{~km}^{2}$ omkring år 1800 synes både $\mathrm{i}$ jernalder og tidlig moderne tid ikke at have rummet mere end 6-10 gårde, men alligevel blev Vorbasse kirkested og er klart det største ejerlav i nærområdet. På den måde kan landsbyen klassificeres som en typisk adelby, med lang kontinuitet og flere gårde end nabolandsbyerne, men i et landskab med beskeden ydeevne (fig. 9).

I marskejerlavet St. Darum mellem Ribe og Esbjerg, som også er ca. 15 km², var der omkring år 1800 ca. 50 gårde (fig. 9). Vorbasse udgør altså næppe det gennemsnitlige, men derimod en lille landsby, der formentlig var den vigtigste 


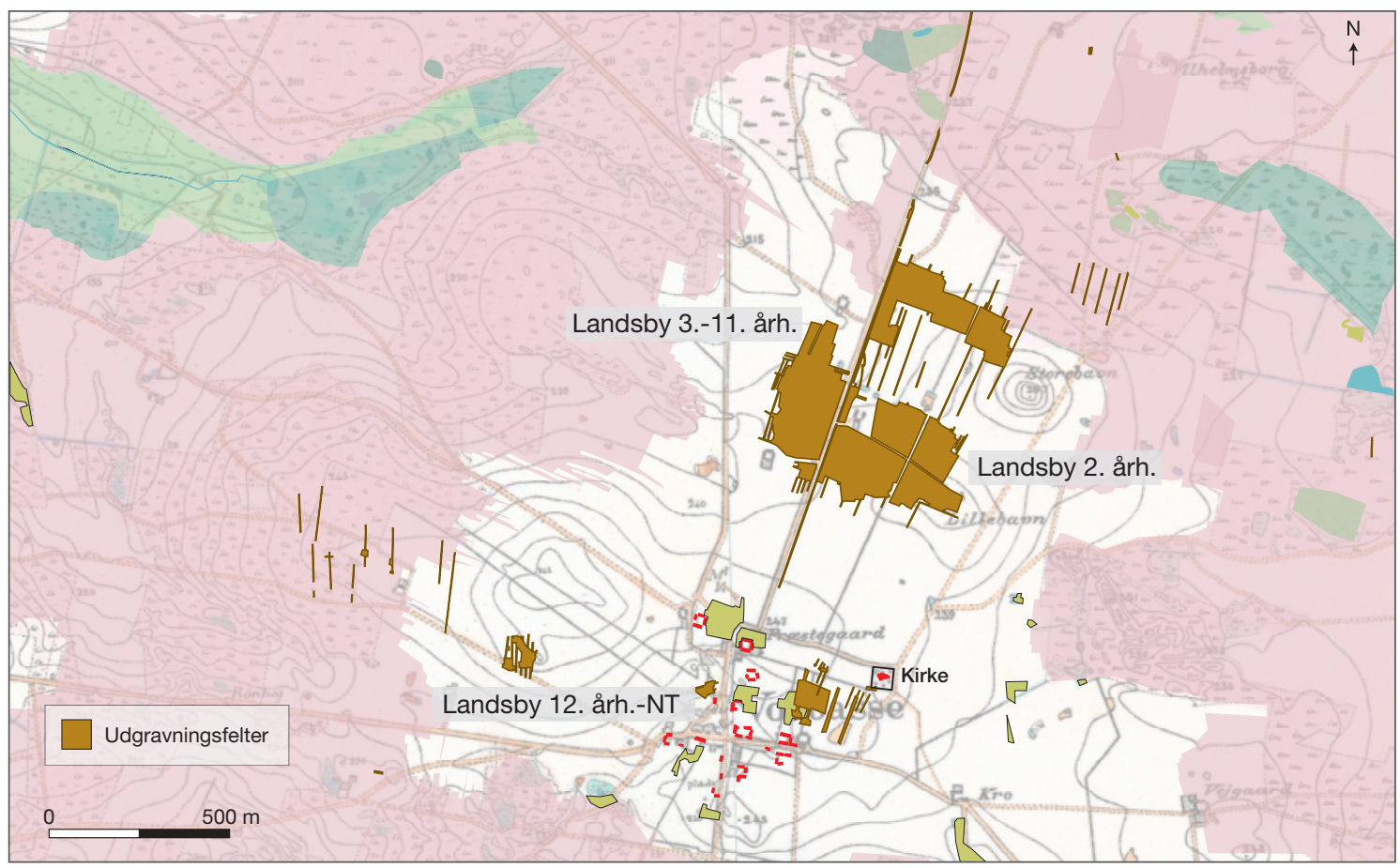

Fig. 8. Udgravninger i Vorbasse med landskabsudnyttelsen fra Original 1-matrikelkortene lagt over De Høje Målebordsblade. - Efter original i Geodatastyrelsen med tilføjelser af forf.

The main village of Vorbasse can be traced through excavations from the Early Iron Age up to the present day. The background map is the first edition $5 \mathrm{~cm}$ map.

indenfor nærområdet. Alligevel optog landsbyen igennem sine forskellige faser megen plads, og strakte sig over flere hundrede meter på hver led, som man er nødt til at udgrave for at forstå strukturen og udviklingen.

\section{Østergaard (Hyrup)}

I ejerlavet Hyrup i Bevtoft sogn imellem Toftlund og Vojens udgravede Haderslev Museum fra 1995 til 2001 et areal på omkring 10 ha kendt som Østergaardudgravningerne navngivet efter en moderne gård i området. ${ }^{27}$ Ejerlavets navn, sognetilhørsforholdet og landskabsmorfologien identificerer landsbyen som en typisk torp, og i forbindelse med undersøgelserne blev netop også udgravet en gård fra sen vikingetid, som delte sig i flere store gårde op igennem 12. århundrede i smuk samklang med periodens generelle bebyggelsesekspansion (fig. 10).

Men denne fase udgjorde langt fra den første bebyggelse på stedet. Også i 8. århundrede lå der en gård på stedet, og endnu før, i 3.-4. århundrede, en 

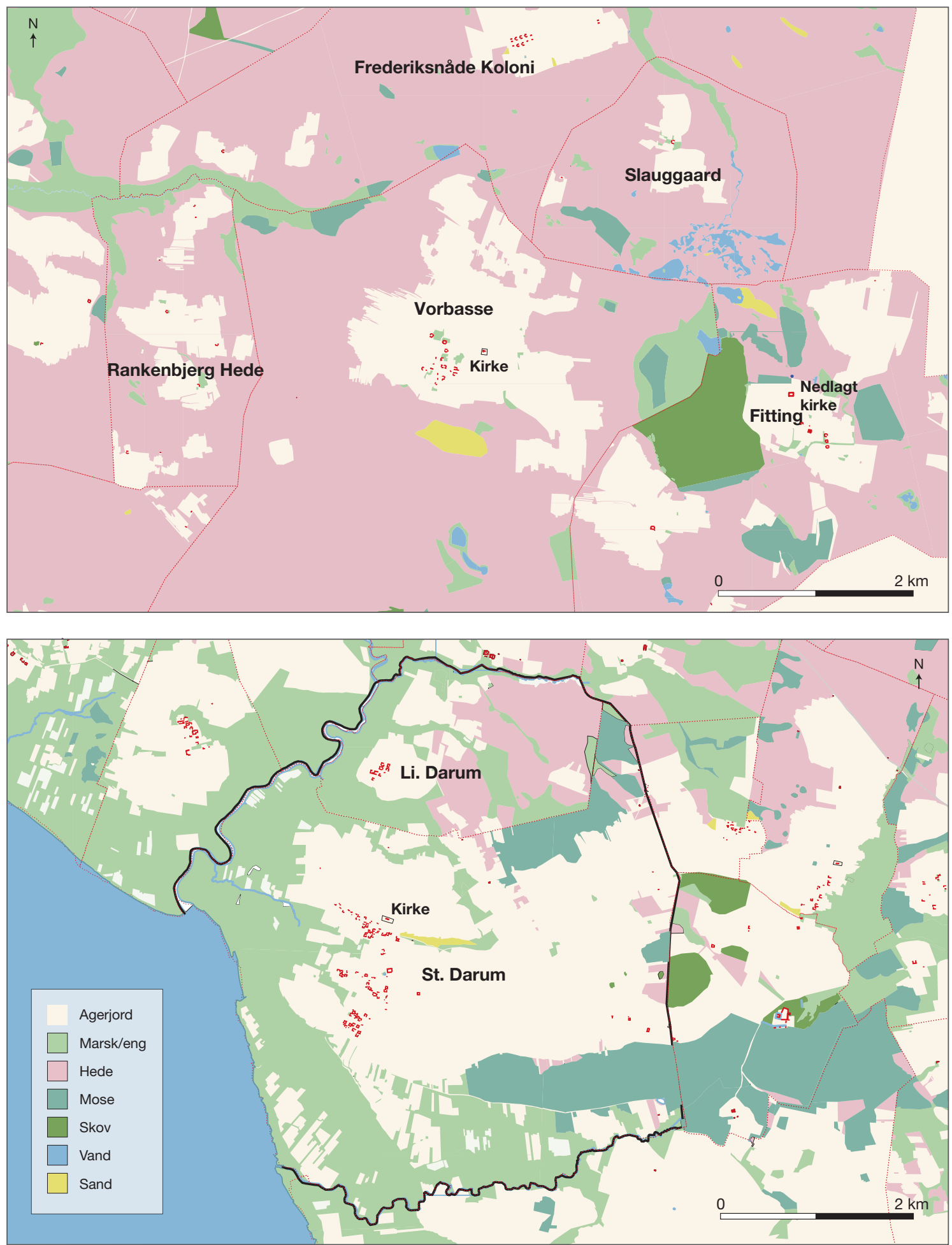
$\leftarrow$ Fig. 9. Landskabsudnyttelse, ejerlavsgrænser og bebyggelse efter Original 1-matrikelkortene i et udsnit af Vorbasse sogn og Darum sogn o. år 1800. Samme målestok. De store forskelle fremstår tydeligt. - Kort af forf.

Land use, vills and settlement in parts of Vorbasse and Darum parishes in c. 1800. Same scale. Major differences are evident in both land use and settlement patterns.

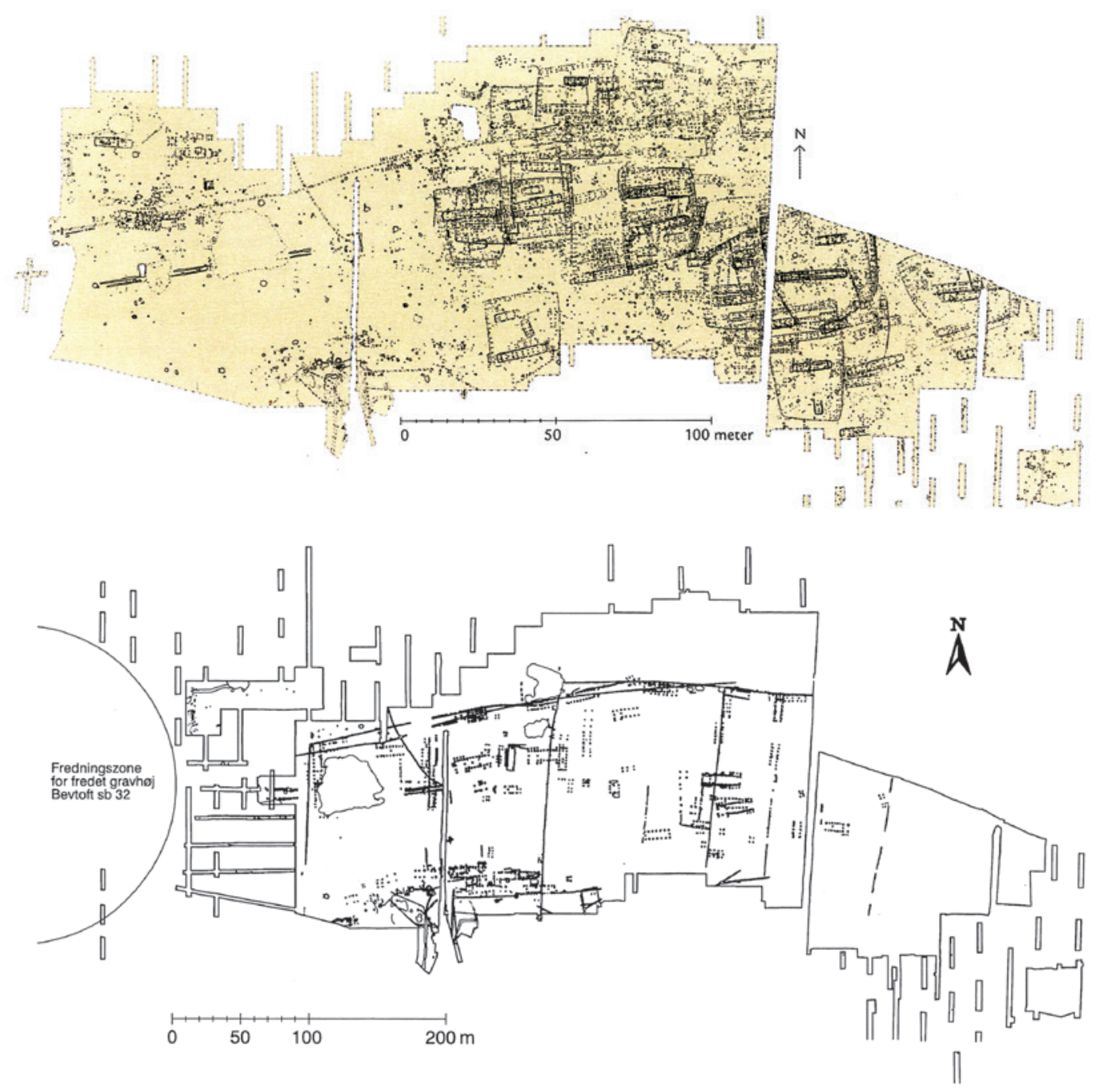

Fig. 10. Jernalder og middelalder i Hyrup. Målestokken øverst er forkert. - Efter Ethelberg 2003 og Sørensen 2002.

The Iron Age and Medieval phases at Hyrup (Østergaard). 
mindre landsby i mange faser. I Hyrup kan således dokumenteres et diskontinuert bebyggelsesmønster, som antyder, at torperne fungerede som bufferzoner omkring adelbyerne, man for eksempel kunne flytte ud til, når der var flere munde at mætte, end adelbyens jorder kunne føde. Og denne rolle synes de at have haft lige siden landsbyernes opståen.

\section{Andrup}

I ejerlavet Andrup i Skads sogn, lidt nordøst for Esbjerg, som i 16- og 1700-årene rummede fire gårde og to huse, har Sydvestjyske Museer siden 2009 gennemført store forundersøgelses- og udgravningskampagner tilsammen omfattende mere end 235 ha. Med tillæg af undersøgelser udført i de tilstødende ejerlav er et areal på over 500 ha blevet systematisk arkæologisk forundersøgt og efterfølgende udgravet (fig. 11). ${ }^{28}$

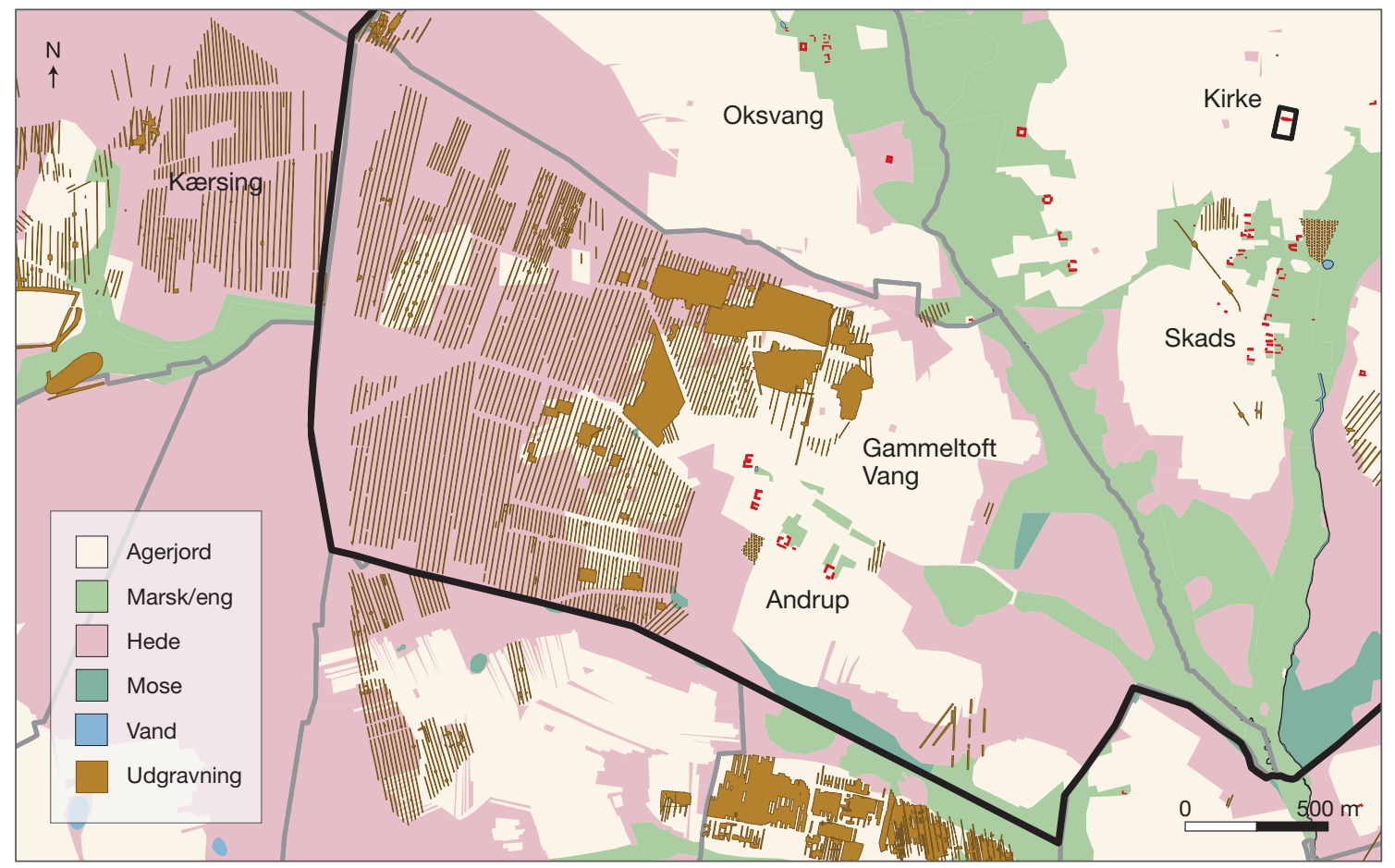

fig. 11. Landskabsudnyttelse, ejerlavsgrænser og bebyggelse i og omkring Andrup efter Original 1-matrikelkortene fra o. 1800. Udgravningsfelter er vist med brun farve. - Kort af forf.

Land use, vills and settlement in and around Andrup in c. 1800. Excavation trenches shown in brown. 


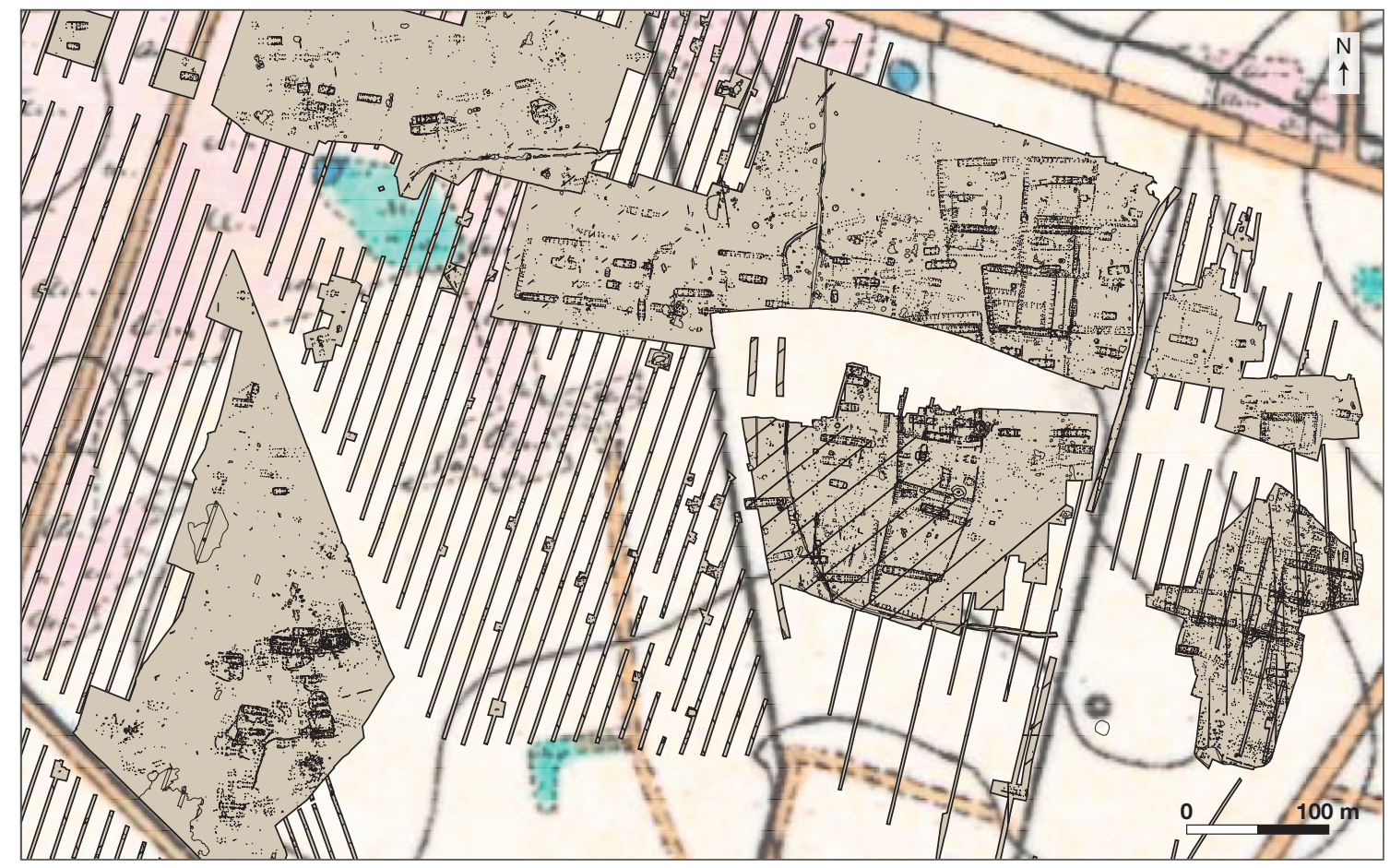

Fig. 12. Oversigtsplan, Andrup med spredte gårde fra førromersk jernalder, en landsby fra yngre førromersk jernalder samt en omfattende landsby fra yngre romersk-ældre germansk jernalder. Landsbyfaserne ligger alle på agerjorden. - Efter original i Geodatastyrelsen med tilføjelser af forf.

Overview of part of the excavations at Andrup, with scattered farmsteads of the Pre-Roman Iron Age, a small village from the Late Pre-Roman Iron Age and a larger village from the Late Roman and Early Germanic Iron Ages. All the village phases are located on what was also arable land in c. 1800.

Både landsbyens navn, antallet af gårde, ejerlavsstørrelsen og sognetilhørsforholdet placerer Andrup som en typisk torp, hvis adelby formentlig er naboejerlavet Skads, der både blev kirkested og herredsby. Den historiske landsbykerne i Andrup er ikke omfattet af undersøgelserne, og et område nordøst for landsbyen, hvor marknavnet Gammeltoft Vang kunne antyde bebyggelse i vikingetid eller middelalder, er desværre i dag dækket af et parcelhuskvartér. Disse forbehold til trods giver udgravningskampagnerne i Andrup alligevel mulighed for at anskue bebyggelsesudviklingen i både detaljer og stor skala.

De overordnede træk i udviklingen svarer til det generelle. I ældre førromersk jernalder lå her énfasede, omflyttende gårde. I yngre førromersk jernalder fortættedes bebyggelsen til landsbyer, som ligger inden for det område, der også omkring år 1800 var agerjord. Fra yngre romersk og æl- 
dre germansk jernalder er undersøgt en kompleks landsbyfase, der udgør en mere omfattende og kompliceret bebyggelse end Vorbasselandsbyen $\mathrm{i}$ samme periode, og de enkelte gårdsanlæg er også væsentligt større i hvert fald i nogle perioder (fig. 12). Den endelige udredning af bebyggelsesfaserne beror på hundredvis af C14-dateringer, som placerer landsbyens højdepunkt i 3.-5. århundrede. En dendrodateret brønd fra 491 e.Kr. udgør det yngste, eksakt daterede element.

Som billedet tegner sig, er der også i Andrup et diskontinuert bebyggelsesmønster, hvor 2. århundrede e.Kr. og yngre germansk jernalder synes fraværende, mens marknavnet Gammeltoft indikerer bebyggelse fra vikingetid eller ældre middelalder. Middelalderens Andrup kan formodes at ligge under den nuværende landsby. Til trods for, at Andrup er et mindre torp-ejerlav på lidt under $5 \mathrm{~km}^{2}$, strækker de udgravede landsbyer sig over mere end $850 \mathrm{~m}$ på den sydvendte bakkeskråning og udgør meget omfattende og komplekse bebyggelser, hvis udvikling kun vanskeligt kan forstås, hvis ikke de udgraves i deres helhed.

Sammenholdt med Sydvestjyske Museers mange mindre udgravninger i ansvarsområdet er der er ikke noget, som tyder på, at Andrup udtrykker andet end den generelle forekomst af bebyggelseslevn i et mellemstort torp-ejerlav i Esbjerg Kommune.

\section{Tjæreborg}

I det store marsk-ejerlav Tjæreborg i sognet af samme navn har Esbjerg Museum igennem årene foretaget en lang række udgravninger, som tilsammen tegner omridset af forholdene i en større adelby. Disse landsbyer var større end torperne og husede også de rigeste bønder, bedømt ud fra forekomsten af rige grave. ${ }^{29}$ Som eksempel på de udfordringer, undersøgelser i disse intensivt bebyggede landsbyer møder, præsenteres her i oversigtsform de udgravninger, museet foretog i tidsrummet 2005-2007 i forbindelse med udstykning af et nyt parcelhuskvartér i umiddelbar tilknytning til den historiske landsby (fig. 13).

Planen taler for sig selv, og den svimlende anlægstæthed og -mængde dækker over intensiv og langvarig bebyggelse igennem germansk jernalder, vikingetid og middelalder. Den stratigrafiske analyse og udredning er meget udfordrende og bliver ikke nemmere af, at det udgravede areal kun udgør en beskeden del af det intensivt bebyggede område.

Sammenholdt med museets tidligere udgravninger i adelbyer og kendskabet til bebyggelse fra luftfotos, synes tilsvarende anlægstætheder at kendetegne i 


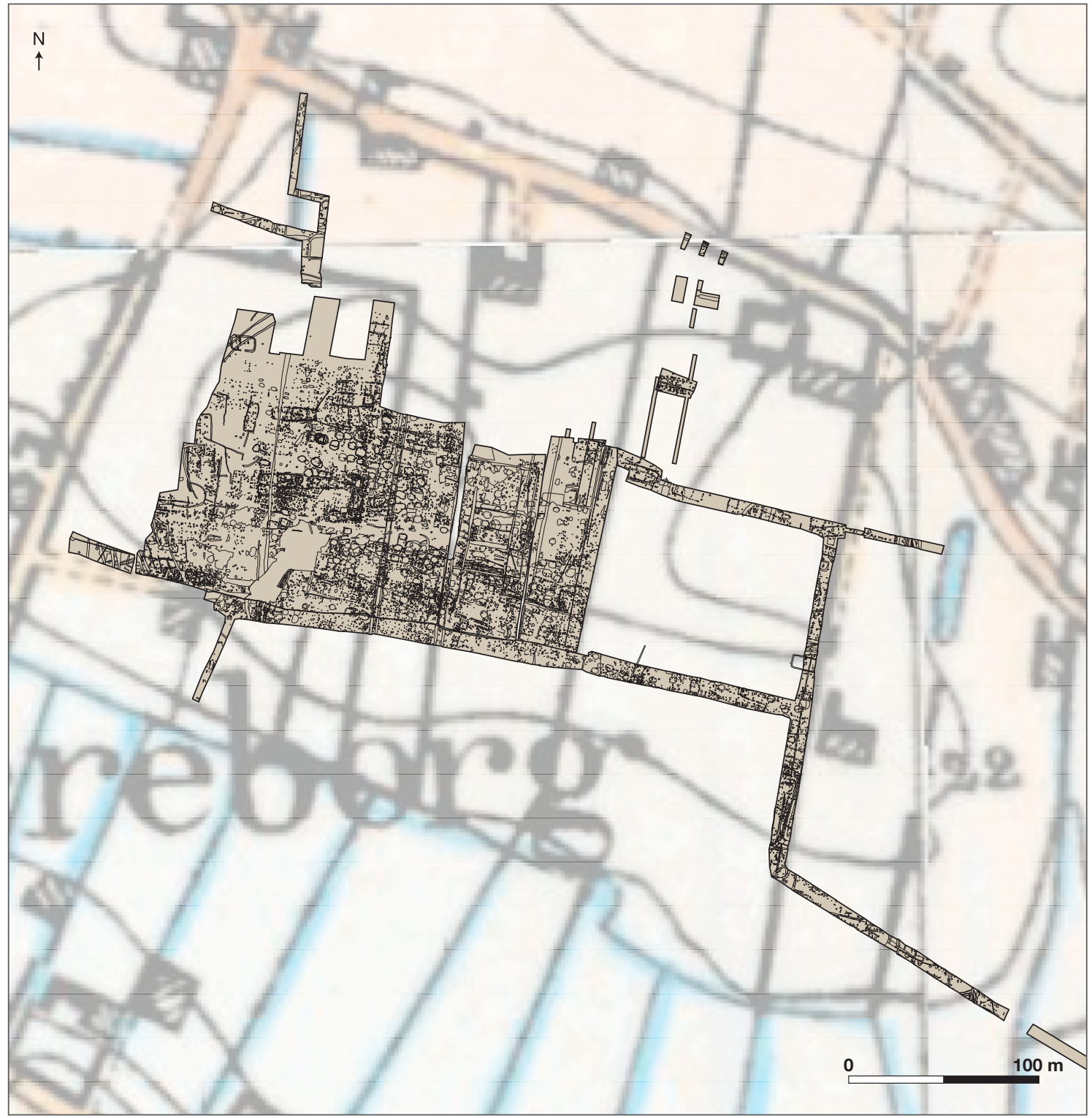

Fig. 13. I adelbyen Tjæreborg ud til marsken ligger bebyggelsen fra germansk jernalder, vikingetid og ældre middelalder koncentreret på en aflang forhøjning og udgør et meget kompliceret bebyggelsesbillede, hvis udredning og analyse kræver store ressourcer. Tilsvarende anlægstæthed kendes fra en række af de øvrige adelbyer i Sydvestjyske Museers ansvarsområde. - Efter original i Geodatastyrelsen med tilføjelser af forf.

In the main village of Tjæreborg, facing the coastal marshland, the settlement from the Germanic Iron Age and the Viking and Medieval periods is situated on a natural, oblong elevation. The very dense settlement over a long period of time has resulted in an extremely complex archaeological site. Similar situations are known beneath other main villages in the area covered by Museum of Southwest Jutland. 
hvert fald kystzonens adelbyer, som udgør langt mere komplekse og omfattende bebyggelser end locus classicus, Vorbasse, inde midt på den jyske hede. Og selvsagt kræver de en enorm udgravnings- og analyseindsats for at blive forstået i deres helhed og kompleksitet.

\section{Sædding}

I ejerlavet Sædding i Guldager sogn udgravede Esbjerg Museum fra 1974-1976 en velbevaret landsby fra vikingetiden under ledelse af Ingrid Stoumann. ${ }^{30}$ Ejerlavet er naturligt afgrænset på alle sider, og dets navn og størrelse taler mest for at klassificere det som en mindre adelby (fig. 14).

Det udgravede areal på blot 3,6 ha afslørede en landsby i forholdsvis få faser, hvor gårdene lå samlet omkring en åben plads, der opfattes som forten, landsbyens fællesareal. Ser man denne som centrum, kan landsbyen opfattes som næsten totaludgravet, men der er ikke foretaget en egentlig faseudredning, som kunne kvalificere denne tolkning, og det undrer også, at der mod sædvane tilsyneladende kun har været én vej ind og ud. Landsbyen har bestået af mindst fem samtidige gårdsanlæg, men spor efter andre kendes fra søgegrøfter syd for det udgravede areal, og området mod øst var ødelagt af en grusgrav.

Langt den overvejende del af Sædding-ejerlavets agerjord er i dag dækket af parcelhuskvarterer, som har opslugt de mange tidligere og senere faser af landsbyen. Men ældre løsfund og spredte iagttagelser viser, at der også lå en landsby i Sædding ejerlav både før og efter den udgravede fase fra vikingetiden.

Sædding er medtaget i denne eksempelrække som repræsentant for både en typisk vikingetidslandsby, men i lige så høj grad et billede på, hvor lidt vi i virkeligheden kan sige om bebyggelsesudviklingen, når udgravningerne er få og små. Nutidens udgravningsmetoder med forundersøgelser med efterfølgende udgravning af væsentlige bosættelseslevn leverer dette overblik, men analyse og publicering af de mange data forbliver en udfordring, som under normale omstændigheder ikke kan gennemføres inden for udgravningernes økonomi, og ofte er resultatet, at forskningsmæssigt afgørende lokaliteter aldrig kommer længere end til museernes arkiver.

\section{En model for jernalderens og vikingetidens bebyggelsesudvikling i Vestjylland}

Klimastudiernes påvisning af den senantikke lille istid følgende vulkanudbruddene i 536 og årene derefter præsenterer en stærk forklaringsmodel for en række fænomener, der har optaget forskningen omkring overgangen mellem 


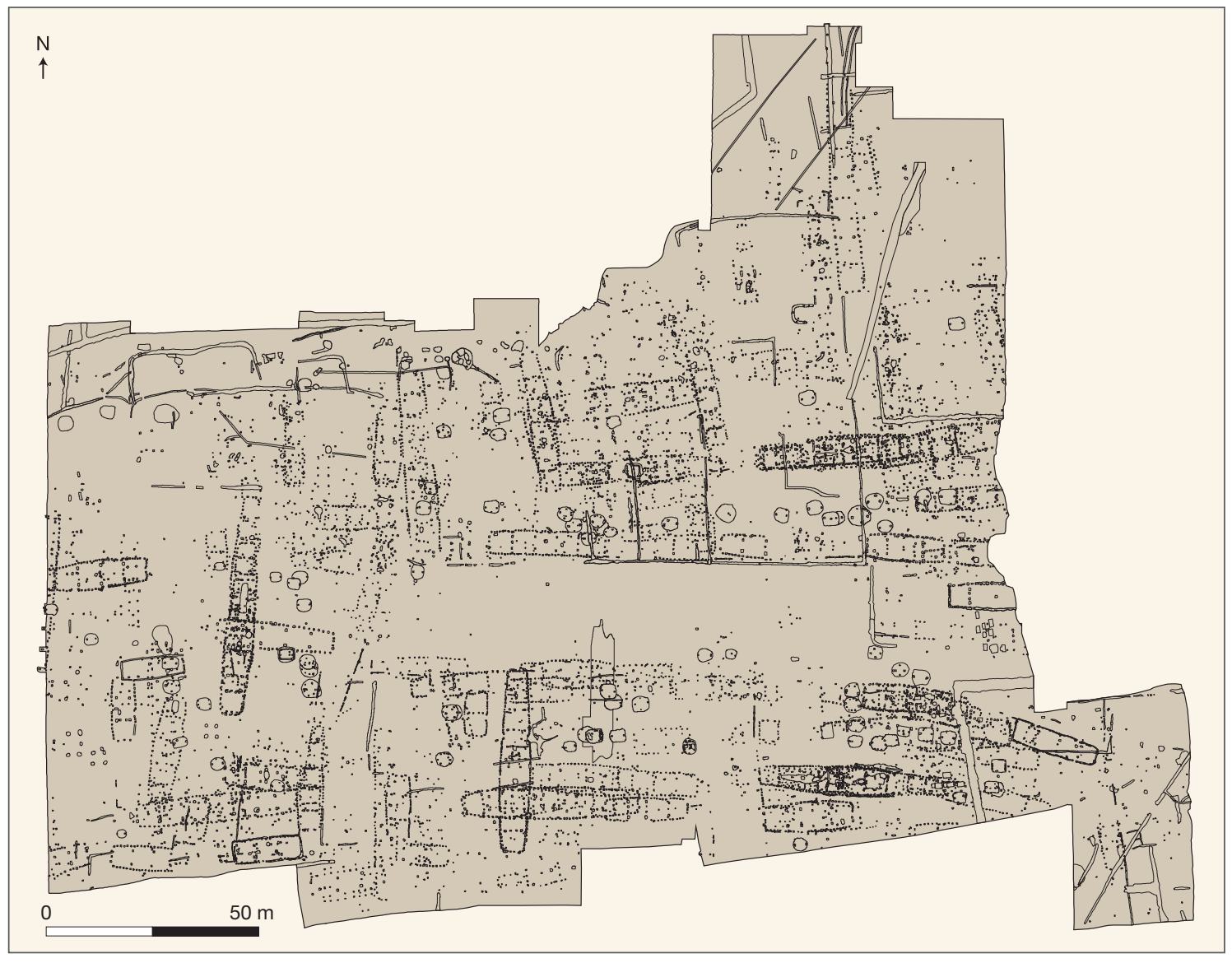

Fig. 14. Vikingetidslandsbyen i Sædding undersøgtes 1973-76 og består som i Vorbasse og andre steder af individuelle gårdsanlæg med et hovedhus og forskellige økonomibygninger beliggende på en afgrænset toft. De udgravede 4-6 gårde udgjorde formentlig kun den vestlige del af landsbyen og dækker i tid ca. tre faser, svarende til 100-150 år inden for tidsrummet 9.-10. århundrede - altså kun en episode i Sæddings lange bebyggelseshistorie. Udgravningen ESM 86, Kølhusvej.

The Viking Age village in Sædding was excavated between 1973 and 1976 and consists of individual farmsteads with a main building and various minor houses situated on a fenced-off croft. The four to six excavated farmsteads probably only represent the westernmost part of the village and cover roughly three phases, c. 100-150 years, within the 9 th and 10 th centuries.

ældre og yngre germansk jernalder. ${ }^{31}$ Her tænkes både på den iøjnefaldende guldofringshorisont i 6. århundrede, det markante og generelle fravær af grave og bebyggelse fra 7. århundrede, myten om Fimbulvinteren samt den ændring i både kunst, æstetik og arkitektur, som kendetegner periodeovergangen fra ældre til yngre germansk jernalder. ${ }^{32}$ 
Den udbredte brug af C14-dateringer i arkæologien vil i de kommende år tilføje udsagnstunge Big Data til denne problemstilling, men de indtil videre hundredvis af foreliggende dateringer alene fra Sydvestjyske Museer understøtter, at der var tale om en dyb samfundsmæssig krise, som resulterede i en meget betydelig befolkningsnedgang. Klimakrisen udgjorde den koldeste periode i de to første årtusinder, og ud fra fundenes fravær synes konsekvenserne at have været markant værre end pestens hærgen i 1350, som i sig selv var slem nok, da den menes at have slået omkring halvdelen af landets indbyggere ihjel. ${ }^{33}$

De ældre stednavnes overlevering antyder, at nogle mennesker trods alt overlevede og kunne videreføre en tradition, men det må regnes for en mulighed, at stednavnene i det yngre navnelag kan repræsentere nynavngivelser af tidligere bebyggede, men sidenhen forladte områder, hvilket, ikke overraskende, synes at gælde for mange torper. Et sandsynligt reaktionsmønster på krisen kunne være, at bebyggelsen trak sig tilbage til de bedste områder, adelbyerne, hvor de svage spor efter 7. århundrede er svære at påvise i sværmen af anlæg fra andre perioder.

Det vulkanske askeslør og de afledte konsekvenser kan forklare bebyggelsens forsvinden og langsomme genkomst fra anden halvdel af 6 . århundrede og frem til vikingetiden, men for de øvrige perioder er det generelle mønster, at alle de senere ejerlav er bebyggede, og at jernalderlandsbyernes størrelser, når de kan anslås, svarer nogenlunde til størrelsen på de landsbyer, som er afbildet på Original 1-kortet. Med sammenfaldet mellem Original 1-kortenes agerjord og den ældre bebyggelse in mente tyder det på, at hverken dyrkningssystemer eller gårdsantal gennemgik store forandringer.

Det kan skyldes, at dyrkningsenhederne hele vejen igennem de to første årtusinder var jævnstore familiebrug, som til sit udkomme krævede et areal af en vis størrelse, og at man allerede på et tidligt tidspunkt nåede frem til det omtrentlige antal gårde, et givet ejerlav kunne brødføde - og at dette tal ikke ændrede sig afgørende fra jernalderen og frem til tidlig moderne tid.

Den struktur, som landskabslovenes skelnen mellem adelbyer og torper udtrykker, genspejles i de udgravede jernalderlandsbyer og antyder, at også denne skelnen har dybe rødder. Der kan være tale om et selvgroet fænomen opstået i kraft af, at de bedst egnede landbrugsarealer tidligst er taget i brug og igennem længere tid har været kultiveret.

Diskussionen om socialstrukturen i middelalderens danske landsbyer har i det seneste halve århundrede været præget af forestillingen om, at der i samfundet fandtes en overklasse i form af stormænd, som udbyttede produktionsapparatet, altså udøvede magt over de andre, og det er foreslået, at denne samfundsgruppe kan spores tilbage til førromersk jernalder. ${ }^{34}$ 
Det udbredte og generelt velstående niveau i jernalderens landsbyer og grave passer imidlertid dårligt med billedet af en udpint bondestand, og hvis vi i stedet følger Chris Wickhams syn på Danmark i the Early Middle Ages, perioden 5001000, var det danske samfund i tidsrummet præget af en stor gruppe relativt frie bønder i et samfund med en svag eller ikke-tilstedeværende centralmagt, og dette må også gælde tiden forud. "At any level more signs of autonomy than control" ${ }^{35}$ Der fandtes en overklasse, som boede på stormandsgårde med sakrale funktioner, muligvis goder, men afgiftstrykket fra samfundets top mod de andre har været lavt i form af forskellige former for tribut, hvis der overhovedet var noget. Dette billede passer bedre med arkæologiens påvisning af jernalderlandsbyer bestående af jævnstore familiebrug $i$, hvad der synes at være hvert eneste ejerlav i Sydvestjylland.

Med til billedet hører, at i denne region er forskellene mellem de samtidige gårde i landsbyerne generelt små, og fundene fra både metaldetektering og grave viser lige så tydeligt, at luksusvarer i form af kvindernes smykker fandtes i hvert eneste ejerlav. Det tyder på, at samfundet - i hvert fald i Jylland - var præget af relativt - al frihed eller ufrihed er jo relativ - frie bønder samlet $i$ landsbyer bestående af jævnstore familiebrug. Der var forskelle gårdene imellem, men det var der også på gårdene omkring år 1800.

For jernalderens og vikingetidens vedkommende i Vestjylland er det fortsat vanskeligt at pege på håndfaste spor efter slavehold, hvorimod det synes oplagt, at man på de enkelte gårde har anvendt tyende i form af karle og piger, hvis behovet for arbejdskraft ikke kunne dækkes af familien selv.

Denne gennemgang af jernalderlandsbyerne og sammenligningen med det agrare landskab omkring år 1800 har afsløret en lang række strukturelle ligheder, som ikke synes at være tilfældige, men tyder på lang kontinuitet bagud i tid. Agerjordsarealerne og gårdsantallet synes i lange tidsrum at have været relativt konstant, men reguleret af klimatiske svingninger. Den påviste kontinuitet stiller spørgsmålstegn ved migration og konflikt som overordnet forklaringsmodel for jernalderens samfundsforandringer. I hvert fald i dette geografiske område.

Det agrare landskab i Vestjylland fremstår i undersøgelsen som et selvgroet system i et samfund af (relativt) frie bønder, hvor landskabets ydeevne og placeringen i forhold til trafik- og sejlruter synes at have været af større betydning end eventuelle magthaveres forsøg på regulering. Under dette generelle system har gårde løbende skiftet ejere, flyttet rundt, blevet delt og samlet, men normative forhold må have sikret, at gårdstallet ikke oversteg de enkelte ejerlavs bæreevne, og antagelig fungerede torperne som bufferzoner omkring adelbyerne. 
Hvis denne række af argumenter er retvisende, har det som konsekvens, at også middelalderens gårde, som er langt dårligere kendt end gårdene fra jernalderen og nyere tid, må antages at have fulgt det samme strukturelle mønster.

\section{Middelalderlige landsbyer og gårde omkring Ribe}

Udforskningen af middelalderens landbrugshistorie opstod, før arkæologiske udgravninger kunne bidrage til diskussionen og baserede sig i sin første tid på studiet af skriftlige kilder og bevarede gamle bøndergårde. ${ }^{36}$ Først fra senmiddelalderen foreligger et nogenlunde oplysende kildemateriale, som opridser billedet af en bondestand, hvor mange var fæstere og således underordnet jordejerne, typisk kongen, kirken eller adelen. Om disse forhold i samme omfang også var gældende i tiden forud, kan kilderne ikke oplyse om, og det har været diskuteret livligt, hvad der skal lægges i de ældste kilders latinske betegnelser for det agrare landskabs aktører: paganus $=$ bonde, colonus $=$ landbo, inqvilinus $=$ gårdsæde, villicus $=$ bryde.

Tilsvarende tvivl knytter sig til hele forståelsen af den ældre middelalders bondestand, herunder forholdet mellem selvejere og fæstebønder, den sociale stratifikation i gruppen og relationerne til andre grupper i samfundet, primært aristokratiet. ${ }^{37}$ Positionerne veksler imellem en opfattelse af, at udviklingen bevægede sig fra et system af mange "frie" bønder, som gradvis kom under kontrol af kirke, konge og adel, ${ }^{38}$ mens mere marxistisk inspirerede synspunkter i højere grad argumenterer for, at adelen, det senmiddelaldelige hovedgårdssystem og den medførende kontrol over bondestanden kan spores tilbage til jernalderens og vikingetidens centralpladser. ${ }^{39} \mathrm{Og}$ en række forhold tyder desuden på, at der var ikke ubetydelige regionale forskelle imellem Øst- og Vestdanmark. ${ }^{40}$

Axel Steensberg var en pionér inden for udgravninger af bøndergårde, men fra 1970'erne og frem blev forskningsfeltet strukturelt udfordret af, at fladeudgravningsteknikken, som blev formaliseret på Bopladsudvalgets udgravningskampagner (se ovenfor), i overvejende grad blev en undersøgelsesteknik, som anvendtes af forhistoriske arkæologer, og ikke alle prioriterede problemstillinger fra den historiske tid højt. Middelalderarkæologerne arbejdede i højere grad inde i byerne, og sådan var den generelle situation frem til det store boom i undersøgelser og ansættelser, som indførelsen af den nuværende museumslovs finansieringsprincipper medførte fra 2002.

Herefter er prioriteringen af den historiske landbebyggelse ændret, men udfordringen er blevet, at kun et fătal af de væsentlige udgravninger publiceres. En anden udfordring er, at dateringsgrundlaget for en række hustyper ikke er godt underbygget. Det har vist sig, at flere "middelalderlige" hustyper 
opførtes til op i 18. århundrede, og der er et stort behov for at etablere et bedre dateringsgrundlag ved anvendelse af C14-dateringer, eller når det er muligt, dendrokronologi..$^{41}$

Der er ikke bevaret skriftlige kilder, som i detaljer kan belyse de middelalderlige gårde og landsbyers udseende og socialstruktur, men de stærke kontinuitetstegn fra jernalder til nyere tid, jf. ovenfor, må betyde, at familiebrug samlet $\mathrm{i}$ landsbyer også i denne periode var det generelle billede. I Sydvestjyske Museers ansvarsområde er undersøgt en hel række middelalderlige gårde, men forståelsen af dem vanskeliggøres af, at tofteafgrænsningerne oftest ikke har efterladt spor i undergrunden, og de ligger også tit i sammenhæng med de eksisterende landsbyer, hvilket ikke hjælper heller. Men analogier til både tidligere og senere forhold kan belyse problemstillingen og afslører en række strukturelle forhold.

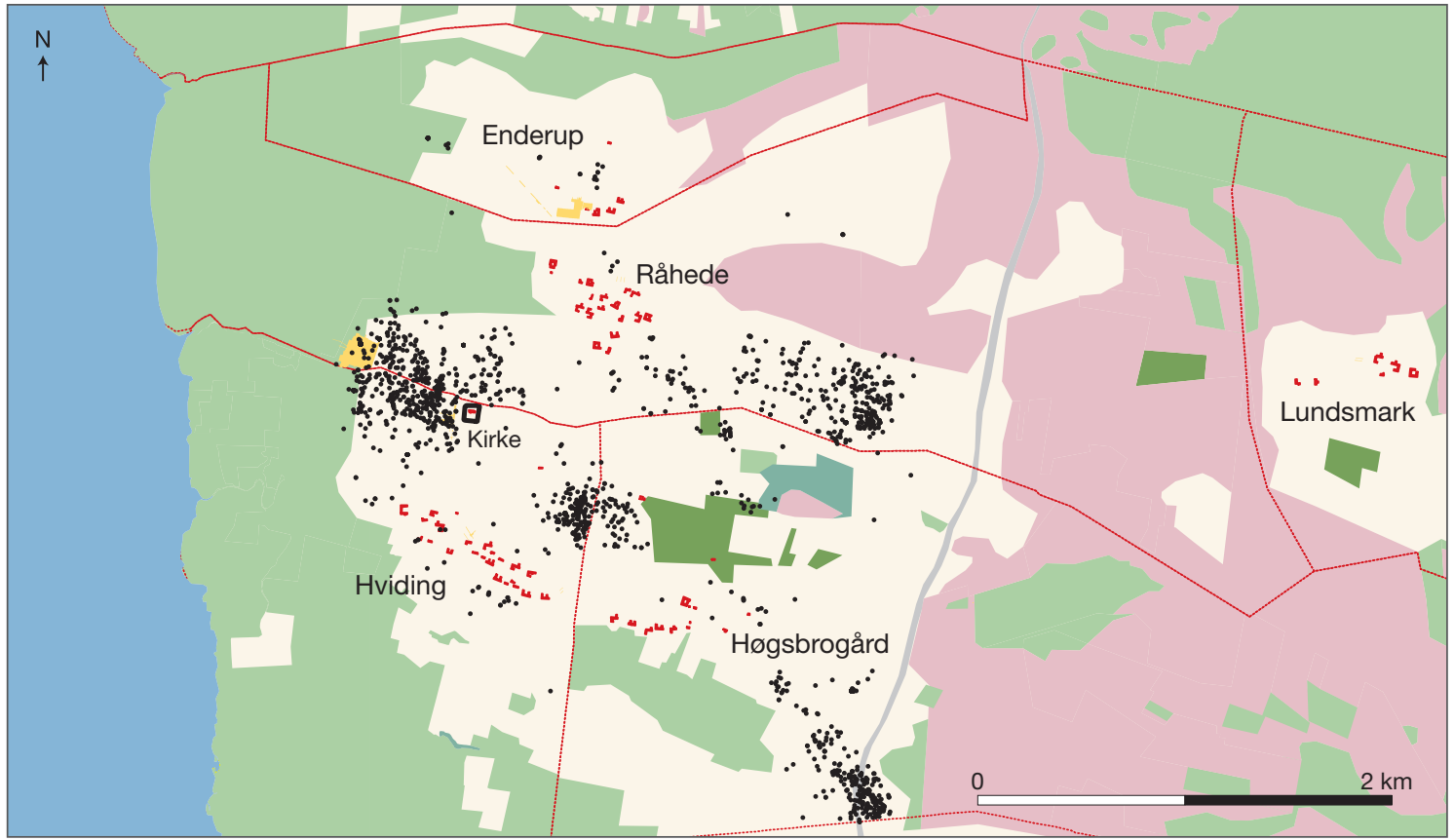

Fig. 15. Den vestlige del af Hviding sogn med landskabsudnyttelse, ejerlavsgrænser og bebyggelse omkring år 1800. De sorte prikker er detektorfund og med gult er udgravningsfelter markeret. Detektorfundene koncentrerer sig markant på den tidligere agerjord, og de hidtil foretagne udgravninger må formodes kun at være en dråbe i et hav af endnu ikke undersøgte fortidsminder. - Kort af forf.

The western part of Hviding parish showing land use, vills and settlement in c. 1800. Black dots are metal-detector finds, and excavations trenches are shown in yellow. The metal finds are clearly concentrated on the arable land, which hints at the existence of large archaeological sites underneath the plough soil. 
Som det også var tilfældet for jernalder og vikingetid, tegner der sig endnu ikke noget helt klart billede, og af samme årsag knytter sig de samme forhold til den følgende gennemgang af eksempler på forholdene i middelalderen.

\section{Gl. Hviding}

Vest for kirken i Gl. Hviding udgravede daværende leder af museet i Ribe, antikvar Stig Jensen, fra 1986-1994 en stor gård fra sen vikingetid og tidlig middelalder, som igennem sin levetid flyttede rundt inden for det udgravede

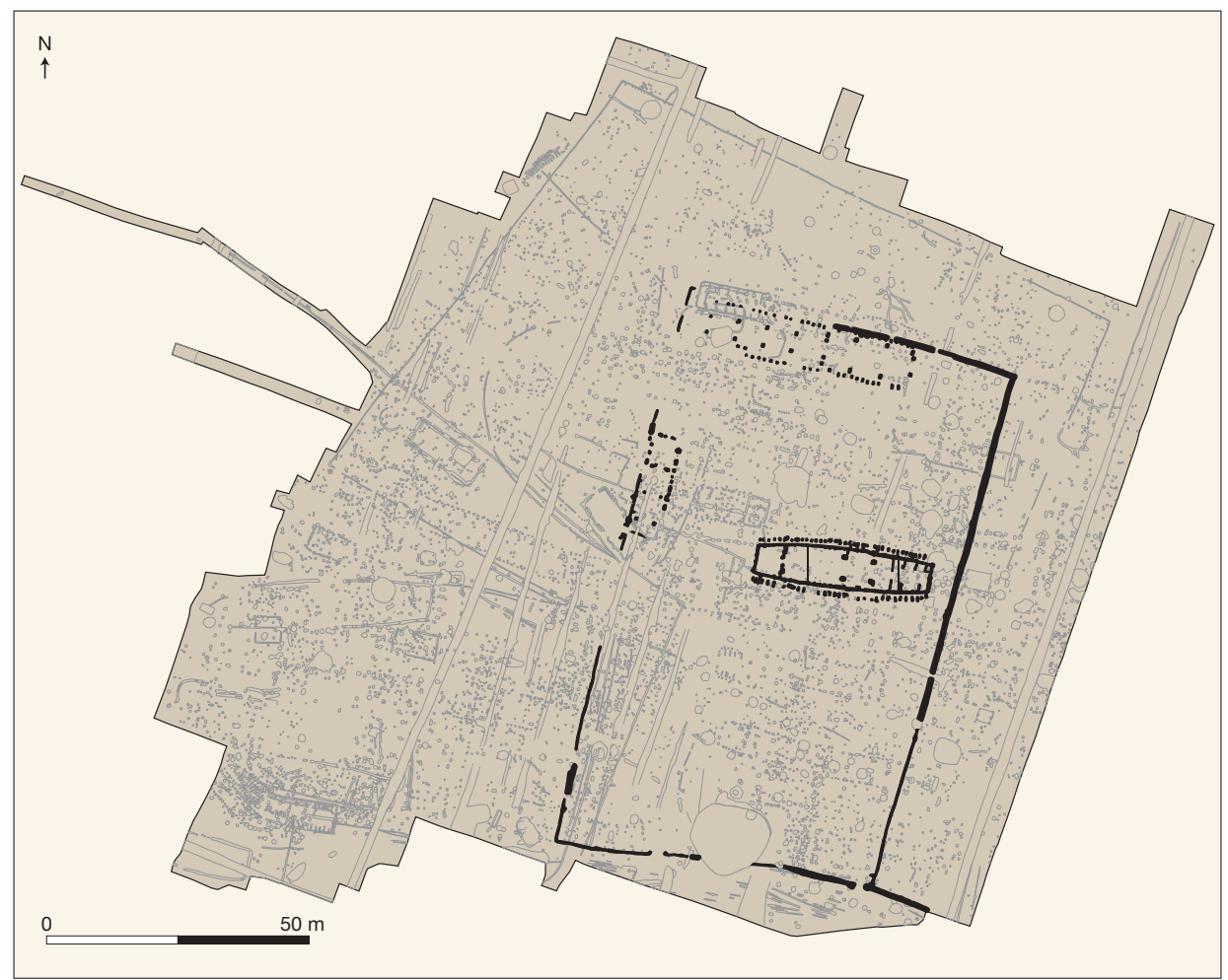

Fig. 16a. Udgravningen ASR 440, Gl. Hviding. Iagttagelse fra luften af det fine Trelleborghus, Hus I, på 34, 5 m var årsagen til udgravningen, som over de kommende år søgte at følge den store vandrende gård rundt til landskabet inden for rammerne af en meget begrænset økonomi. Her ses den ældste fase fra omkring år 1000, som desuden bestod af hegnshusene hus IIb, hus XXXVII og hus XLIII placeret langs toftehegnet, hegn A. Muligvis har den østre toftegrænse været reguleret, så hovedhuset oprindelig lå centralt på den plankeværksindhegnede toft. Udgravningen ASR 440, Gl. Hviding.

Excavation ASR 440, Gammel Hviding, phase I, c. AD 1000. Aerial observations led to the discovery of the Trelleborg-type house shown here. Excavations between 1986 and 1994, with limited funding, were able to trace this farmstead and its successors up until c. 1200. 


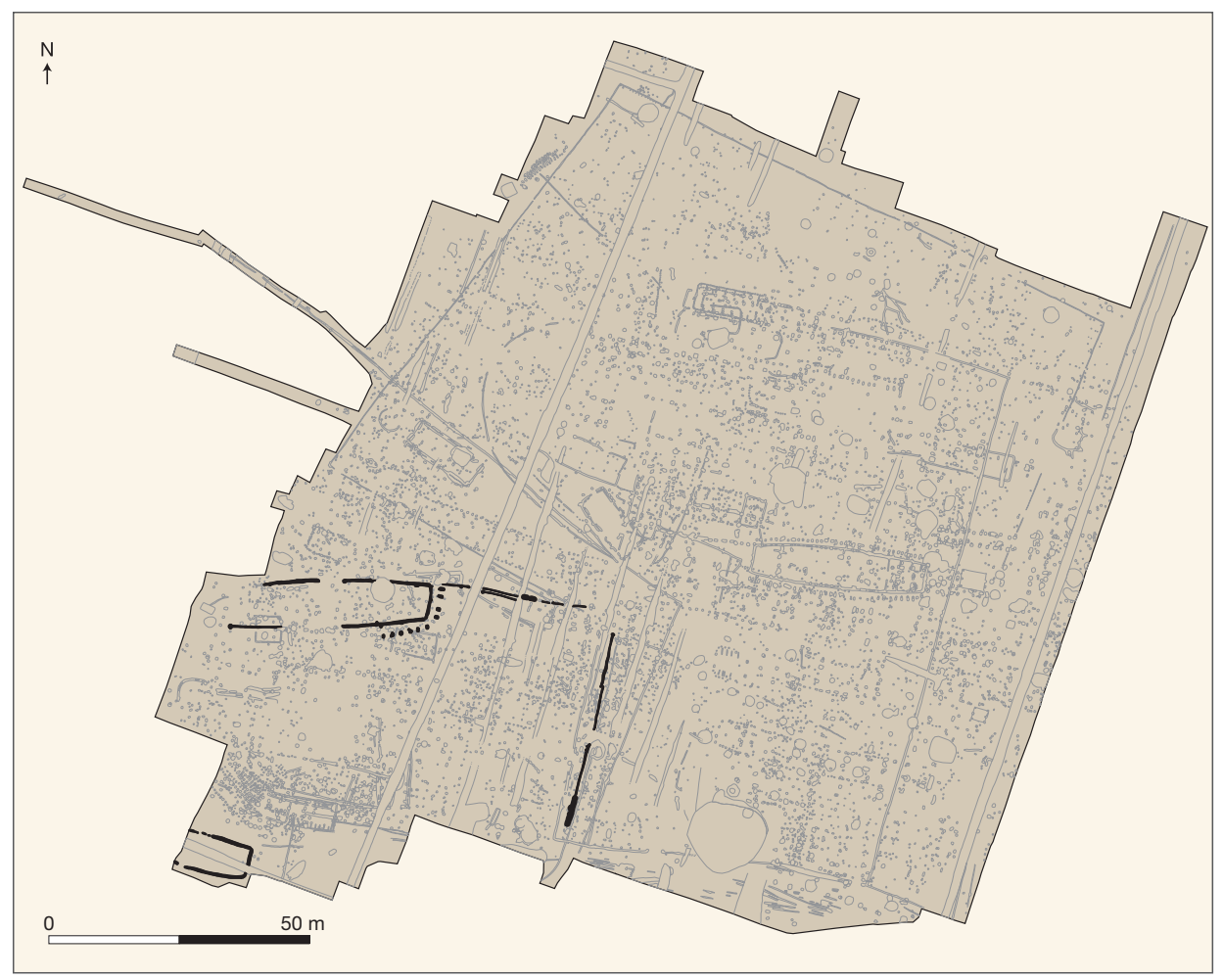

Fig. 16b. I den næste fase flyttede gården $100 \mathrm{~m}$ mod sydvest og bestod af et $40 \mathrm{~m}$ langt væggrøfthus, hus VIII, med formentlig sekundære støttestolper omkring husets sydøstre hjørne. Fasen, som hører hjemme omkring midten af 11. århundrede, er ikke komplet afdækket og muligvis var også væggrøfthuset, hus XV, en del af samme gård. Udgravningen ASR 440, Gl. Hviding.

In the following phase, from c. AD 1050, the farmstead moved $100 \mathrm{~m}$ towards the southwest and only parts of the associated croft have been uncovered. The main building was $40 \mathrm{~m}$ long.

område på ca. 2,5 ha (fig. 15). ${ }^{42} \mathrm{I}$ dag ligger den store tufstenskirke alene $\mathrm{i}$ landskabet. Frem til 1500-årene havde den en markant romansk totårnsfacade mod vest. ${ }^{43}$ Placeringen i forhold til sognets inddeling i ejerlav kunne tyde på, at der på et tidspunkt er sket en opsplitning med dannelse af ejerlavene Råhede og Høgsbro ved udskilning fra Hviding, og dette understøttes af, at bebyggelsesnavnene Råhede og Høgsbro først optræder i kilder fra senmiddelalderen.

Den udgravede gård ligger placeret ud for indsejlingen til Ribe. I ældre tid løb Ribe $\AA$ i Gammel Riber Dyb syd om Mandø, og de store bygninger har således været meget synlige for skibstrafikken. Udgravningen indeholdt også udstrakt bebyggelse fra jernalder og vikingetid, som i anlægstæthed svarer til forholdene i Tjæreborg, og antyder områdets tidligere rolle som adelby. 


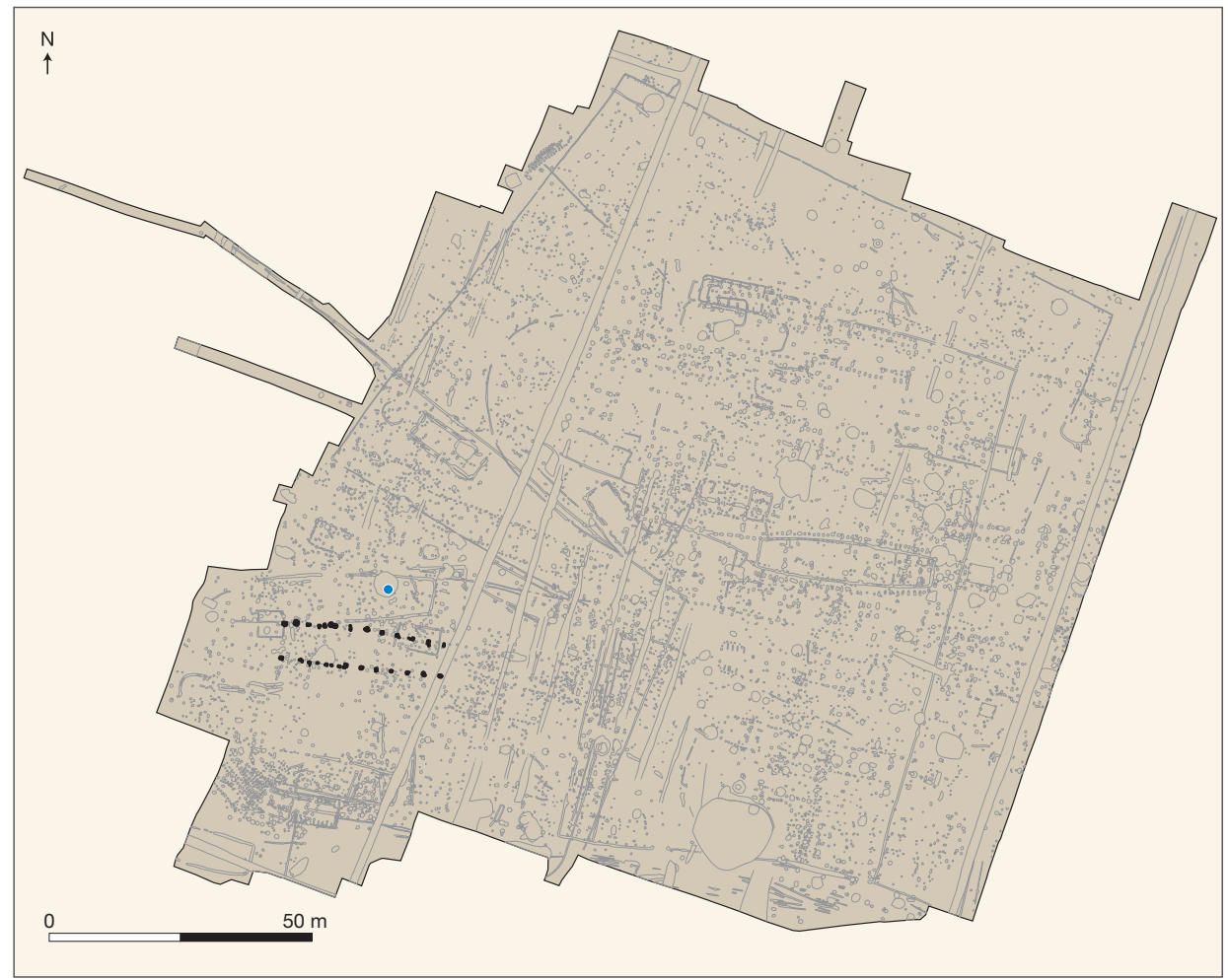

Fig. 16c. I den næste fase fra omkring 1100 bestod gården af hovedhuset, hus XII, på $32 \mathrm{~m}$ og muligvis også andre bygninger, men også her besværes tolkningen af, at toften næppe er fuldt afdækket. En brønd $9 \mathrm{~m}$ nord for huset, se fig. 17, skærer forgængerfasens hovedhus og er dendrodateret til 1101-11 (blå prik). Den må datere denne fase. Udgravningen ASR 440, Gl. Hviding.

In the following phase, from c. AD 1100, the main building measured $32 \mathrm{~m}$ in length and the date comes from an associated well which was dated by dendrochronology to 1101-11.

Gården fra sen vikingetid og tidlig middelalder synes at repræsentere en stor enestegård eller en gård uden direkte naboer, da den i sine forskellige faser kunne flytte uhindret rundt i området (fig. 16). Hvis denne antagelse er korrekt, er der altså tale om en enestegård med toftemarkering. Sekvensen af hovedbygninger udgøres først af et 38,5 m langt Trelleborghus, hus I, med stald i østenden fra omkring år 1000 efterfulgt af et $40 \mathrm{~m}$ langt og $10 \mathrm{~m}$ bredt væggrøfthus, hus VIII, som ikke havde afsat mange spor i undergrunden. Denne hustype var almindelig i første halvdel af 1000-årene. ${ }^{44}$ Herefter fulgte hus XII, en 32 m lang bygning med tagbærende stolper i væglinjen, som ud fra en nærliggende holkbrønd dendrodateret til 1101-11 antagelig er opført omkring dette tidspunkt (fig. 17). Alle disse hovedbygninger havde buede 


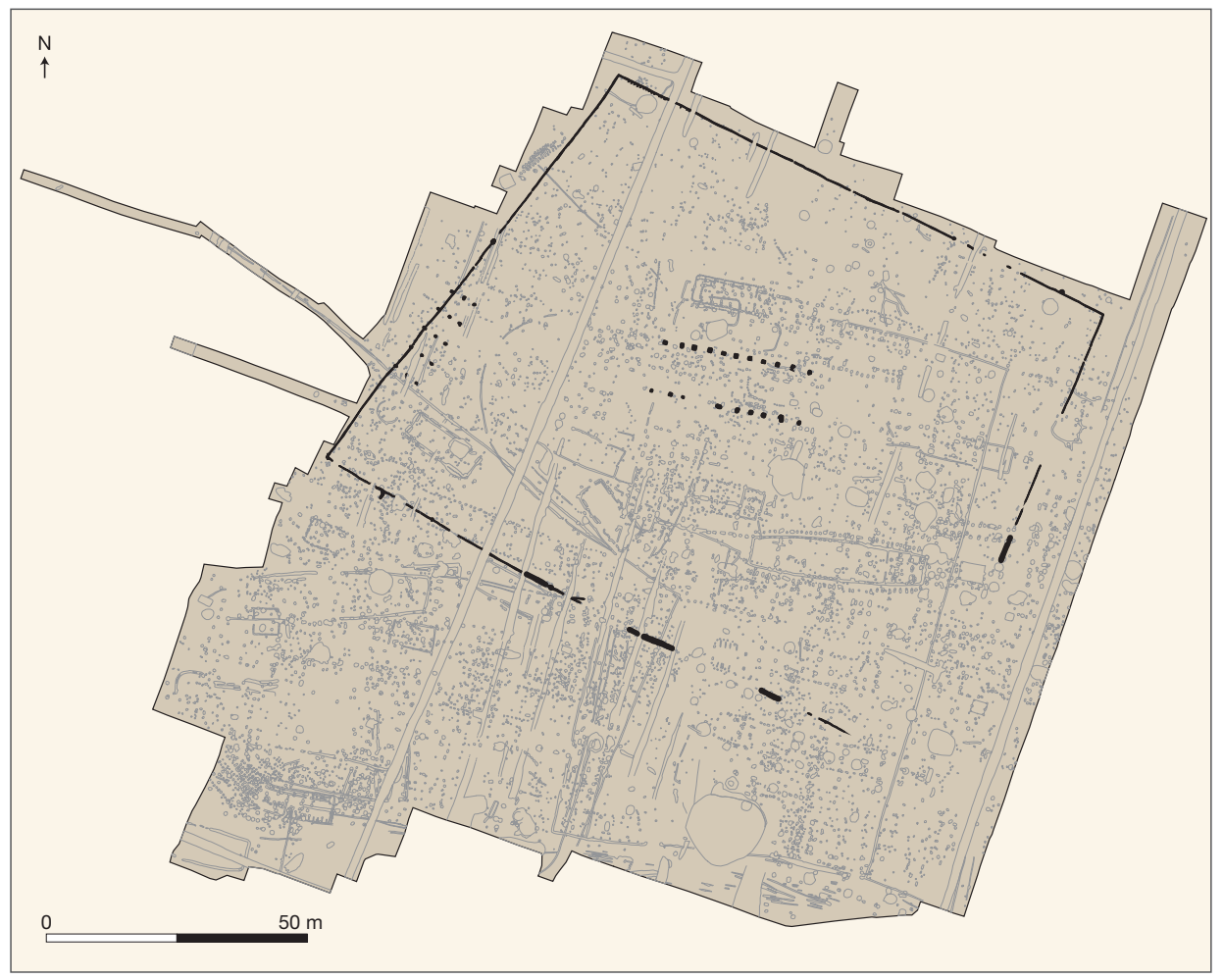

Fig. 16d. I følgende fase flyttede gården $85 \mathrm{~m}$ mod nordøst og bestod af et $10 \mathrm{~m}$ bredt og $34 \mathrm{~m}$ langt hovedhus, hus XXXIV, placereret centralt på en trapezformet, plankeværksindhegnet toft, hegn $\mathrm{B}$, der måler $130 \mathrm{~m}$ på længste led. Til gården hørte desuden et toskibet hegnshus, hus XXIV, formentlig en lade i sulekonstruktion. Udgravningen ASR 440, Gl. Hviding.

In the following phase, the farmstead moved $85 \mathrm{~m}$ towards the northeast; the main building was $34 \mathrm{~m}$ long and $10 \mathrm{~m}$ wide. This impressive building was placed centrally on a trapezoid, fenced croft.

langvægge, mens de tilhørende hegnshuse kunne have rette vægge. Den yngste fase udgøres af det kolossalt brede hus XXXIV på 34x10 m med rette vægge og tagbærende stolper i væglinjen beliggende centralt på en plankeværksindhegnet toft. Fra dette hus foreligger ikke selvstændigt daterende materiale, men ud fra sammenhængen opfattes det som afløser af hus XII og således næppe yngre end midten af 12. århundrede.

Hvem boede på den store gård? Fra mange års metaldetektering på markerne omkring udgravningsfeltet foreligger en større samling metalfund, som stort set ikke rummer ædelmetaller eller andre højaristokratiske indslag, og som heller ikke antyder hverken nævneværdig handel eller håndværk i gårdens levetid. Alligevel er sekvensen af bygninger blandt de største, vi kender fra 

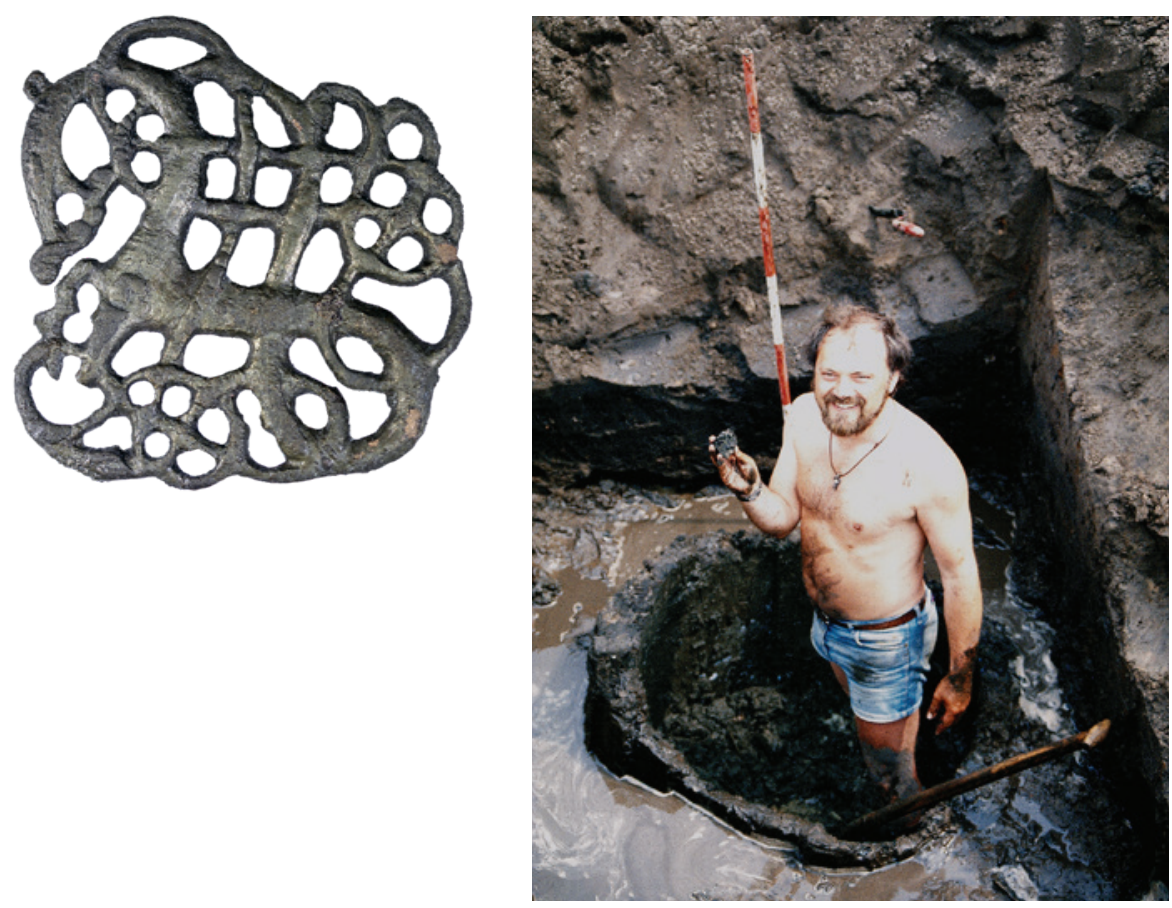

Fig. 17. Stig Jensen i færd med at udgrave brønd A763, en holk, dendrodateret til 1101-11 og samhørende med fase 3. Det smukke urnesspænde, ASR440x528, fandtes på bunden og må have tilhørt en af gårdens beboere. Det måler $4,8 \mathrm{~cm}$ på længste led.

Stig Jensen excavating well A763. The well shaft was made of a split and hollowed-out oak trunk dated by dendrochronology to 1101-11. The Urnes-style brooch was found at the bottom of the well and must have been worn by one of the local residents. It measures $4.8 \mathrm{~cm}$ in diameter.

Danmark. ${ }^{45}$ Det tyder mest på, at gårdmanden ikke var aristokrat, men i stedet en velstående fri bonde.

Oppe ved kirken, lige vest for kirkediget, er undersøgt en række mindre gårdstomter fra ældre middelalder, men deres relation til den store gård er ukendt.

Analysen af gården i Gl. Hviding rummer flere spekulative elementer og demonstrerer vanskelighederne ved at skrive bebyggelseshistorie på baggrund af kun en mindre udgravning, jf. Sædding ovenfor, selv når udgravningerne ikke er så små endda.

\section{Ribebispens gård i Lustrup}

I Lustrup, 11/2 km sydøst for Ribe, har museet fra 1998 indtil foreløbig 2014 undersøgt en stor enestegård fra 11- og 1200-årene. I dag indgår området i det ganske lille ejerlav Lustrupholm, som omkring 1800 kun rummede to 


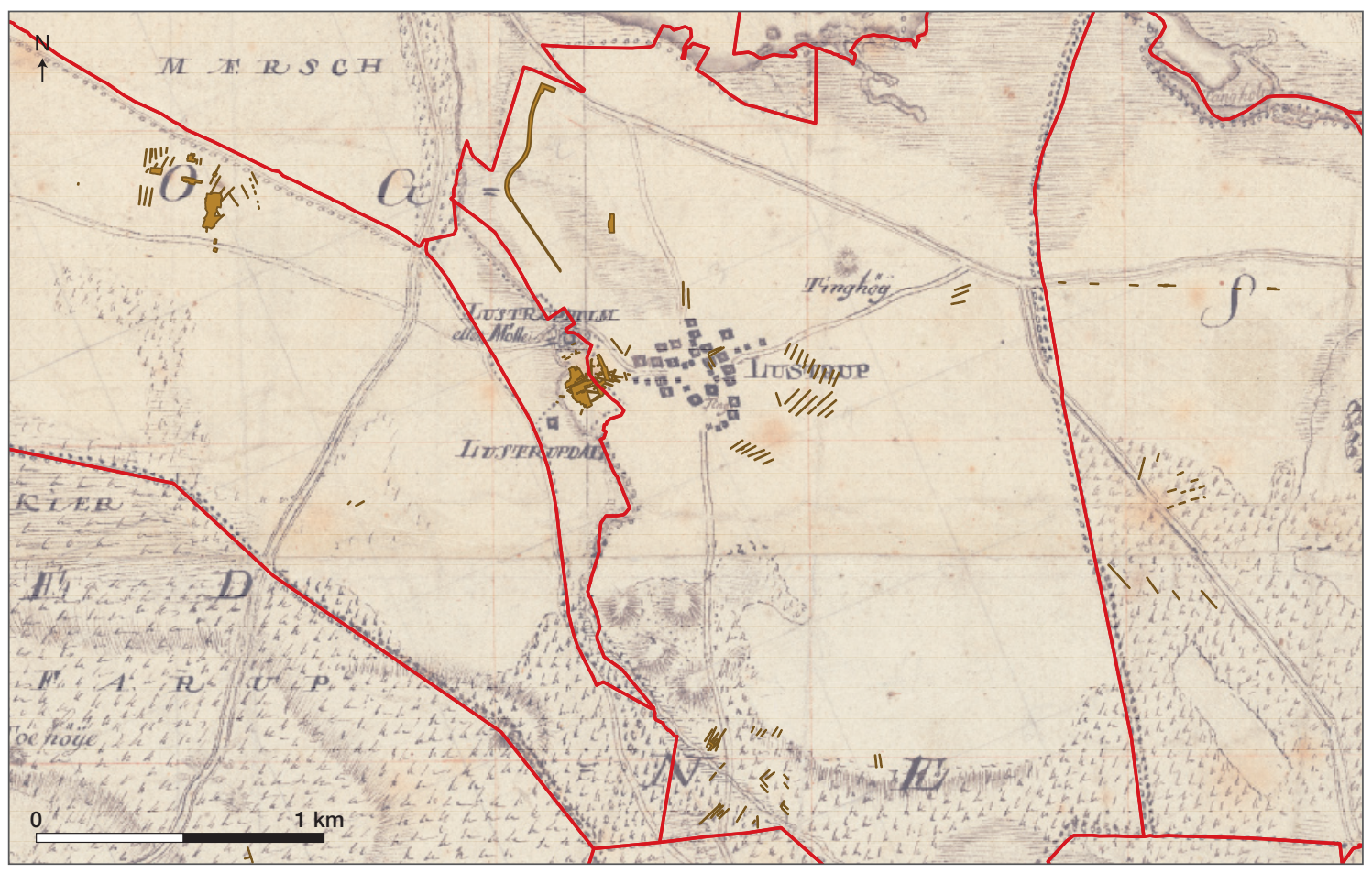

Fig. 18. Lustrupholm udgør i dag et lille ejerlav, som omkring 1800 rummede to gårde. Ejerlavsdiget mellem landsbyen Lustrup og Lustrupholm var yngre end hustomterne i bispens gård og repræsenterer således næppe de middelalderlige forhold. Kortbaggrunden er Videnskabernes Selskabs konceptkort fra 1794. - Efter original i Geodatastyrelsen med tilføjelser af forf.

The Lustrupholm vill consisted of two farmsteads in c. 1800. The dyke separating it from the Lustrup vill was later than the buildings belonging to the bishop's farm and does not reflect the Medieval situation. The background map is the Royal Society draft map from 1794.

gårde. Det synes tydeligvis at være udskilt fra ejerlavet Lustrup, men forløbet af ejerlavsskellet og de historiske oplysninger peger i retning af, at dette først skete lang tid efter den udgravede gårds levetid (fig. 18). Relationen imellem den store gård og landsbyen Lustrup kendes dermed ikke. I alt er ca. 1,2 ha udgravet. Ud over gården fra middelalderen fandtes også en gravplads fra bronzealderen og dele af en landsby fra yngre romersk-ældre germansk jernalder. ${ }^{46}$ Desuden er en forkullet bygkerne fra udgravningerne C14-dateret til 7.-8. århundrede, så trods torp-navnet er der også i Lustrup en lang forudgående bebyggelseshistorie.

Ribe Bispekrønike, som rummer fortegnelse over og kortfattede biografier om bispesædets indehavere frem til ca. 1230, fortæller, at bisp Elias, som sad 


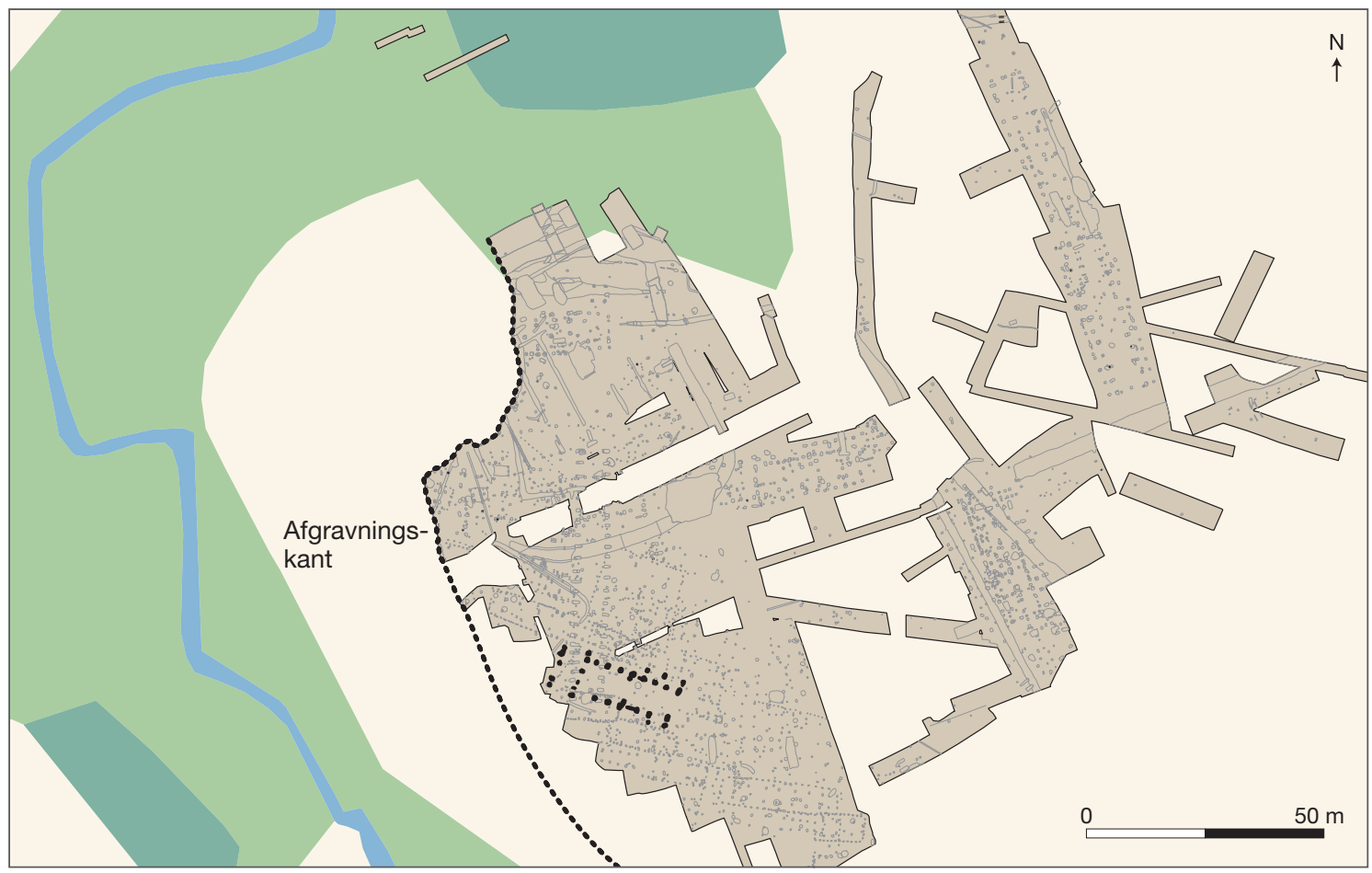

Fig. 19a. Den ældste middelalderlige fase i Lustrup udgøres af hus B, et $27 \mathrm{~m}$ langt hus med let buede langvægge, delvise udskud og en særlig indretning af vestenden. Husets plan er identisk med det nedenfor omtalte hus C fra Vilslev, og dateringen er formentlig begyndelsen af 12. århundrede. Udgravningerne ASR 1301, ASR 1700 og SJM 424, Lustrupholm.

The first phase at Lustrup was building B, a $27 \mathrm{~m}$ longhouse from the early 12 th century.

på bispestolen fra 1142-62, befæstede de biskoppelige gårde, og i 1233 og 1258 ved vi, at Ribebisperne Gunner og Esger ejede en særlig gård i Lustrup, som bønder langvejs fra var forpligtede til at levere deres naturalieafgifter til. ${ }^{47} \mathrm{I}$ Lustrup er rent faktisk udgravet en befæstet gård fra 12. århundrede efterfulgt af meget store, senere faser, og dermed er vi i et af de sjældne tilfælde, hvor vi både kan identificere og datere en udgravet middelaldergård (fig. 19).

Den ældste fase udgøres formentlig af Hus B, et $27 \mathrm{~m}$ langt hus med buede langvægge, udskud og den særlige indretning af den vestlige ende, som i nogle tilfælde er foreslået som portrum, ${ }^{48}$ men da vognskjul også har indgået i både xldre og yngre gårde uden at komme til udtryk i stolpernes placering i jorden, er denne tolkning ikke uden forbehold. Ud fra sin typologi er huset formentlig opført i første halvdel af 12. århundrede. I samme periode voksede 


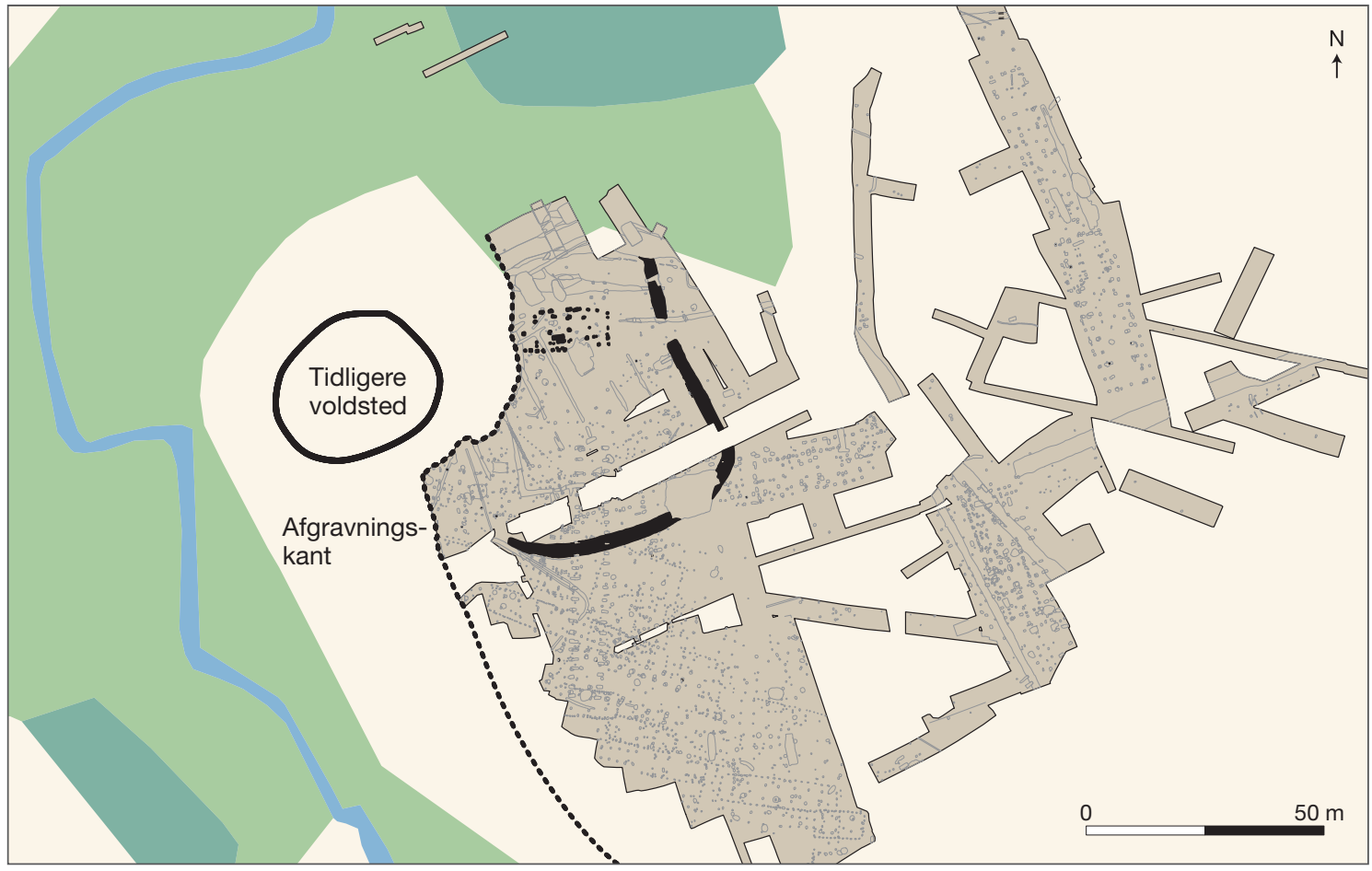

Fig. 19b. Den følgende fase udgøres af Hus A, et desværre meget ødelagt hus med buede langvægge, hvis bredde har været imponerende $9 \mathrm{~m}$ og en mulig årsag til, at huset senere fik indsat midtsuler. Gården er omgivet af den buede grøft 1, og til anlægget må også have hørt det mindre voldsted, som omtales på stedet i 1800-årene. Udgravningerne ASR 1301, ASR 1700 og SJM 424, Lustrupholm.

The following phase consists of building A, which was only partially preserved but evidently $9 \mathrm{~m}$ wide. A ditch or small moat surrounded the building, and in the 19th century a small motte was still preserved further west.

det afgiftssystem frem, som gården spillede en rolle i, hvilket styrker opfattelsen af denne som grundlæggergården.

Næste fase udgøres af en stor hovedbygning, hus A, som er omgivet af en ca. $3 \mathrm{~m}$ bred og omkring $1 \mathrm{~m}$ dyb voldgrav med en åbning mod øst. Desværre er denne fase delvist ødelagt af sandgravning i 20. århundrede, men i 19. århundrede omtalte Ribehistorikeren J. Kinch et voldsted ved Lustrupholm, hvis placering kan rekonstrueres ud fra ældre kort. ${ }^{49}$ Dermed fremstår billedet af en befæstet gård bestående af et stort hovedhus omgivet af en voldgrav samt et tilhørende mindre voldsted, hvis nærmere udseende desværre ikke kendes. Det må være en af disse gårde, der hentydes til i bispekrøniken, og dermed kan fasen dateres til Elias' embedsperiode, årtierne omkring 1150. 


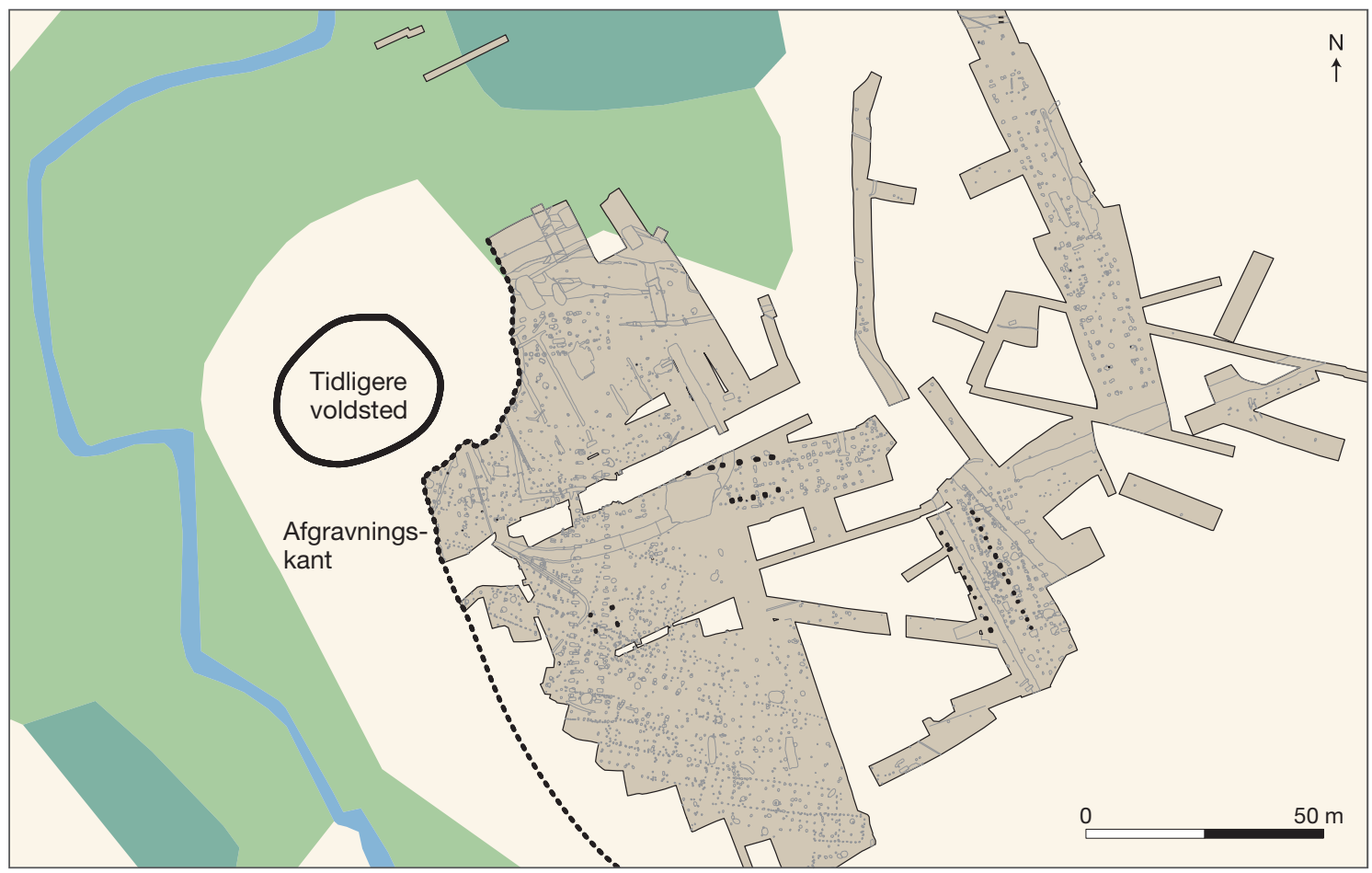

Fig. 19c. I anden halvdel af 12. århundrede opførtes næste fase, et tofløjet anlæg bestående af det over $8 \mathrm{~m}$ brede hus C og sydøst herfor det knap $8 \mathrm{~m}$ brede hus D samt muligvis også firstolpeanlægget hus E. Udgravningerne ASR 1301, ASR 1700 og SJM 424, Lustrupholm.

In the second half of the 12th century the farmstead was relocated and then consisted of two $8 \mathrm{~m}$ wide buildings.

I næste fase kom gården til at bestå af to store bygninger med rette vægge, et tofløjet anlæg, som må tilhøre anden halvdel af 12. århundrede. Denne struktur opretholdes, da gården omkring 1200 nybyggedes med tilføjelse af et teglstensbygget tårn på $8 \times 8 \mathrm{~m}$, i hvis bagmure også indgik importeret tuf. Et træbygget trappetån viser, at der over en halvkælder har været mindst to stokværk, og møntfund fra 1200-årenes begyndelse indlejret i forskellige gulvfaser leverer dateringsgrundlaget.

Det allerede omfattende kompleks suppleredes senest i 1200-årenes første halvdel med meget store økonomibygninger på 54x6 og 34x10 m, og det er i samme tidsrum, at kilderne fra 1233 og 1258 fortæller, at afgiftspligtige bønder for egen regning skulle transportere deres produkter til bispens gård i Lustrup. Fundmaterialet tyder på, at gården nedlagdes inden 1300. 


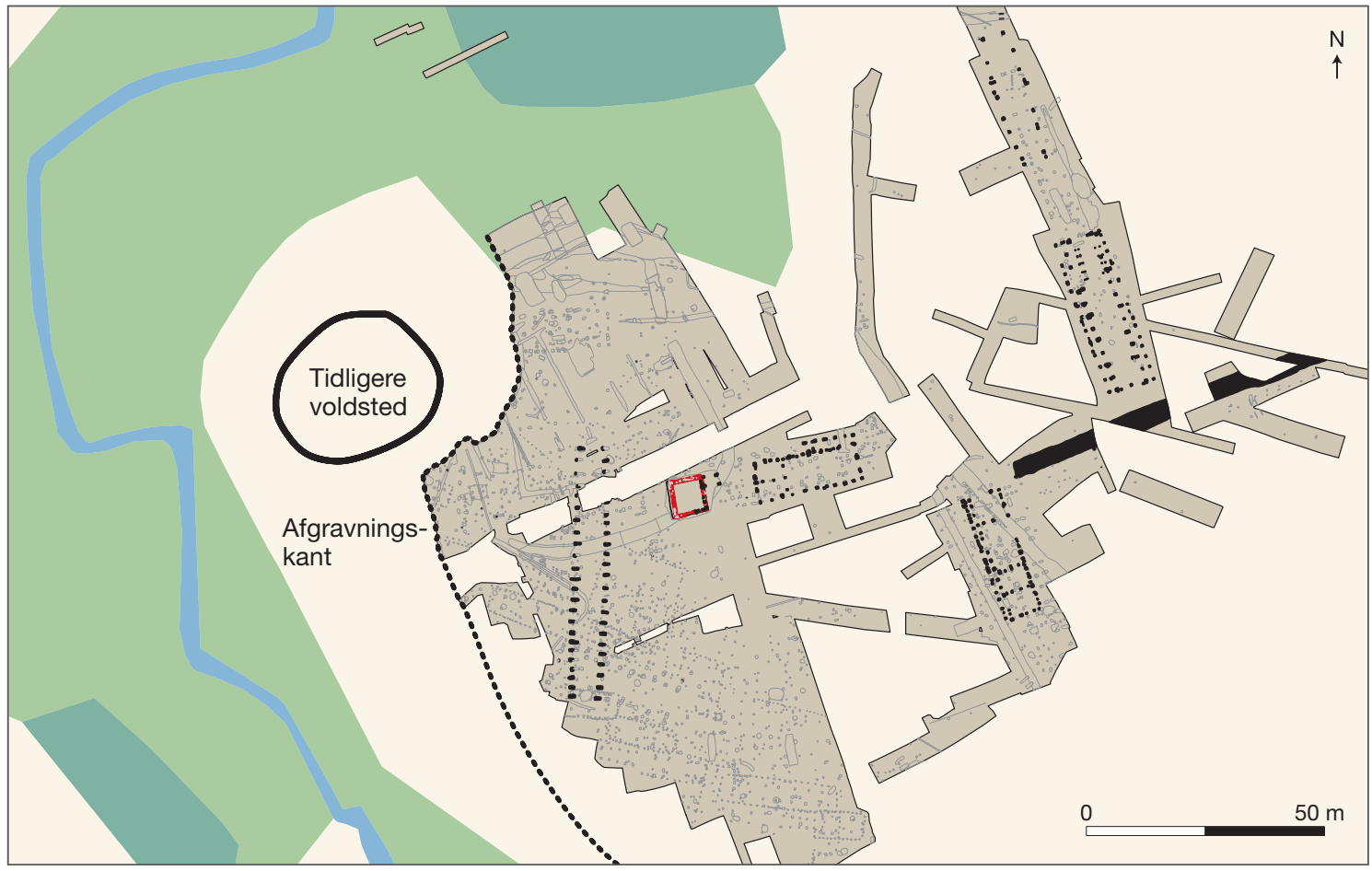

Fig. 19d. Frem til 1200-årenes midte var byggeaktiviteten på gården i Lustrup enorm. De to bygninger fra den foregående fase erstattedes af nye på næsten samme placering, hus F og G, og til anlægget føjedes et teglbygget tårn, hus H, på 8x8 m i minimum to stokværk over en høj kælder. Til det i forvejen store anlæg føjedes en $54 \mathrm{~m}$ lang ladebygning mod vest, hus $\mathrm{K}$, og en treskibet stald og/eller lade mod øst, hus L og nord for dette endnu en bygning, hus M. Funktionen af den snorlige grøft 4, hvis sider var sikret med opstablede græstørv, er ukendt. Både bygningernes størrelse og antal adskiller sig meget markant fra områdets øvrige kendte gårde. Udgravningerne ASR 1301, ASR 1700 og SJM 424, Lustrupholm.

Until the mid-13th century, a great deal of building activity took place at Lustrup. An 8x 8 $\mathrm{m}$ brick tower with a wooden staircase was erected in c. 1200 and large barns and stables were added to this impressive complex.

Både bygningernes størrelse, antal og befæstningen viser klart, at gården i Lustrup er helt ekstraordinær og må betegnes som en specialiseret storgård. Modsat en hovedgård synes driften ikke at have været baseret på et stort jordtilliggende, men snarere at have fungeret som centrallager for de landbrugsprodukter, bispen kunne afhænde til de mange købmænd, som i samtiden besøgte Ribe. At gården måske også kan have spillet en rolle i den omfattende eksport af heste fra Ribe, som er omtalt i Kong Valdemars Jordebog, er en mulighed, der heller ikke skal udelukkes. Denne helt særlige rolle i den agrare økonomi kan også forklare, hvorfor gården i Lustrup fortsat står ret alene blandt de mange udgravede middelalderlige gårde i Danmark. 


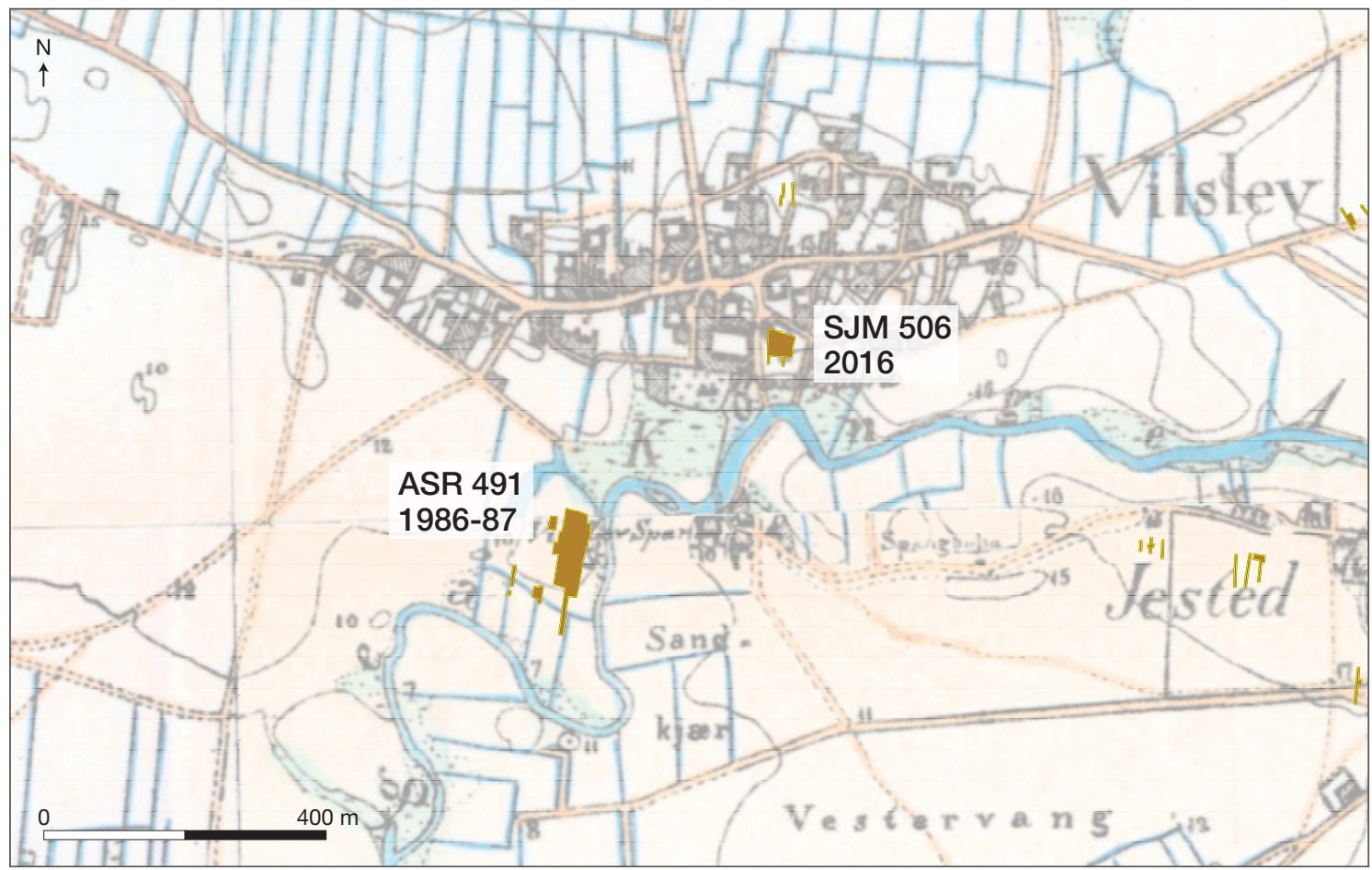

Fig. 20. Stig Jensens udgravning i 1986-87, ASR 491, var placeret sydvest for landsbyen. I 2016 udgravedes en grund lige øst for præstegården i den eksisterende landsby, SJM 506, som ligger på en aflang, naturlig banke. Også under landsbyen fandtes mange faser af gårde rækkende tilbage til ældre middelalder og herunder bebyggelse fra jernalderen. - Efter original i Geodatastyrelsen med tilføjelser af forf.

Stig Jensen's excavation in 1986-87, ASR 491, took place southwest of the village of Vilslev. In 2016, a plot in the centre of the village was excavated, SJM 506, exposing multi-phased settlement extending back to the 12th century. Evidence of Iron Age settlement was also found.

Fig. 21. Udgravningen i Vilslev afdækkede en hel serie fint bevarede, velvoksne hustomter, som formentlig udgør tre samtidige gårdsanlæg fra 12. århundrede i flere faser samt en række andre hustomter, hvis datering og sammenhæng med de øvrige huse er mere usikker. Også store gårde kunne altså ligge på små tofter. Det fine urnesspænde, ASR491x21, fandtes $\mathrm{i}$ et stolpehul i nordvæggen på hus A og er identisk med spændet fundet i brønden i Hviding (fig. 17). Udgravningen ASR 491, Vilslev.

The 1986-87 excavation exposed a series of well-preserved buildings, probably three contemporary farmsteads from the 12 th century in several phases. The Urnes-style brooch, ASR491x21, was found in a posthole in the north wall of building A. It is identical to the brooch found at Hviding (cf. fig. 17). 


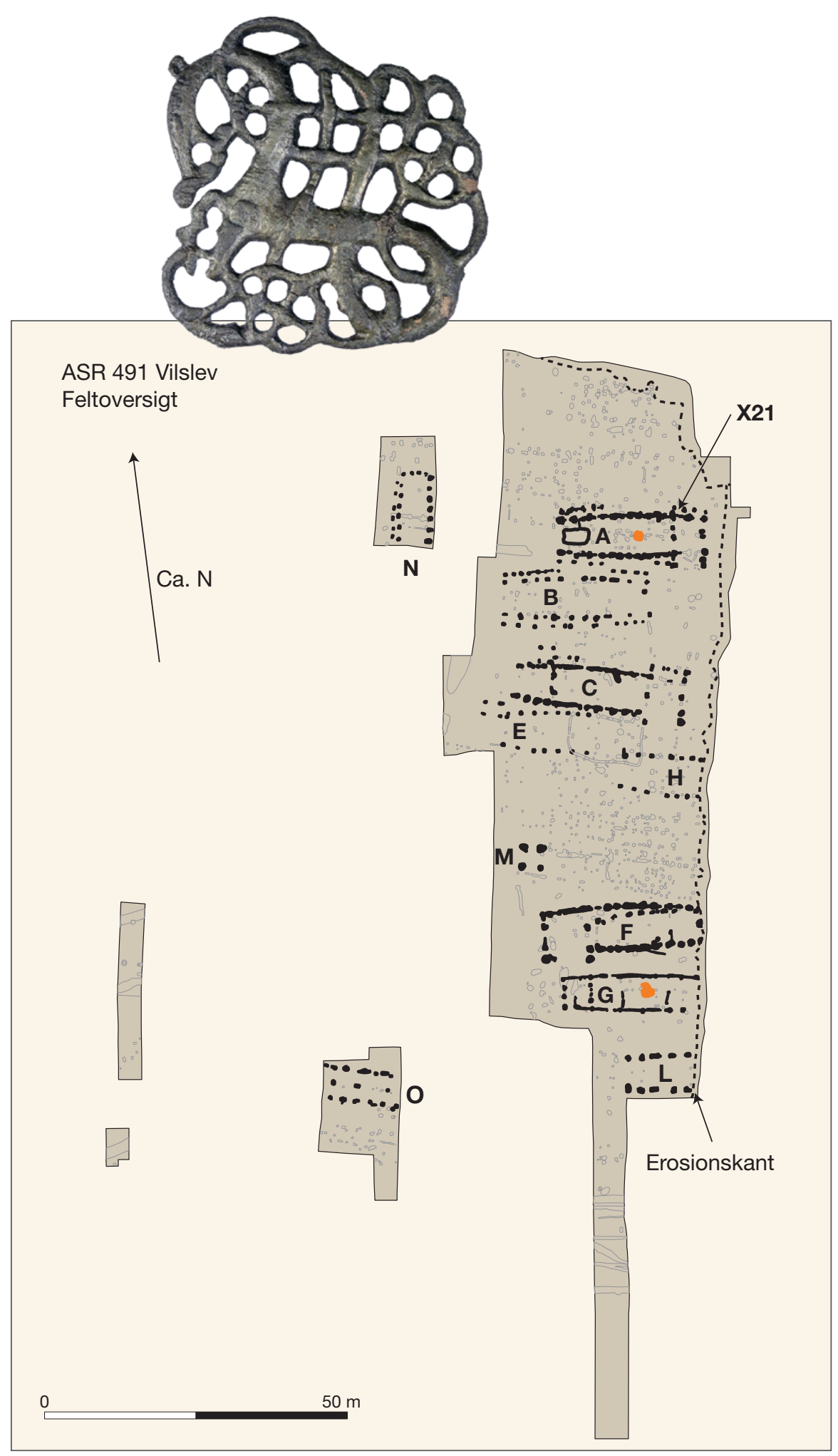




\section{Vilslev}

I det omfattende marskejerlav Vilslev i sognet af samme navn udgravede Stig Jensen i 1986-87 et mindre felt, som indeholdt en række velbevarede hustomter fra sen vikingetid og tidlig middelalder (fig. 20). Lokaliteten var påvist som afgrødespor iagttaget fra luften, og det samlede udgravede areal er kun lidt over 0,5 ha. ${ }^{50}$ Hustomterne er publiceret som værende samtidige, men for en nutidig betragtning er der næppe tvivl om, at de snarere udgør forskellige faser af to til tre samtidige gårdsanlæg (fig. 21). Der er tale om store og velbyggede huse på op til 27 meters længde, og hus C har en nøjagtig parallel i Hus B fra Lustrupholm (fig. 19a), som tyder på, at husenes plan må være udstukket efter en form for skabelon. I et stolpehul i nordvæggen af Hus A fandtes et stort Urnesspænde, næsten helt identisk med spændet fra Gl. Hviding, som daterer i hvert fald dette hus til begyndelsen af 12. århundrede.

Mod øst er udgravningen afsluttet af en erosionskant skabt af Kongeåen, og det er vanskeligt at vurdere, hvor meget åen kan have skyllet bort siden ældre middelalder. Andre afgrødespor er med til at vise, at der befinder sig andre hustomter uden for udgravningsfeltet, så frem for at opfatte de udgravede hustomter som en enhed, er der snarere tale om et lille udsnit af en langt større og dårligere kendt helhed.

Øst for den fine sognekirke i Vilslev foretog museet i 2016 udgravning på en byggegrund i den eksisterende landsby. Her fandtes en meget stor mængde anlæg fra nyere tid og bagud i tid til ældre middelalder, som for de ældste hustomters vedkommende kan være samtidige med gårdene udgravet 198687. I betragtning af landsbyen Vilslevs betydelige omfang og store gårdstal i nyere tid synes det mest sandsynligt, at det også har været en stor landsby med mange gårde i ældre middelalder.

Som et vigtigt resultat viser Stig Jensens udgravning, at også store hovedhuse kunne ligge ganske tæt på hinanden, og at der således ikke nødvendigvis er en 1:1 sammenhæng mellem store tofter og store hovedhuse.

\section{Hunderup}

I ejerlavet Hunderup i sognet af samme navn udgravede museet i 2002 et udsnit af den historiske landsby forud for udstykning af parcelhusgrunde (fig. 22). Feltet lå knap $200 \mathrm{~m}$ vest for sognekirken. $300 \mathrm{~m}$ mod sydvest er udgravet en gravplads fra yngre vikingetid, anlagt ved en megalit fra tragtbægerkulturen med sekundærbegravelser fra ældre jernalder. ${ }^{51}$ Fra andre småudgravninger i ejerlavet kendes bebyggelse fra andre perioder af forhistorien. Trods torpnavnet er der altså også i Hunderup en lang bebyggelseshistorie bagud i tid. 


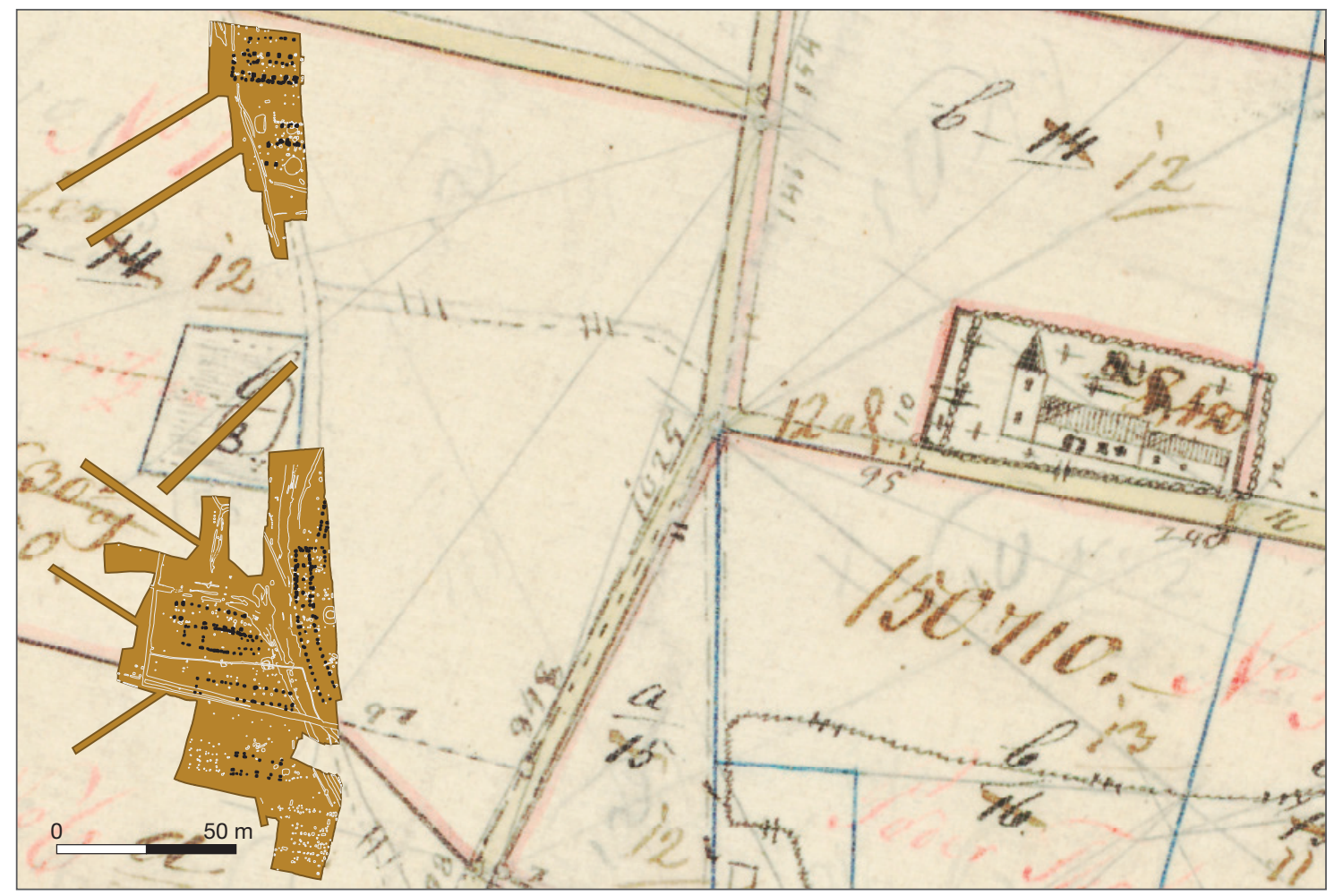

Fig. 22. I 2002 foretog museet en udgravning i Hunderup forud for udstykning og påviste en serie hustomter beliggende ud til en gennemgående vej. Den var i brug frem til omkring 1800 og udtrykker således en lang kontinuitet i landsbyens overordnede struktur. Kortbaggrunden er Original 1-matrikelkortet dateret 1820, og på den tid lå landsbyens gårde lidt længere mod syd. Udgravningen ASR 1442, Møllevænget. - Efter original i Geodatastyrelsen med tilføjelser af forf.

In 2002, an excavation was carried out in Hunderup, ASR 1442 Møllevænget. A series of buildings were found facing a road. The road remained in use until c. 1800, and it documents the long continuity of the structural layout of the village. The background map is the first cadastral map of 1820 .

Udgravningen påviste et større antal hustomter, som lå på begge sider af et let slynget vejforløb (fig. 23). Der var hustomter med buede langvægge, som dateres til ældre middelalder, to brønde, der blev dendrokronologisk dateret til henholdsvis 1170 'erne og 1296 samt andre retvæggede hustomter af middelalderlig type.

Først efter udgravningen fik museet adgang til det ældste matrikelkort over landsbyen, en "Copie" fra 1820, og her viste det sig overraskende, at den middelalderlige landsbygade var optegnet på kortet som et sløjfet vejforløb. Det må betyde, at vejforløbet har været eksisterende på enten et forlæg for kortet eller er sløjfet i kortets brugstid. 


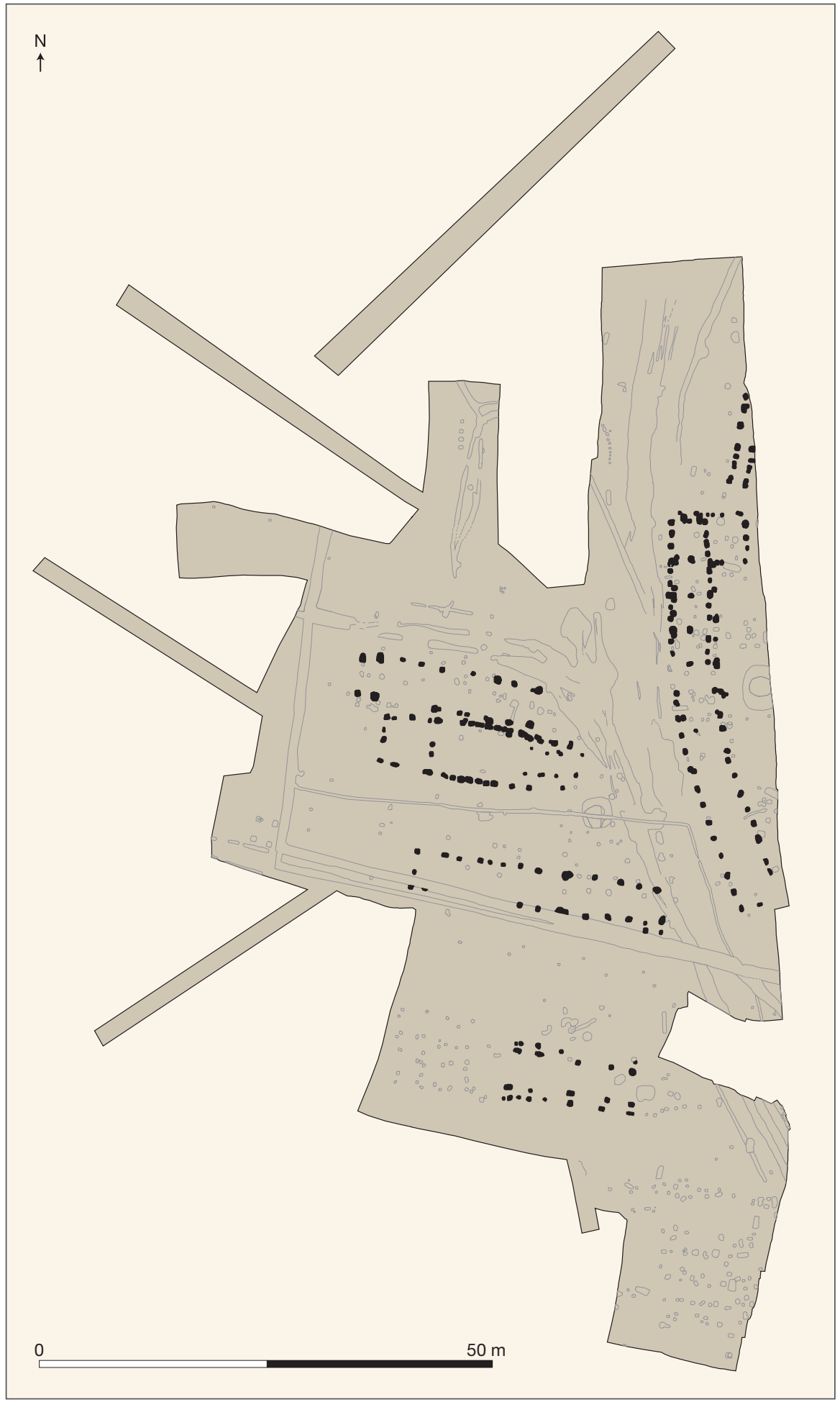


Det antyder, at dateringsrammen for flere af hustomterne må udvides opefter i tid til helt op til 1700-årene, da senere udgravninger har vist, at byggeskikken med jordgravede stolper fortsatte betydeligt længere end tidligere antaget. ${ }^{52}$ Et andet og vigtigt resultat er, at udgravningen demonstrerer, at strukturen $i$ landsbyerne på de ældste matrikelkort i nogle tilfælde kan have meget dybe rødder.

\section{Den middelalderlige landsbebyggelse i la longue durée}

Den ovenstående gennemgang viser, at vi fortsat er langt fra at have samme overblik over den middelalderlige landbebyggelse, som vi har for de forudgående perioder. Eksemplerne fra Gl. Hviding, Lustrup og Vilslev synes ikke at udvise en strukturel kontinuitet rækkende fra middelalderen og frem til landsbyerne afbildet på Original 1-kortene, mens det modsatte var tilfældet i Hunderup. Man kan konstatere, at der i nogle tilfælde kan være lang kontinuitet og i andre ikke. ${ }^{53}$

En anden central iagttagelse er, at middelalderens landsbyer udgør mere komplekse udgravningsobjekter, end de forudgående perioders. Konklusionen på forholdene i jernalderen var, at det er lykkedes at udgrave og udrede nogle af de mindre bebyggelser, mens vi endnu kun har begrænsede indblik i de komplicerede forhold i en stor adelby. I middelalderen er tofterne ofte større, og udgravningerne kompliceres af at finde sted inde i eller i umiddelbar tilknytning til en historisk landsby, som begrænser mulighederne for store, sammenhængende fladeafdækninger markant. Og der er næppe grund til at tro, at den middelalderlige landsby var væsentligt mindre end de senere faser. Således er der behov for enorme udgravninger for at forstå hele strukturen. Det hele kompliceres yderligere af problemstillingen omkring brugen af jordgravede stolper i forhold til huse placeret på syldsten.

De ovenstående forhold har som konsekvens, at de mest komplet afdækkede middelaldergårde er de, som af den ene eller anden grund ikke udgjorde en

$\leftarrow$ Fig. 23. Det sydlige af udgravningsfelterne i Hunderup. Husene er noget mindre end de ovenfor omtalte eksempler fra Vilslev og Hviding, formentlig en afspejling af, at Hunderup er et indlandssogn. Udgravningen ASR 1442, Møllevænget.

The southern excavation trench at Hunderup. The buildings are somewhat smaller than those at Vilslev and Hviding. This difference in size is common when comparing coastalmarsh settlements with inland settlements. 
bæredygtig struktur, mens de egentlige succeshistorier under de eksisterende landsbyer i højere grad er undveget arkæologernes graveskeer. Dette misforhold må holdes in mente, men det her anvendte lange tidsperspektiv kan udpege en række gennemgående strukturer.

Kontinuitetstrækkene omtalt ovenfor må betyde, at også de middelalderlige landsbyer, om de så er udgravet eller ej, fulgte det samme generelle mønster. Der er ikke stærke argumenter for at hævde, at ikke også middelalderens landsbyer bestod af familiebrug, som i fællesskab dyrkede et afgrænset landområde med agerjord, der i Vestjylland hovedsagelig var i omdrift som græsmarksbrug. I ejerlavene med adgang til marsken må dyreholdet og hermed også produktion af mælkeprodukter, uld og læder have spillet en større rolle end længere inde $i$ landet.

\section{Gårdene og deres tofter}

Landskabslovenes omtaler af gårdenes tofter og rebning som metode til opmåling og fordeling af jord viser, at tofterne på dette tidspunkt var strengt regulerede arealer, som under optimale udgravningsforhold i detaljer burde kunne udredes og afsløre landsbyens ejerskifter, arvehistorik og udvikling. ${ }^{54}$ Mest overbevisende er en sådan udredning foretaget på lokaliteten Østergaard (Hyrup), hvor grundlæggergårdens opdeling i hele 10 gårdsanlæg i tidsrummet ca. 1000-1200 kan følges..$^{55}$ Tolkningen hviler på en lang række såkaldt horisontalstratigrafiske overvejelser og er som sådan behæftet med usikkerhed, men der er ingen tvivl om, at udviklingen bevæger sig fra én gård, som opdeles i flere. Ét karakteristisk træk er, at der igennem en tidligere hovedbygnings midte føres en ny toftegrænse som markering af gårdens deling $i$ to.

Hvor langt tilbage denne tankegang omkring toften kan føres er et vigtigt spørgsmål, som ikke skal forsøges besvaret i denne sammenhæng, men de mere sikre tilfælde synes at stamme fra ældre middelalder, ${ }^{56}$ mens de mange landsbyer fra yngre romersk jernalder-vikingetid ikke synes at være hverken opmålt eller have skiftet hænder efter denne metode. ${ }^{57}$ Landskabslovenes arvedelingsregler harmonerer også dårligt med, at gårdsantallet i ejerlavene synes at have været relativt konstant. Hvis begge udsagn er korrekte, ville det kræve middelalderlig familieplanlægning i et omfang, der hverken synes realistisk eller er behagelig at tænke på.

Der er heller ikke en 1:1 sammenhæng mellem toftestørrelser og socialt niveau. Særligt i 11. og 12. århundrede er der en række eksempler på meget store tofter, mens de i tæt bebyggede adelbyer som Vilslev synes at have været mindre. 

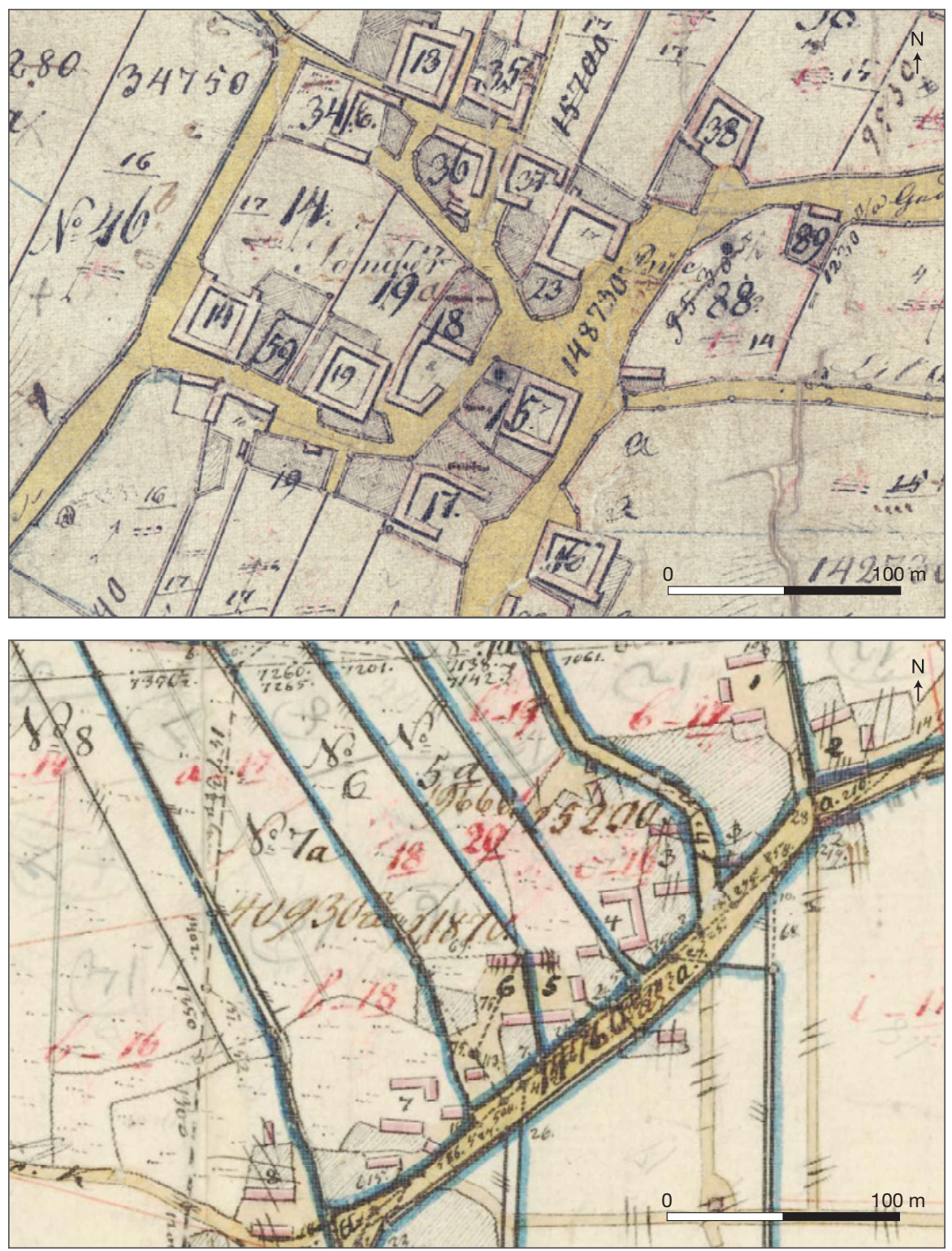

Fig. 24. Øverst et udsnit af Original 1-matrikelkortet over "Store Darum Bye" (Darum sogn, Gørding Herred), opmålt 1820. Det viser et udsnit af Sønderby, som bestod af ret velvoksne gårde. Nederst et udsnit af Original 1-matrikelkortet over "Sønder Veirup Mark" fra 1818 (Vejrup sogn, Gørding Herred), som bestod af ret små gårde. Denne forskel mellem gårdene i marsken og på heden er en generel tendens, som svarer til de økonomiske forskelle, kirkelisten i Ribe Oldemoder udtrykker (fig. 4). Forskellene kan også spores i jernalderens landsbyer. - Efter original i Geodatastyrelsen.

Top: An excerpt from the first cadastral map of "Store Darum Bye" (Darum parish, Gørding hundred) from 1820. It depicts Darum Sønderbye with rather large farmsteads. Bottom: An excerpt from the first cadastral map of "Sønder Veirup Mark" from 1818 (Vejrup parish, Gørding hundred). It depicts rather small farmsteads. This difference in size between coastal-marsh settlements and heath settlements is a general phenomenon reflecting the economic differences seen in the church list of 1325 (fig. 4) and extending all the way back to the Iron Age. 


\section{Bygningerne}

Original 1-kortene fra Sydvestjyske Museers ansvarsområde fra omkring år 1800 afbilder de enkelte gårde med stor præcision, og sammenligninger med bevarede, stående bygninger og udgravninger i landsbyerne har vist, at man kan fæstne lid til, at bygningerne på matrikelkortet rent faktisk afspejler den stående bygningsmasse i det pågældende tidsrum. ${ }^{58}$ Forskellige syns- og skifteforretninger giver desuden et detaljeret indblik i både gårdenes indretning, inventar, dyrehold m.m. ${ }^{59}$

På denne tid var der en tydelig sammenhæng mellem landskabets ydeevne og bondegårdenes størrelse (fig. 24). Inde på heden var bøndernes huse korte og smalle, og længerne var få, mens marsklandsbyernes bønder boede i større, ofte firlængede gårde. Ingen steder var gårdene helt uniforme. Længeantal og bygningsareal varierede, og formentlig afspejler det, at området primært var sædvanereguleret. Også fæstebønder kunne eje deres egne bygninger, og de enkelte familier vedligeholdt, ombyggede eller nybyggede deres gårde, som de havde økonomi, held og evner til. Sådan er det også i dag, men landskabets ydeevne som begrænsende faktor er erstattet af nutidens overmål af næringsstoffer (fig. 25).

Også i middelalderen kan der iagttages en tydelig sammenhæng imellem landskabet og bygningernes størrelse. Den største gård i den yngste fase af Vorbasselandsbyen, der er foreslået som en stormandsgård, ${ }^{60}$ er en beskeden

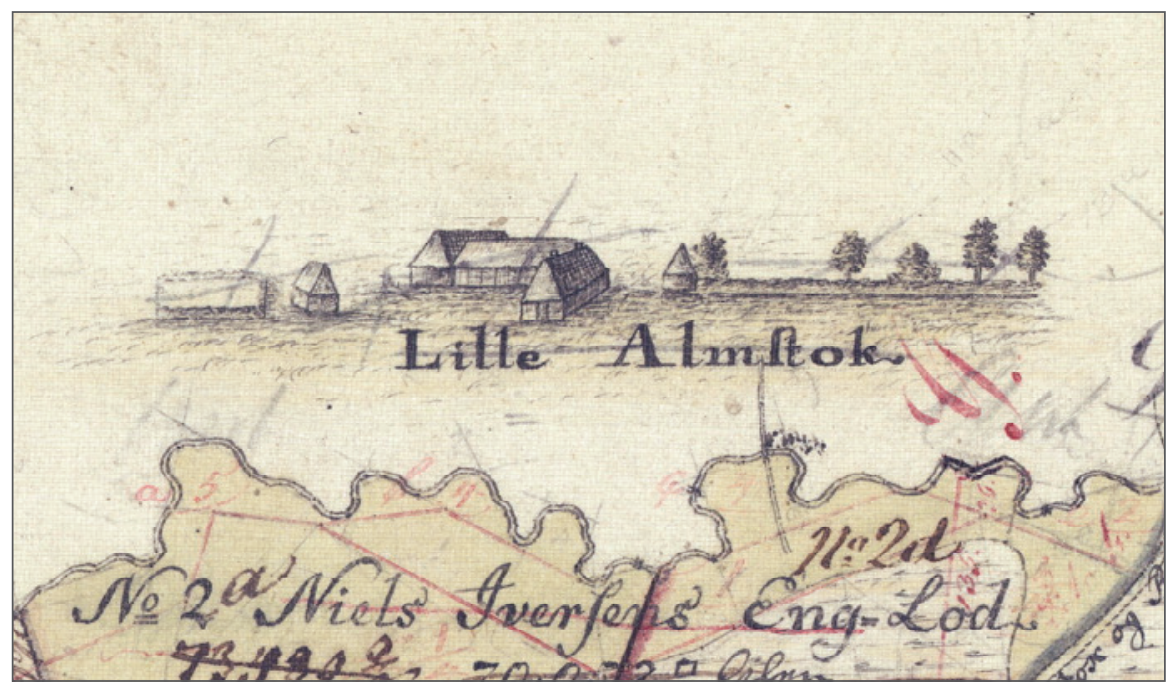

Fig. 25. Gården Ll. Almstok i Vorbasse sogn afbildet på Original 1-kortet fra naboejerlavet Moltkenberg, opmålt 1799. - Efter original i Geodatatyrelsen.

The farmstead Little Almstok in Vorbasse parish, depicted on the first cadastral map of Moltkenberg from 1799. 

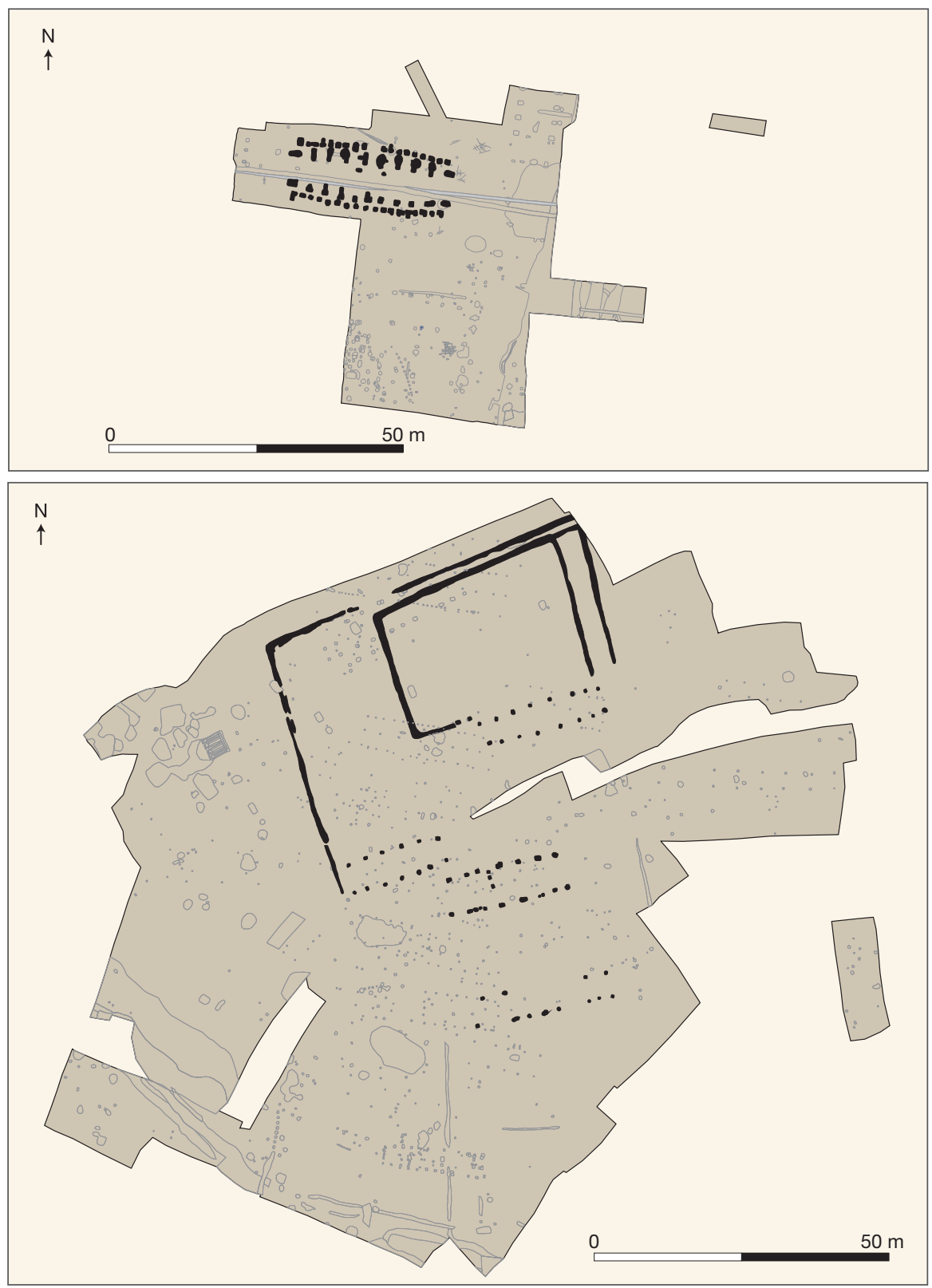

Fig. 26. En stor gård i marsken og små gårde på heden. Øverst ASR 2259, Sprækvej, V. Vedsted, udgravet 2007. Hustypologisk datering: Ca. 1100. Nederst SJM 385, Ravnsbjerg, Guldager, udgravet 2015-2017. Tre på hinanden efterfølgende gårdsfaser med tilknyttede indhegninger. C14-dateret til 13. århundrede.

A large farmstead in the coastal marshland and small farmsteads on the heathland. Top: ASR 2259 Sprækvej, Vester Vedsted parish, excavated in 2007. Dated typologically to c. 1100. Bottom: SJM 385 Ravnsbjerg, Guldager parish, excavated in 2015-17. Three successive phases with associated crofts. ${ }^{14} \mathrm{C}$ dated to the 13 th century. 
bygning på knap 22 meters længde $\left(125 \mathrm{~m}^{2}\right)$, en dværg ved siden af den samtidige gårdfase 3 i Hviding (fig. 16c), hvor hovedhuset målte $32 \mathrm{~m} \mathrm{(235} \mathrm{m²)}$ og endda var den mindste af de fire udgravede faser (fig. 26).

Igennem både jernalder og vikingetid bestod en gård af en hovedbygning, som, afhængig af de forskellige perioders byggeskik, kan have bevarede båseskillerum i typisk østenden, mens fund af ildsteder m.m. viser, at beboelsen lå i husets vestlige, eller centrale del. Til dette Wohnstallhaus kunne høre forskellige udhuse, hegnshuse eller halvtagshegn.$^{61}$

I tidlig moderne tid bestod en gård af et stuehus, som i Vestjylland kaldtes et salshus. ${ }^{62}$ I 1600 -tallet lå stald og beboelse i samme længe på de mindre gårde, mens de større gårde havde staldafsnittet placeret i en separat længe. Hertil kunne slutte sig forskellige andre længer, som, når gården var stor nok, dannede et omtrent kvadratisk, firlænget anlæg omkring en gårdsplads, hvor møddingen lå. I udgravninger i Sydvestjylland kan gårde af denne type følges ubrudt tilbage til 1500-årene, og typisk var det bindingsværksbygninger med jordgravede stolper. ${ }^{63}$

For det mellemliggende tidsrums vedkommende, middelalderen, har vi langt dårligere kendskab til bygningernes indretning, da den oftest ikke har afsat spor i undergrunden, men strukturelt identiske planløsninger både før og efter gør det mindre sandsynligt, at hovedhuset ikke også, som hovedregel, har indeholdt stald og beboelse, mens eventuelle andre bygninger kunne anvendes som lade, lo m.m. Fra ældre middelalder og frem ses 2-skibede hegnshuse, svarende til de 2-skibede økonomibygninger, der er påvist på gårdene fra 1500-årene (sammenlign fig. 16d). ${ }^{64}$ Her må der være tale om sulehuse, hvis åbne tagkonstruktion antyder en brug som lader.

Forandringerne i husenes arkitektur igennem vikingetid og middelalder ser ud til at udgøre en gradvis udvikling, hvor tagbærende stolper inde i bygningen først reduceres i antal, før de forsvinder helt. Og Trelleborghusenes ydre, skrå støttestolper udvikles til udskud i takt med, at tagets vægt placeres på stolper i væglinjen. ${ }^{65}$

Huse af disse typer er påvist på mange lokaliteter i både det sydlige og vestlige Jylland (fig. 27). I de fleste tilfælde er dateringsgrundlaget forholdsvist spinkelt, men udviklingen synes at følge det samme generelle mønster. Det er med til at vise, at forestillingen om en gårds bygninger, deres konstruktion og udseende, udgjorde en fælles og kommunikeret forestilling over større geografiske områder. Og særligt i tidsrummet ca. 1000-1200 synes der at ske en markant udvikling af arkitekturen, som falder sammen med en lang periode med godt vejr og generel højkonjunktur. 


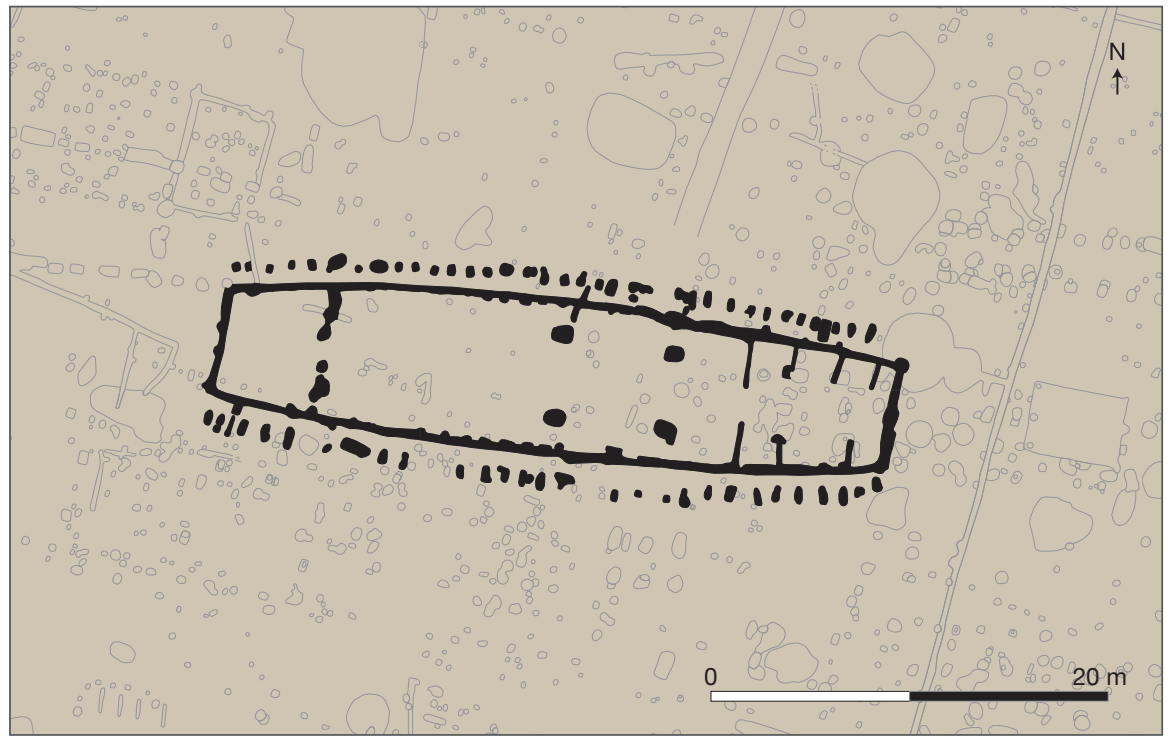

Fig. 27a. Trelleborg-type hus. ASR 440, Gl. Hviding, hus I. Omkring år 1000.

Trelleborg-type building, ASR 440, Gammel Hviding, building I, c. AD 1000.

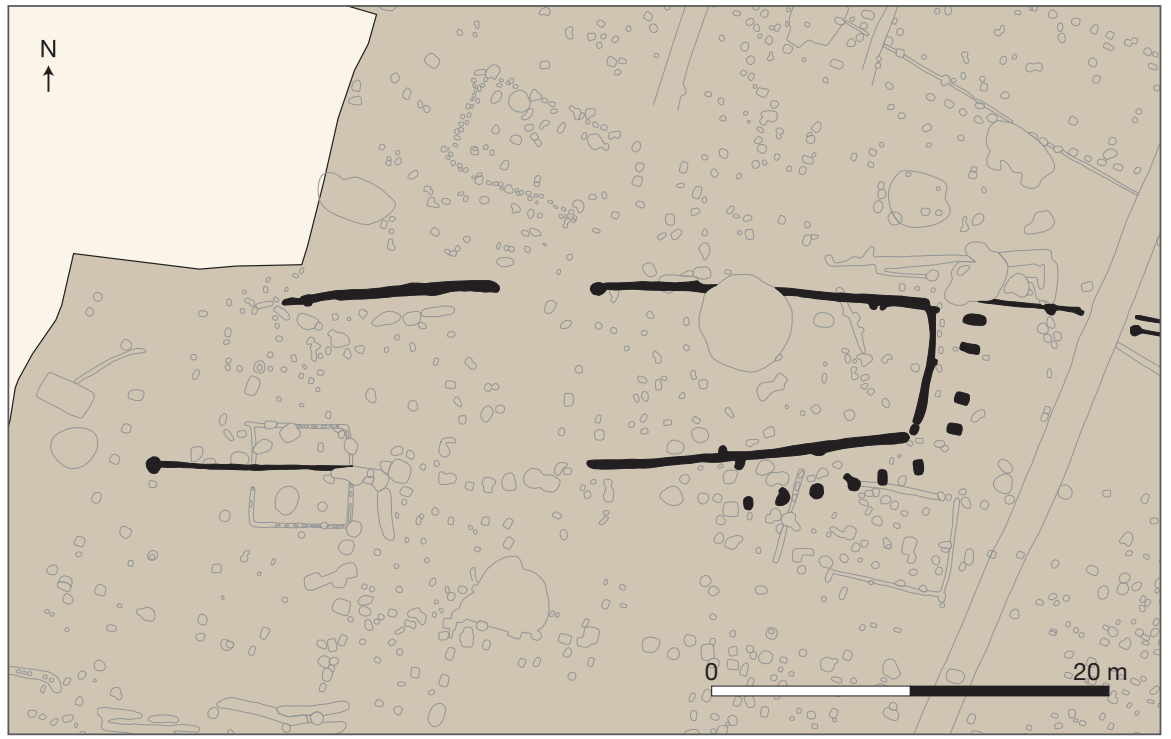

Fig. 27b. Væggrøfthus med buede langvægge. ASR 440, Gl. Hviding, hus VIII. Første halvdel af 11. århundrede.

Building with a wall trench, ASR 440, Gammel Hviding, building VIII, first half of the 11th century. 


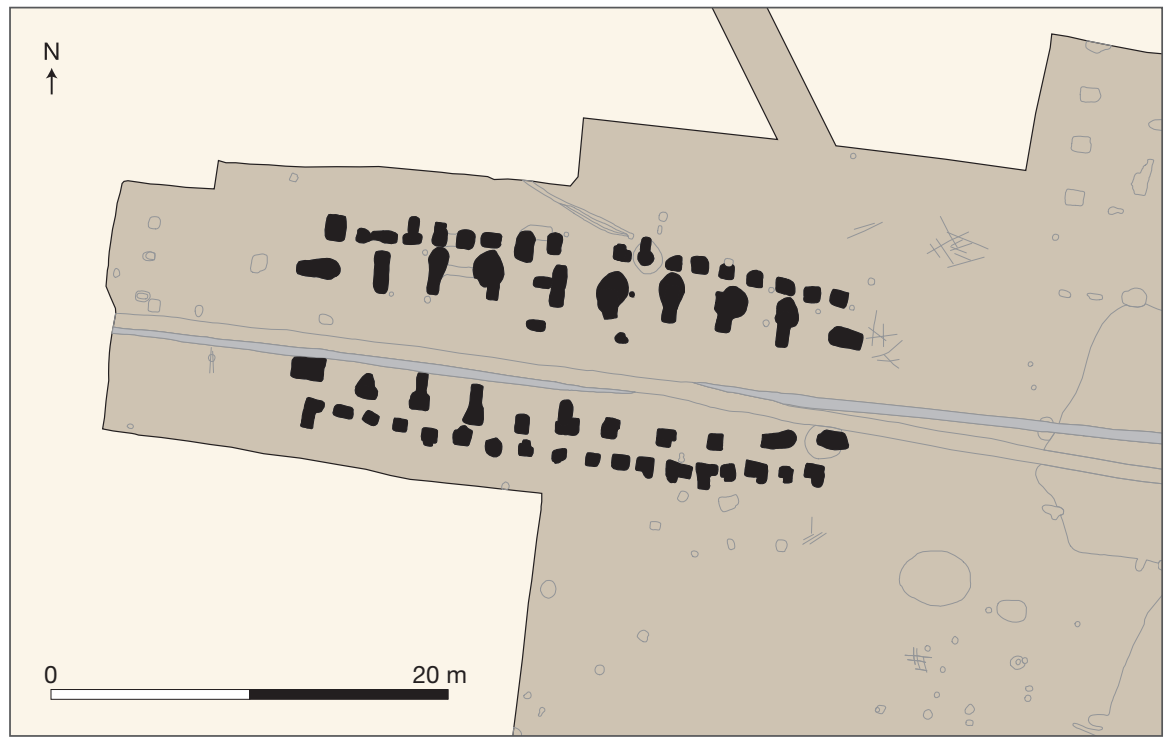

Fig. 27c. Fuldt udskudshus, buede langvægge. ASR 2259, Sprækvej, Hus I. Omkring år 1100.

Building with curved side walls and outshot. ASR 2259, Sprækvej, building I, c. AD 1100 .

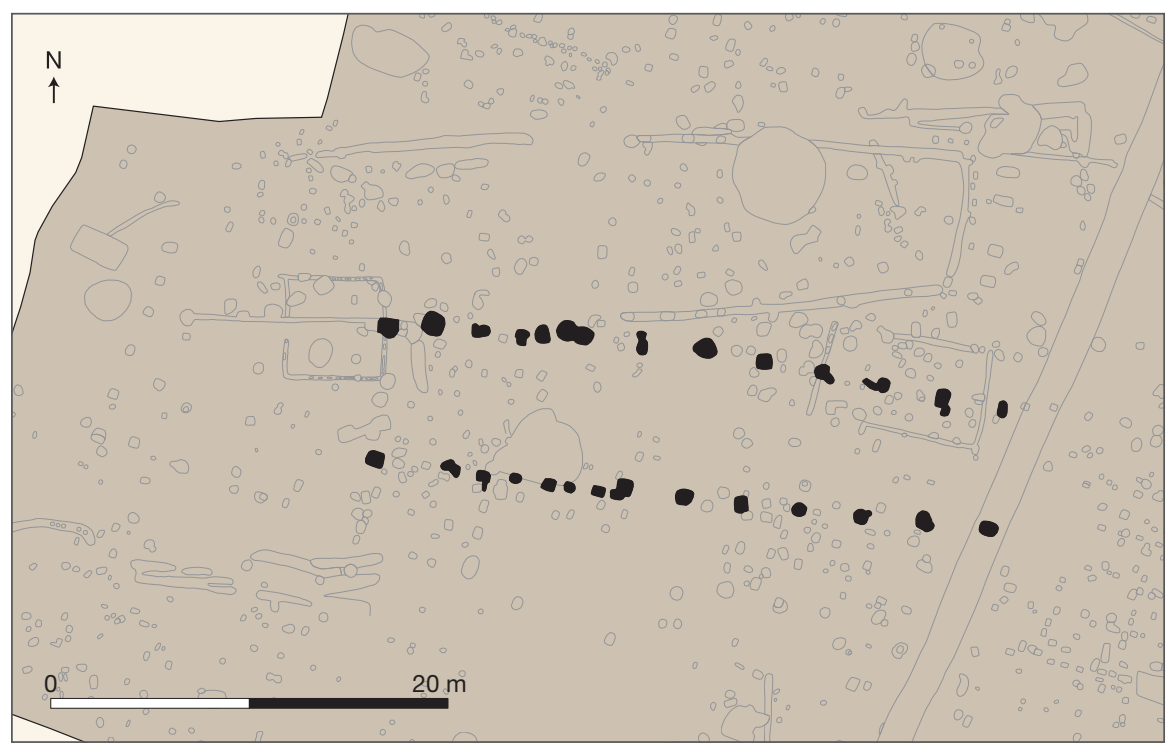

Fig. 27d: Buede langvægge, tagbærende stolper i væglinjen. ASR 440, Gl. Hviding, hus XII. Omkring år 1100.

Curved side walls. Postholes for roof-bearing posts in the wall. ASR 440, Gammel Hviding, building XII, c. AD 1100. 


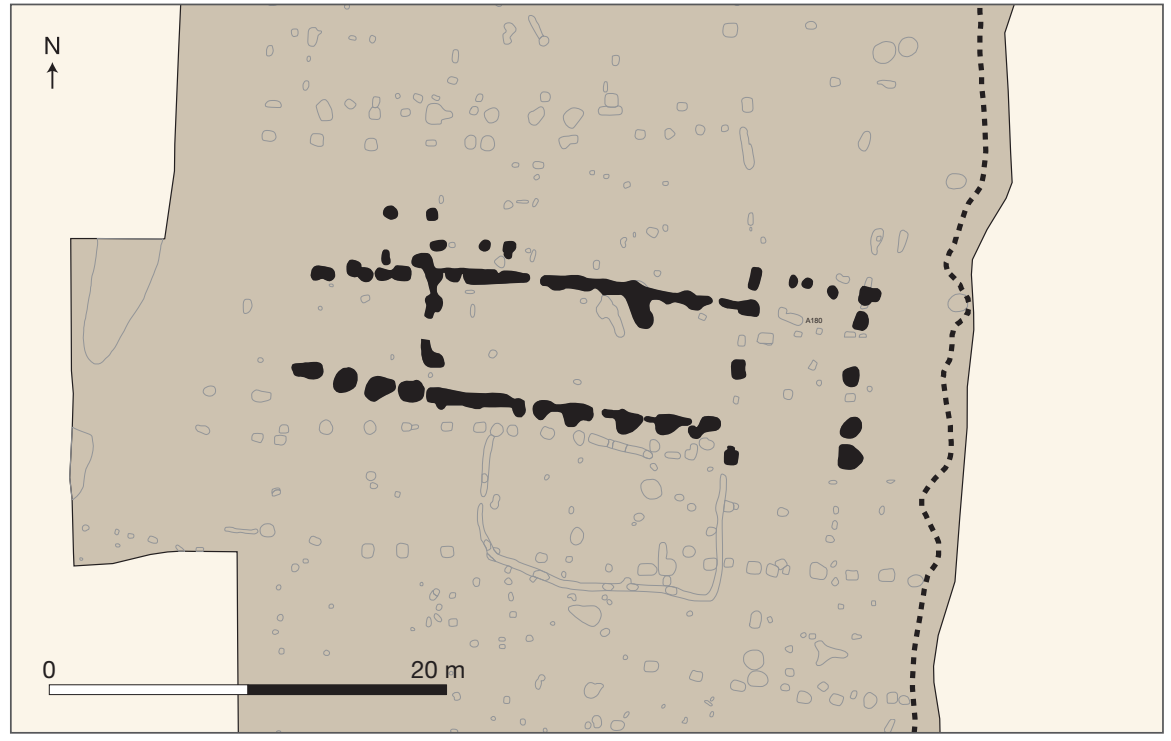

Fig. 27e. Buede langvægge, muligt portrum i den ene ende. ASR 491, Vilslev, hus C. Første halvdel af 12. århundrede.

Curved walls, possible gatehouse at one end. ASR 491, Vilslev, building C. First half of the 12 th century.

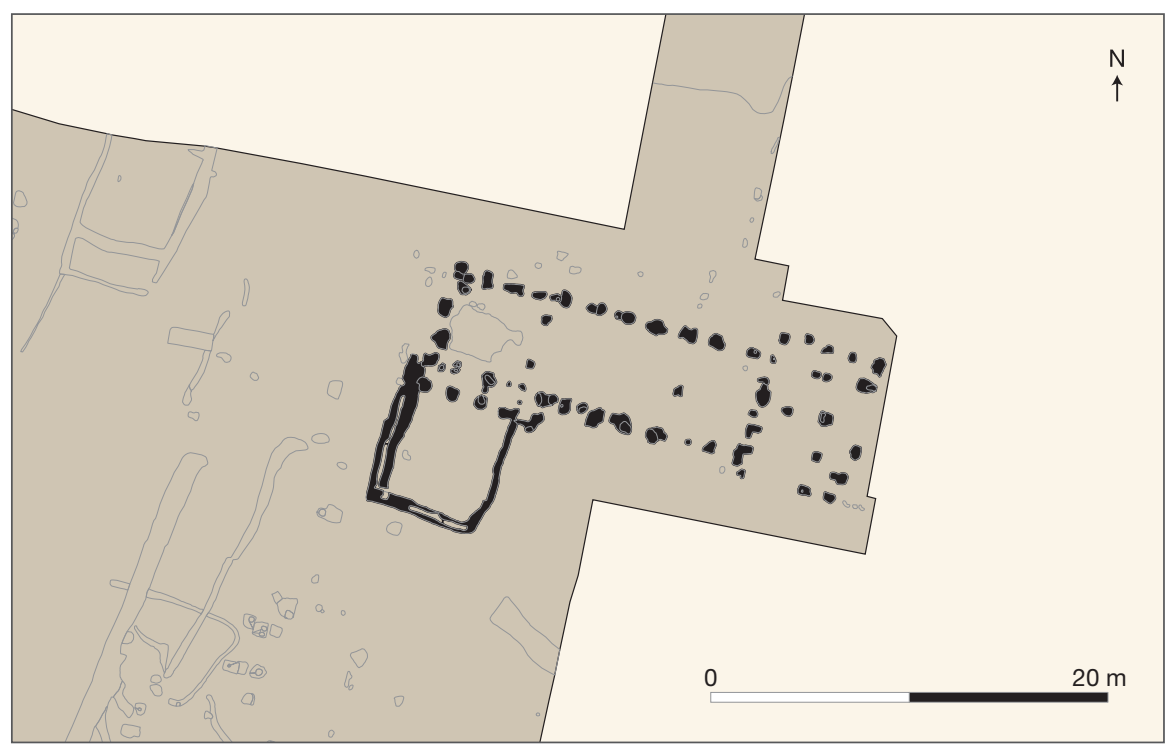

Fig. 27f. Rette langvægge, muligt portrum i den ene ende. ASR 270, Nr. Farup, hus I. Anden halvdel af 12. århundrede.

Straight side walls, possible gatehouse. ASR 270, Nørre Farup, building I. Second half of the 12 th century. 


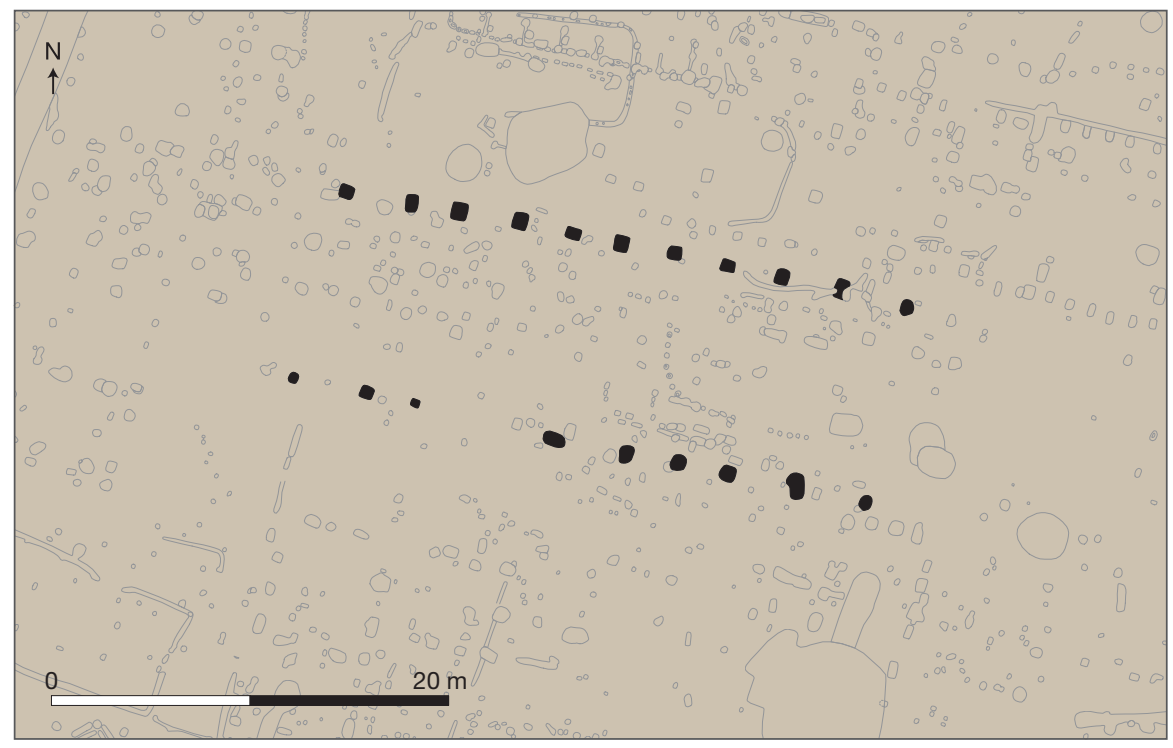

Fig. 27g. Rette langvægge. ASR 440, Gl. Hviding, hus XXXIV. Anden halvdel af 12. århundrede.

Straight walls. ASR 440, Gammel Hviding, building XXXIV. Second half of the 12th century.

Samtidig er det vigtigt at holde sig den ret varierende skala for øje. Hovedhusenes længder kan svinge fra 15 til $40 \mathrm{~m}$, svarende til bygningsarealer fra under 100 til over $300 \mathrm{~m}^{2}$, hvilket afspejler tilsvarende økonomiske og sociale forskelle gårdene imellem.

\section{Middelaldergårde og socialstruktur i la longue durée}

I et tidsperspektiv, som omfatter de to seneste årtusinder, synes de største brud i den vestjyske bebyggelsesstruktur at være klimakrisen efter 536 og den sorte død i 1350. Begge katastrofer ser ud til at have haft større betydning for indbyggerantal og bebyggelsesudvikling, og dermed de arkæologiske levn, end teknologiske, politiske eller religiøse forandringer som indførelsen af muldfjelsploven, fremkomsten af en kongemagt eller trosskiftet.

Siden 1970'erne har ét centralt spor i udforskningen af den middelalderlige landbebyggelse været præget af, at samfundet anskuedes som en lagdelt pyramide, og det agrare landskabs aktører opdeltes i stormænd og derunder bønder. Mange kræfter er sat ind på at lede efter forgængerne til de stormænd, som i anden halvdel af 1200-årene og 1300-årene flyttede ud i mosen på en hverken særligt komfortabel eller repræsentativ sumpborg. ${ }^{66}$ 
Imidlertid svarer dette binære modsætningspar, bonde eller stormand, ikke godt til det arkæologiske materiale fra ældre middelalder, der som i jernalder og vikingetid i overvejende grad afdækkede forholdsvis velvoksne gårde og tofter, som hverken syntes at passe til en undertrykt bonde eller en magtfuld stormand, selv om den sidste tolkning nogle gange er forsøgt. ${ }^{67} \mathrm{Og}$ hvordan skulle man tolke det forhold, at der lå to samtidige, meget store gårde som naboer. ${ }^{68}$ De kunne vel næppe begge udøve magt over hinanden?

Som denne tekst har søgt at vise, synes forholdene i ældre middelalder i højere grad at være en videreførelse af forholdene fra jernalder og vikingetid. Frem for at være stormænd og bønder synes folk på landet at have været én stor og differentieret gruppe af såkaldt/relativt frie bønder, hvis agrare ageren fulgte gamle mønstre.

Til dette system introduceredes tiende og forestillingen om ejendomsret til jord i tidsrummet 11.-13. århundrede, og fra anden halvdel af 13. århundrede voksede adelen frem. ${ }^{69}$ Disse udviklinger var (mere) ulighedsskabende og kom til at forandre det agrare landskab. Men ikke mere end at lighederne imellem jernalderlandsbyerne og landsbyerne på de ældste kort er åbenbare. Igennem hele perioden blev bønderne ved med at dyrke landet, som de altid havde gjort.

De egentlige aristokrater fandtes også, og udgravningerne af Ribebispens gård i Lustrup viser, at vi på disse fåtallige, egentlige storgårde kan forvente både stenhuse og enorme bygninger, som klart hæver sig over selv rige bønders formåen. Men der var langt imellem disse særlige gårde, og da levnene efter dem ofte skal findes inde i de historiske landsbyer eller ved senere herregårde, er de i endnu mindre grad end den øvrige landbebyggelse blevet mål for arkæologiske undersøgelser i et omfang, som afslører deres omfang og struktur. ${ }^{70}$

\section{NOTER}

1. Braudel \& Wallerstein 2009.

2. Behre 2008, s. 19ff; Eriksen m.fl. 2009, s. $17 \mathrm{ff}$.

3. Büntgen m.fl. 2016.

4. Clemmensen 2005; Fruergaard m.fl. 2013.

5. Møller 2000.

6. Behre 2008, s. 106ff.

7. Møller 2000; Eriksen m.fl. 2009, s. $17 \mathrm{ff}$.

8. Nielsen 1869; Nyborg 1986.

9. Severinsen 1921; Skyum-Nielsen 1949; Kieffer-Olsen 2018, s. $399 \mathrm{ff}$.

10. Kinch 1869, s. 196; Poulsen 2003b, s. 493 f.

11. Søvsø 2008; Søvsø 2009. 
12. Sml. Brøndsted 1960; J. Jensen 2003; J. Jensen 2004; https://slks.dk/omraader/kulturarv/arkaeologi-fortidsminder-og-diger/arkaeologi-paa-land/arkaeologiske-strategier/jernalder-aej-500-fkr-400-ekr-yj-400-800-ekr-vikingetid-800-1050-ekr/.

13. Feveile 2018; Søvsø 2018; Trier Christiansen 2018.

14. Siemen 1990; Siemen 1993; Siemen \& Stoumann 1996a; Siemen \& Stoumann 1996b; Siemen 2000.

15. Hvass 1988; J. Jensen 2003, s. $22 \mathrm{ff}$.

16. Siemen \& Stoumann 1996a.

17. L. Jørgensen 2014.

18. Egeberg 1996; Grundvad m.fl. 2017; Søvsø 2019.

19. Agersnap Larsen 2015.

20. https://www.geus.dk/produkter-ydelser-og-faciliteter/data-og-kort/danske-kort/ download-jordartskort/.

21. Siemen 1990, s. 66.

22. Hoff 1997, s. $124 \mathrm{ff}$.

23. Skovgaard-Petersen 1977, s. 207ff; Fenger 1989, s. 113ff; Poulsen 2003a, s. 376ff.

24. Albøge 2000; B. Jørgensen 2008.

25. Hvass 1979; Hvass 1980; Stoumann 1980; Hvass 1988.

26. Hvass 1979.

27. Sørensen 2011.

28. Qvistgaard 2010; Grundvad \& Qvistgaard 2016.

29. Siemen \& Stoumann 1996b.

30. Stoumann 1980.

31. Näsman 1991.

32. Ørsnes 1966; Axboe 2001; Gräslund \& Price 2012.

33. Kinch 1869, s. 196.

34. Hvass 1985; Hvass 1988; se diskussion i Holst 2010 samt Poulsen \& Sindbæk 2011.

35. Wickham 2005, s. 370.

36. Svart Kristiansen 2003.

37. Nyborg 1979; Fenger 1989, s. 113ff; Poulsen 2003a, s. 393ff.

38. Weibull 1911; Koch 1936.

39. Poulsen \& Sindbæk 2011; Jørgensen 2014.

40. Søvsø 2011.

41. Søvsø 2008; Søvsø 2009; Alrø Jensen 2019.

42. S. Jensen 1987; Søvsø 2011.

43. Krogh 1964.

44. Jeppesen \& Madsen 1997.

45. Søvsø 2011; Søvsø 2018.

46. Feveile \& Bennike 2002.

47. Søgaard 1973; Søvsø 2013.

48. Sørensen 2003.

49. Kinch 1869, s. 603. 
50. Jensen 1987.

51. Feveile \& M.H. Søvsø 2009.

52. Søvsø 2009; Alrø Jensen 2019.

53. Hansen 2011.

54. Hoff 1997, s. 84ff.

55. Sørensen 2011, s. $289 \mathrm{ff}$.

56. Hansen 2011; Sørensen 2011 samt fig. 26.

57. Holst 2010.

58. Alrø Jensen 2019.

59. Vensild 2004, s. 102ff; Porskrog Rasmussen 2013, s. $368 f f$.

60. Hvass 1980, s. $166 \mathrm{ff}$.

61. Ethelberg 2003.

62. Vensild 2004, s. 102.

63. Søvsø 2008; Søvsø 2009, Alrø Jensen 2019.

64. Madsen 1985; Søvsø 2009.

65. Skov 1994; Klemensen 2003; Eriksen m.fl. 2009, s. 222.

66. Poulsen 2003b, s. 506; Kock 2005; Poulsen \& Sindbæk 2011.

67. Sørensen 2011.

68. L.C. Nielsen 1980.

69. Vogt 2017.

70. Tak til Deutsches Archäologisches Institut i Berlin, som gennem et gæsteforskerophold i sommeren 2019 støttede dette arbejde.

\section{LITTERATUR}

Agersnap Larsen, L. 2015: Muldfjælsplovens tidlige historie. Fra yngre romersk jernalder til middelalder. Kuml, s. 165-200.

Albøge, G. 2000: Stednavne. I: K. Dalsgaard, P. Eriksen, J.V. Jensen og J.R. Rømer (red.): Mellem hav og hede. Landskab og bebyggelse i Ulfborg herred indtil 1700. Aarhus, s. 112-124.

Alrø Jensen, M. 2019: Den gamle Ulvegaard i Tjæreborg og to andre eksempler på bøndergårde med jordgravede stolper fra tidlig moderne tid. By, marsk og geest 31, s. 44-70.

Axboe, M. 2001: Amulet Pendants and a Darkened Sun. I: B. Magnus (red.): Roman Gold and the Development of the Early Germanic Kingdoms: Aspects of Technical, Sociopolitical, Socio-economic, Artistic and Intellectual Development, A.D. 1-500. Stockholm, s. 51.

Braudel, F. \& I. Wallerstein 2009: History and the Social Sciences: The Longue Durée. Review (Fernand Braudel Center), vol. 32, nr. 2, Commemorating the longue durée, s. 171-203.

Brøndsted, J. 1960: Danmarks Oldtid. III. Jernalderen. 2. udgave. København.

Büntgen, U. m.fl. 2016: Cooling and societal change during the Late Antique Little Ice Age from 536 to around 660. Nature Geoscience 9, s. 231-236. 
Clemmensen, L. 2005: Sandflugt ved Jyllands vestkyst gennem årtusinder. Geoviden 3:2005, s. 10-15.

Egeberg, T. 1996: Et jernalderhus med drikkeglas i Dejbjerg, Vestjylland. Kuml 1993-94 (1996), s. 211-236.

Eriksen, P., T. Egeberg, L.H. Olesen \& H. Rostholm 2009: Vikinger i vest. Vikingetiden $i$ Vestjylland. Højbjerg.

Ethelberg, P. 2003: Gården og landsbyen i jernalder og vikingetid (500 f.Kr.-1000 e.Kr.). I: L.S. Madsen \& O. Madsen (red.): Det Sønderjyske Landbrugs Historie. Jernalder, Vikingetid og Middelalder. Haderslev, s. 123-374.

Feveile, C. 2018: Nordøstfyn - fra ingen til mange metalrige pladser på få år. I: V. Hilberg \& T. Lemm (red.): Viele Funde - grosse Bedeutung? Bericht des 33.Tværfaglige Vikingesymposiums. Kiel, s. 29-48.

Feveile, C. \& P. Bennike 2002: Lustrupholm - et brandgravfelt fra ældre bronzealder under flad mark. Kuml, s. 109-141.

Feveile, C. \& M.H. Søvsø 2009: Vikingetidsgravpladsen ved Hunderup - 15 jordfæstegrave omkring en storstensgrav fra stenalderen. By, marsk og geest 21, s. 33-48.

Fenger, O. 1989: Gyldendal og Politikens Danmarkshistorie. Bind 4. "Kirker rejses alle vegne". København.

Fruergaard, M. m.fl. 2013: Superstormen i 1634. Geoviden 3, s. 2-5.

Grundvad, B. \& S. Qvistgaard 2016: Andrups Arkæologi - kontinuerlig bebyggelse fra neolitikum til germansk jernalder. Arkcoologi i Slesvig - Archäologie in Schleswig 16, s. 101-114.

Grundvad, L., N. Schaadt \& B. Ejstrud: Festedskatten - Danmarks største guldskat fra vikingetiden. Aarhus.

Gräslund, B. \& N. Price 2012: Twilight of the gods? The 'dust veil event' of AD 536 in critical perspective. Antiquity 86, s. 428-443.

Hansen, J. 2011: Rynkeby - 14C-dateringer i en fynsk landsby med stedkontinuitet fra yngre germansk jernalder. Fynske Minder, s. 95-103.

Hoff, A. 1997: Lov og Landskab. Landskabslovenes bidrag til forståelsen af landbrugs- og landskabsudviklingen i Danmark ca. 900-1250. Aarhus.

Holst, M.K. 2010: Inconstancy and stability - large and small farmsteads in the village of Nørre Snede (Central Jutland) in the first millennium AD. Siedlungs- und Kïstenforschung im südlichen Nordseegebiet vol. 33, s. 155-179.

Hvass, S. 1979: Die Völkerwanderungszeitliche Siedlung Vorbasse, Mitteljütland. Acta Archaeologica 49, 1978, s. 61-111.

Hvass, S. 1980: Vorbasse. The Viking-age Settlement at Vorbasse, Central Jutland. Acta Archaeologica 50, 1979, s. 137-172.

Hvass, S. 1985: Hodde. Et vestjysk landsbysamfund fra celdre jernalder. København.

Hvass, S. 1988: Jernalderens bebyggelse. I: P. Mortensen \& B.M. Rasmussen (red.): Fra Stamme til Stat i Danmark, bd. 1. Højbjerg, s. 53-92.

Jensen, J. 2003: Danmarks Oldtid. Aldre Jernalder 500 f.Kr.-400 e.Kr. København.

Jensen, J. 2004: Danmarks Oldtid. Yngre Jernalder og Vikingetid 400 e.Kr.-1050 e.Kr.

København.

Jensen, S. 1987: Gårde fra vikingetiden ved Gl. Hviding og Vilslev. Mark og Montre 1986-87, s. 5-26.

Jeppesen, J. \& H.J. Madsen 1997: Trækirke og stormandshal i Lisbjerg. Kuml 1995-96, s. 149-171. 
Jørgensen, B. 2008: Danske stednavne. 3. udgave. København.

Jørgensen, L. 2014: Norse Religion and Ritual Sites in Scandinavia in the 6th-11th century. I: H.C. Gulløv (red.): Northern Worlds - Landscapes, Interaction and Dynamics - Proceedings of the Northern Worlds Conference, Copenhagen 28-30 November 2012. København, s. 129-150.

Kieffer-Olsen, J. 2018: Kirke og kirkestruktur i middelalderens Danmark. Odense.

Kinch, J.F. 1869: Ribe Bys Historie og Beskrivelse indtil Reformationen. Ribe.

Klemensen, M.F. 2003: Bondehuse fra tidlig middelalder i Jylland - fra et arkæologisk perspektiv. Bol og By 1-2, s. 31-45.

Koch, H. 1936: Danmarks Kirke i den begyndende Højmiddelalder, bd. I-II. København.

Kock, J. 2005: Borgforskning og Boringholm. I: J. Kock \& E. Roesdahl (red.): Boringholm - en østjysk treeborg fra 1300-årene. Højbjerg, s. 27-34.

Krogh, K. 1964: De faldt ned midt udi sommeren. Skalk 3, s. 14-20.

Madsen, P.K. 1985: Houses from the later Part of the Twelfth Century at Farup near Ribe, South-West Jutland. Journal of Danish Archaeology, vol 4, s. 168-178.

Møller, J.T. 2000: Engang en del af havet: Fjorde og søer i Ulfborg herred. I: K. Dalsgaard, P. Eriksen, J.V. Jensen og J.R. Rømer (red.): Mellem hav og hede. Landskab og bebyggelse i Ulfborg herred indtil 1700. Aarhus, s. 36-58.

Nielsen, L.C. 1980: Omgård. A Settlement from the Late Iron Age and the Viking Period in North-west Jutland. Acta Archaeologica 50, 1979, s. 173-208.

Nielsen, O. 1869 (udg.): Samling af Adkomster, Indtagtsangivelser og kirkelige Vedtcegter for Ribe Domkapitel og Bispestol nedskrevet 1290-1518 kaldet "Oldemoder" (Avia Ripensis). København.

Nyborg, E. 1979: Enkeltmænd og fællesskaber i organiseringen af det romanske sognekirkebyggeri. I: R. Egevang (red.): Strejflys over Danmarks bygningskultur. Festskrift til Harald Langberg. København, s. 37-64.

Nyborg 1986: Kirke - sognedannelse - bebyggelse. hikuin 12, s. 17-44

Näsman, U. 1991: Det syvende århundrede - et mørkt tidsrum i ny belysning. I: P. Mortensen \& B.M. Rasmussen (red.): Fra Stamme til Stat i Danmark, bd. 2. Højbjerg, s. 165-176.

Porskrog Rasmussen, C. 2013: Det Sønderjyske Landbrugs Historie 1544-1830. Aabenraa.

Poulsen, B. 2003a: Middelalderens fødsel - tiden 1000-1340 - avl og købstæder. I: L.S. Madsen \& O. Madsen (red.): Det sønderjyske landbrugs historie. Jernalder, vikingetid og middelalder. Haderslev, s. 458-492.

Poulsen, B. 2003b: Pest, krig, skat og stormflod - tiden 1340-1430. I: L.S. Madsen \& O. Madsen (red.): Det sønderjyske landbrugs historie. Jernalder, vikingetid og middelalder. Haderslev, s. 493-537.

Poulsen, B. \& S.M. Sindbæk 2011: Settlement and Lordship in Viking and Medieval Scandinavia. I: B. Poulsen \& S.M. Sindbæk (eds.): Settlement and Lordship in Viking and Early Medieval Scandinavia. Turnhout, s. 1-28.

Qvistgaard, S. 2010: Andrup - en bebyggelse fra ældre førromersk jernalder og germansk jernalder. Arkaologi i Slesvig - Archäologie in Schleswig 13, s. 9-17.

Siemen, P. 1990: Bebyggelseshistorie øst for Esbjerg - 3000 års landsbyer og enkeltgårde i Novrupområdet. Mark og Montre, s. 56-67.

Siemen, P. 1993: Mellem Uglvig og Tovrup - eller 3000 års bosættelser ved Grønnegård. Mark og Montre, s. 61-70. 
Siemen, P. 2000: Prestestien. Settlement from 4th-9th Century, vol. 1-2. Esbjerg.

Siemen, P. \& I. Stoumann 1996a: Hus, gård og landsby. I: V. Bruhn m.fl. (red.): Esbjerg Bys Historie 1. Esbjerg, s. 23-66.

Siemen, P. \& I. Stoumann 1996b: Grave og samfund. I: V. Bruhn m.fl. (red.): Esbjerg Bys Historie 1. Esbjerg, s. 103-158.

Skovgaard-Petersen, I. 1977: Oldtid og Vikingetid. I: A.E. Christensen m.fl. (red.): Danmarks historie. Bind 1. Tiden indtil 1340. København, s. 15-209.

Stoumann, I. 1980: Sædding. A Viking-age Village near Esbjerg. Acta Archaeologica 50, 1979, s. 95-118.

Svart Kristiansen, M. 2003: Arkæologiske undersøgelser af den middelalderlige landbebyggelse - metodiske problemer og prioriteringer i fortiden, nutiden og fremtiden. Bol og By 1-2, s. 9-29.

Søgaard, H. 1973: Ribe bispekrønike. Fra Ribe Amt, bind XVIII-II, s. 260-273.

Sørensen, A.B. 2002: Østergård - Undersøgelserne i 1998-1999. Arkcoologi i Slesvig, 8 (2000), s. 137-148.

Sørensen, A.B. 2003: Middelalderens fødsel - tiden 1000-1340 - huse, gårde og bebyggelser. I: L.S. Madsen \& O. Madsen (red.): Det sønderjyske landbrugs historie. Jernalder, vikingetid og middelalder, Haderslev, s. 434-457.

Sørensen, A.B. 2011: Østergaard. Vikingetid \& middelalder. Haderslev.

Søvsø, M. 2008: Stolpebyggede gårde fra renæssancen udgravet i Kærbøl ved Ribe. By, marsk og geest 20, s. 15-26.

Søvsø, M. 2009: Stolpebyggede gårde fra renæssancen udgravet i Kærbøl og Enderup ved Ribe. Arkcoologi i Slesvig - Archäologie in Schleswig 12, s. 225-233.

Søvsø, M. 2011: High Medieval Magnate Farms in Jutland with Particular Focus on the Region of Ribe. I: B. Poulsen \& S.M. Sindbæk (eds.): Settlement and lordship in Viking and early medieval Scandinavia. Turnhout, s. 119-135.

Søvsø, M. 2013: The Bishop of Ribe's rural property in Lustrup. Danish Journal of Archaeology, vol. 1, s. 4-26.

Søvsø, M. 2018: Detektorfund og bebyggelsesarkæologi - på markerne vest for Gl. Hviding kirke ved Ribe. I: V. Hilberg \& T. Lemm (red.): Viele Funde - grosse Bedeutung? Bericht des 33. Tverfaglige Vikingesymposiums. Kiel, s. 67-80.

Søvsø, M. 2019: Dankirke - nyt lys over centralpladsernes locus classicus. Arkceologi $i$ Slesvig - Archäologie in Schleswig 17, s. 65-82.

Trier Christiansen, T. 2018: Detektorfund og bebyggelsesudvikling ved Sdr. Tranders i det sydøstlige Aalborg - præsentation af en detektorplads og nogle udfordringer vedrørende tolkningen af detektorfundene. I: V. Hilberg \& T. Lemm (red.): Viele Funde - grosse Bedeutung? Bericht des 33. Tverfaglige Vikingesymposiums. Kiel, s. 109-124.

Vogt, H. 2017: From tribute to taxpaying: the changes in the understanding of private property in Denmark circa 1000-1250. Danish Journal of Archaeology, vol. 6, s. 85-92.

Weibull, L. 1911: Kritiska undersökningar i Nordens historia omkring år 1000. København.

Ørsnes, M. 1966: Form og stil i Sydskandinaviens yngre germanske jernalder. København.

\section{Web}

Slots- og Kulturstyrelsens arkæologiske strategi for jernalder:https://slks.dk/omraader/ kulturarv/arkaeologi-fortidsminder-og-diger/arkaeologi-paa-land/arkaeologiske-strate- 
gier/jernalder-aej-500-fkr-400-ekr-yj-400-800-ekr-vikingetid-800-1050-ekr/ (17. juni 2019)

Slots- og Kulturstyrelsens arkæologiske strategi for middelalder-landsbebyggelse: https:// slks.dk/omraader/kulturarv/arkaeologi-fortidsminder-og-diger/arkaeologi-paa-land/ arkaeologiske-strategier/middelalder-landbebyggelse-1050-1536-ekr/ (17. juni 2019)

Jordartskort:

https://www.geus.dk/produkter-ydelser-og-faciliteter/data-og-kort/danske-kort/download-jordartskort/ (17. juni 2019) 


\section{Freemen and villeins}

\section{A longue durée perspective on villages, farmsteads and social structure in western Jutland}

Over the course of the last two decades, Danish archaeology has seen a vast increase in excavation activity supported by the introduction of GIS-based systems. Moreover, the digital revolution has made accessible an extensive collection of historical maps, thereby enabling direct comparisons between excavated structures and depictions of the landscape extending back to the late 18th century.

The time-consuming process of building complete GIS-systems that include older excavations and reconstructing past landscapes from old maps is ongoing at most Danish museums. This has led to many intriguing correlations and insights. The current models for the settlement history in Denmark during the Iron Age and the Viking period are, however, still primarily based on the findings from the renowned Vorbasse excavations undertaken between 1974 and 1987, and only overviews of these results have been so far published.

This article is based on finds and evidence held at the Museum of Southwest Jutland and focuses on western Jutland. With a foundation in excavation results and landscape models extracted from the historical maps of c. 1800 , the aim is to apply a longue durée perspective in the search for the underlying structures constituting the agrarian landscape during the last two millennia.

The shifting climate appears to have had a profound impact, but written sources like the church list from Ribe diocese of c. AD 1325 give vital clues, which can be compared with the data emerging from the booming research into palaeoclimatic change (figs. 1-4).

Danish landscape laws written down in the 13th century distinguish between two types of agrarian settlement: the main village (adelby) and the thorp (torp). Thorps derived from main villages and were in some way subordinate to them. It is argued that this division may extend far back in the Iron Age, and a mapping of main villages has been attempted (figs. 5-7). Analysis of historical maps has shown that the arable areas cultivated in c. 1800 lie where the predecessors of the existing villages are to be found, extending all the way back to the Late Pre-Roman Iron Age. Finds recovered during metaldetector surveys are also found concentrated on this arable land. This indicates a direct continuity in the overall settlement pattern, the associated field systems and the growing community.

Based on cases from western Jutland, the settlement structure during the Iron Age and the Viking period is discussed. The excavated villages and farmsteads, their associated cemeteries and the numerous finds recovered by metal detector portray a society based on family-run farmsteads apparently without major class differences - very closely resembling the landscape depicted on historical maps 1000 years later (figs. 8-14).

Aristocratic sites or "central places" are also present in this area of southern Scandinavia, but they are few and far between.

The second part of the text deals with Medieval (in Denmark c. 1050-1550) villages and farmsteads. Based on excavated 
examples, it is argued that these are not yet as well understood as their predecessors since large parts of the Medieval remains are hidden underneath existing villages. The structural similarities between the Iron Age villages and their Early Modern counterparts portrayed on the historical maps indicate, however, that Medieval villages also followed the same overall trajectory (figs. 15-27).

The conclusion from the analysis is that village formation in western Jutland took place in the Late Pre-Roman Iron
Age. Climate- and disease-related events, like the volcanic dust cloud after AD 536 and the Black Death in 1350, appear to be traceable as hiatuses in the archaeological record, but the overall trend is one of continuity. Every village that existed around 1800 seems to have had predecessors going all the way back to the Iron Age. The number of farms in an individual village also seems to have been roughly the same through the ages, indicating that shared ideas about sustainability may, in one form or another, have determined this.

Morten Søusø Sydvestjyske Museer 